\title{
The Job Satisfaction of the Ministry of National Education Personnel (The Case of a General Directorate) Neslihan KILIÇ*a
}

\begin{tabular}{l} 
Article Info \\
\hline DOI: $10.14686 /$ buefad.418294 \\
\hline Article History: \\
Received 24.04.2018 \\
Accepted $\quad 08.10 .2018$ \\
Published $\quad 31.10 .2018$ \\
\hline Keywords: \\
Job satisfaction, \\
Personnel, \\
Motivation. \\
\hline Article Type: \\
Research article \\
\end{tabular}

\begin{abstract}
Workers' conditions in the workplace, motivation and reactions to the existing situations are closely related to their job satisfaction. The general purpose of the current study is to investigate the Ministry of Nation Education (MEB) personnel's job satisfaction. The population of the study is comprised of 166 personnel working in a general directorate of MEB. All of the population was reached to collect data. As the data collection tool, "The White-Collar Workers' Job Satisfaction Scale" developed by Ünsal and Özalp Türetgen (2005) was used. The findings of the research have revealed that the workers find their jobs monotonous, have negative opinions about their jobs in terms of their compliance with their abilities and their status in the society, think that there is disturbing noise in their workplace, find their wages inadequate, think that their superiors generally discriminate against some workers, do not find their work environments enjoyable and some of them are of the opinion that workers experience problems with their superiors. A considerable number of the workers stated that there is a lack of communication with their colleagues. For most of the questions, a considerable number of the workers avoided giving response.
\end{abstract}

\section{Millî Eğitim Bakanlığı Personelinin İş Doyumu (Bir Genel Müdürlük Örneği)}

\begin{tabular}{|c|c|}
\hline \multicolumn{2}{|c|}{ Makale Bilgisi } \\
\hline \multicolumn{2}{|c|}{ DOI:10.14686/buefad.418294 } \\
\hline \multicolumn{2}{|c|}{ Makale Geçmiși: } \\
\hline Geliş & 24.04 .2018 \\
\hline Kabul & 08.10 .2018 \\
\hline Yayın & 31.10 .2018 \\
\hline $\begin{array}{l}\text { Anahta } \\
\text { İş̧ } \\
\text { doyum }\end{array}$ & meler: \\
\hline
\end{tabular}

Makale Türü:

Araştırma makalesi

\section{$\ddot{O ̈ z}$}

Bireyin iş yerinde olumlu çalışma koşullarına sahip oluşu, motivasyonu ve bu durumlara olan tepkisi iş doyumu ile ifade edilmektedir. Bu araştırmanın genel amacı Millî Eğitim Bakanlığı(MEB) personelinin iş doyumu özelliklerini belirlemektir. Çalışma evrenini MEB'e bağlı bir genel müdürlükte çalışan 166 kişi oluşturmaktadır. Çalışma evreninin tamamına ulaşılmışıı. Araştırmada veri toplama aracı olarak Ünsal ve Özalp Türetgen (2005) tarafından geliştirilen "Beyaz Yakalı Çalışanlar İçin İş Doyumu Ölçeği” ölçeği kullanılmıştır. Araştırma bulgularına göre çalışanlar işlerini monoton bulmakta, yaptıkları işin yeteneklerine uygunluğu ve toplumdaki saygınlığı konusunda genelde olumsuz düşüncelere sahip olmakta, işyerlerinde rahatsız edici düzeyde gürültü olduğunu belirtmekte, ücretlerini yetersiz bulmakta, genellikle üstlerinin çalışanlar arası ayrımcılık yaptığını, çoğunlukla iş ortamlarını eğlenceli bulmadıklarını, çalışanların bir bölümü ise üstleri ile iletişimde problem yaşadıklarını belirtmektedir. Çalışanların dikkate değer bir bölümü iş arkadaşları ile çalışma ortamlarında iletişim kopukluğu yaşadıklarını belirtmiştir. Araştırma sorularının çoğunda neredeyse üçte birlik bir kesim çalışan sorulara yanıt vermekten kaçınmıştır.

*Corresponding Author: neslihankilic82@ hotmail.com

${ }^{\mathrm{a}}$ Teacher, Ministry of National Education, Ankara/Turkey, http://orchid.org/0000-0003-4696-4780 


\section{Introduction}

The profession defined as the job having specific rules and done on the basis of the acquired systematic knowledge and skills to produce goods or services useful for people in return for money is one of the most important choices in the lives of humans and the occupation on which humans spend the most time. While performing this occupation occupying a large part of human life, people are absolutely in need of motivation and happiness. If the needs motivating the individual in work life can be understood well, healthy working conditions can be created in every sense by taking the advantages of these needs. Healthy working conditions are also important for both the employee and the organization. There are many factors that can affect the motivation in the work place such as the morale of the staff, working in harmony with managers, working in harmony with colleagues, meeting the expectations of workers, working conditions of the workplace, objective managerial approaches, and appreciation of successes. Motivation is the directing, mobilizing and activating power of the internal energy towards a certain target (Düren, 2000, p. 4). According to Akat (1984, p. 175), it is the sum of the efforts expended to continuously move an individual or individuals towards a certain direction.

Workers' conditions in their workplaces, motivation and their reactions to the existing situations are closely related to their job satisfaction. The concept of job satisfaction relates to the internal reaction of employees to their jobs. Job satisfaction is defined in different ways. Job satisfaction; "The individual's appreciating his/her job and job-related life as a satisfying situation resulting in positive feelings" (Çetinkanat, 2000). Job satisfaction is an emotional reaction to the state of job. Therefore, it is invisible but perceptible. Job satisfaction usually depends on the extent to which outcomes meet or exceed expectations.

According to another definition of job satisfaction, job satisfaction captures the individual's attitude towards and general feelings and opinions about his/her job and workplace (Miner, 1992, p. 116). People's being content with their job is considered to be satisfaction but not being content with it is considered to be dissatisfaction (Spector, 1997, p. 6). A great deal of research focuses on the issues of job satisfaction and burn-out in the fields of organization, organizational psychology and administration. Stress not only causes many health problems but also lack of job satisfaction and motivation in workers. While trying to cope with stress, individuals experience many negative feelings such as anger, sadness, fear or produce symptoms indicating inability of coping with stress (Smith, Jaffe-Gill \& Seggl, 2009).

In the literature, the theories related to job satisfaction are also called the theories of motivation. Motivation has a power to direct an individual towards a certain target. This power can be internal (cognitive) or external (environmental) (Bilgin, 2003, p. 248). One of the theories of motivation is the Herzberg theory. According to this theory, factors in the workplace determine satisfaction or dissatisfaction. These factors can be internal or external. Internal factors can be the individual's personality characteristics, structure of the job and the individual's success status (Judge, Parker, Colbert, Heler, ve Ilies 2001). External factors on the other hand can be bad working conditions, lack of hygiene, low wages and unmet security needs. If external factors are positive, they do not affect motivation; yet, prevent job dissatisfaction (Northcraft and Neale, 1990, p. 139). McClelland, one of the psychological modernization theorists, states that the individual has three basic needs that are affiliation needs, power needs and achievement needs. Of these three basic needs, the achievements needs most strongly affect the individual and society (Eren, 2008, p. 522).

It causes job dissatisfaction in the absence of the individual's achivement needs. According to Keser (2005), dissatisfaction in the workplace can result in absenteeism, poor performance and general dissatisfaction with life. Dissatisfaction in the workplace may lead to burn-out and burn-out in turn results in decreasing personal accomplishment, depersonalization and emotional exhaustion thus causing undesired outcomes (Maslach and Jackson, 1981). Job satisfaction is a concept that is of great importance for workers to continue their professional lives (Pillay, Goddard and Wilss, 2005). It was stated that when workers are not content with their job performance, they become suspicious of their self-efficacy (Brouwers, Evers and Tomic, 2001).

Theories of motivation, gathered under the name of Process Theories, deal with how people are motivated. Process Theories are Classical Conditioning, Expectation Theory and Equality and Objective Theory. Theory of Equality and Objective put forward by O. Stacy Adams after his motivation works in General Electric. According to this theory, individuals generally attach importance to the concepts of equality and justice and they want to be treated on the basis of these concepts. The worker sees what he/she consumes as inputs and sees what he/she obtains as a result of these efforts as outcomes, then he/she makes a calculation. If the worker comes to 
the conclusion that inputs are more than outputs, then he/she might believe he/she cannot receive what he/she deserves. In this case, his/her job satisfaction is expected to decrease. Moreover, if the worker is of the opinion that his/her problems are not fairly handled and solved, then his/her job satisfaction and commitment decrease (Perry, 1993; Eren, 2008; Keskin, Akgün and Günsel, 2008; Bilgin, 2003).

What determines the worker's behaviors in the workplace is his/her job-related attitudes and these attitudes are shaped by the combined effect of many factors such as authority granted to workers, tolerance to mistakes, clarity of decisions, workers' participating in decision-making process and positive working conditions (Pascoe, Ali and Warne, 2002; cited in Ertürk and Keçelioğlu, 2012). Competitive environments, globalization and speed of technological development put pressure on institutions and employees. One of the factors that can alleviate this pressure is job satisfaction. Individuals who cannot achieve job satisfaction can produce different reactions depending on their personal development, personality characteristics and administrative system of the organization and the most common reactions in this regard are absenteeism, focusing more on personal works rather than occupational responsibilities, prolonged breaks, violation of rules and exhibition of aggressive behaviors (Sun, 2002).

The inability of employees to reach job satisfaction can lead to burn-out. The concept of burn-out first introduced by Maslach and Jackson (1986) has been observed more intensely in the professions dealing with people. Burn-out is a result of intense stress, alienation to the job, continuous hopelessness, the idea that the individual cannot make any difference in his/her job, dissatisfaction, exhaustion of living energy and the desire to give up and obligation to obey (Barutçu and Serinkan, 2008; Kaçmaz, 2005). According to Maslach, burn-out can be addressed under three dimensions that are emotional exhaustion, depersonalization and decreasing personal accomplishment (Ergin, 1992). Emotional exhaustion can be considered the first stage of burn-out. In this stage, the worker feels lack of energy, reluctant and incompetent. Within the context of the dimension of depersonalization, the worker perceives people and his/her colleagues as objects rather than individuals and may adopt negative, sarcastic and rigid attitudes towards them. The dimension of decreasing personal accomplishment is related to feeling of inefficiency, regarding oneself unsuccessful, downheartedness, and avoidance of interaction with people (Maslach and Jackson, 1981; Kurçer, 2005).

In light of the related literature, it can be argued that the job satisfaction levels of teachers and MEB personnel can somehow be regarded as an important indicator of their burn-out levels, work-related achievements and performance. There is a great deal of national and international research conducted on the concepts of motivation, burn-out and job satisfaction (Eryllmaz, 1987; Kinman \& Kinman, 2001; Türe, 1993; Sabanc1, 1994; Çetinkanat, 2000; Kuruoglu, 1995; Sancar, 1996; Rowley, 1996; Özsüer, 2016). Sabanc1 (1994) concluded that reciprocal communication is of great importance for both managees and managers; moreover, it significantly affects workers' job satisfaction and motivation. In a study by Rowley (1996) called "Motivation and Academic Staff in Higher Education", it was found that the variables most strongly affecting motivation are economic rewards, learning culture and higher education, the experience of personnel and diversity of roles, personal autonomy and organizational culture. Job satisfaction is an important concept that concerns workers' job-related psychological health. Some research on the other hand has revealed that gender is not an important variable in terms of job satisfaction and that men and women have similar job satisfaction characteristics (Sağır, 2016; Kılıç, 2011; Tüzemen, 2004; Çekiç, 2017). Some other research focusing on the relationship between length of service and job satisfaction reported that with increasing length of service, job satisfaction decreases (Acar, 2016). Demographic variables such as age, gender, marital status, length of service and level of education are related to the job satisfaction and motivation of the teachers and they play an important role on motivation (Bogler, 2002).

When the relevant literature is reviewed, it is seen that research has been made in various sectors including the education sector and accordingly teachers and school administrators. However, there is not enough research focusing on the central organization of MEB. In addition, it is thought that gender and length of service are important indicators in job satisfaction and it will be useful to examine the job satisfaction of the personnel of Ministry of National Education in terms of these variables if the studies and results related to job satisfaction are taken into consideration. The Ministry of National Education (MEB) is the main authority organizing and determining the direction of education. Thus, the importance attached to its personnel by MEB, working conditions provided for them and their motivation naturally become important. Determination of the job satisfaction levels of the personnel working in the central organization of MEB is believed to be important for both revelation of the existing state and its effect on the job satisfaction levels of the personnel working in the 
peripheral organizations of MEB. Thus, the current study aims to explore the job satisfaction levels of the MEB personnel and to produce important data that can provide some guidance to the literature and the administrators of the Ministry.

\section{Purpose of the Study}

The general purpose of the current research is to determine the job satisfaction of MEB personnel. To this end, answers to the following questions were sought.

1. What is the job-satisfaction level of the participating personnel?

2. Is there a significant correlation between their gender and job satisfaction level?

3. Is there a significant correlation between their length of service and job satisfaction level?

\section{Limitations}

The results of the current study are limited to the opinions of the personnel working in a directorate of MEB and participating in the current study.

\section{Method}

\section{Research Model}

The study was designed on the basis of the survey model. The survey model is used to collect the data required to determine the various characteristics of a group. The main advantage of this model is that it allows the collection of the required information about the various characteristics of participants (Büyüköztürk, Çakmak, Akgün, Karadeniz, and Demirel, 2010, p. 16-17). In this regard, the survey model was employed in the current study to determine whether the personnel's job satisfaction levels vary significantly depending on the independent variables of gender, title in the workplace, the general directorate where they are working, length of service and the last school graduated.

\section{Study Population and Sampling}

The population of the study is comprised of the personnel of a general directorate of MEB. As all the people in the population participated in the study, sampling was not selected and the study was conducted on the population. In the population of the study, there are a total of 166 participants.

\section{Data Collection Tool}

In the current study, as the data collection tool, the "White Collar Workers' Job Satisfaction Scale" developed by Ünsal and Özalp Türetgen (2005) was used. To summarize the characteristics of the first sample group in which the scale is developed, the sample group is composed of 694 white-collar workers working in different sectors and in different businesses. Participants from both the government and the public sector work in a variety of fields, such as production, service, education, finance, and healthcare. $58.1 \%$ of the participants were female, $41.9 \%$ were male. When the age distributions of the sample group were examined, $19.2 \%$ of participants were under 25 years old, $50.5 \%$ between $25-34$ years, $21.4 \%$ between $35-44$ years, $8.9 \% 45$ years. $20.8 \%$ of the sample group is in secondary education, $60.3 \%$ is in higher education and $18.9 \%$ is in graduate education. In addition, $54.9 \%$ of participants were married, $41.2 \%$ were single and $3.9 \%$ were separated from their partners.

The scale has 35 items and 4 dimensions. These dimensions are: 1) Administrative policies and applications, 2) Sructure of the job, 3) Communication and relationships, 4) Physical working conditions. The results of Exploratory Factor Analysis (EFA) revealed that the factor loading vary between 0.37 and 0.74 . The Cronbach alpha reliability coefficient for the whole scale was calculated to be 0.89 , the coefficients for the sub-dimensions are as follows; 0.88 for the first dimension, 0.75 for the second dimension, 0.67 for the third dimension and 0.66 for the fourth dimension. Scale is prepared in the form of a classified scale like $3=$ Yes, $2=$ Partially, $1=$ No. Participants' job satisfaction levels are interpreted according to the frequency ratios in these categories.

\section{Data Analysis}

In the statistical analysis of the data, a computer software program (SPSS) was used. 
The frequency and percentage ratios of the characteristics of the independent variables such as gender, title in the workplace, length of service and last graduated school of the participating personnel were resolved. From the independent variables, the gender and length of service were tested by a quasi-square analysis to see whether they were a significant variable in terms of job satisfaction. Because it is more appropriate for the type of job satisfaction scale used in the research, it has been analyzed in case of comparative analysis according to the independent variables, where the use conditions of the rent square are satisfied. The reason for the use of squared for each item of the scale is that it is based on the idea that, in terms of job satisfaction, each item in the measure can have its own distinct meaning, and that it can give a different perspective to the findings of the research.

\section{Findings}

The findings obtained as a result of the study were interpreted in relation to the sub-problems.

\section{Demographic Features}

The demographic features of the participants are presented in Table 1.

Table 1. Participants’ Demographic Features

\begin{tabular}{|c|c|c|}
\hline Demographic Features & f & $\%$ \\
\hline \multicolumn{3}{|l|}{ Gender } \\
\hline Female & 92 & 55,4 \\
\hline Male & 74 & 44,6 \\
\hline Total & 166 & 100,0 \\
\hline \multicolumn{3}{|l|}{ Length of service } \\
\hline $1-10$ years & 37 & 22,3 \\
\hline $11-20$ years & 67 & 40,4 \\
\hline 21 years or more & 62 & 37,3 \\
\hline Total & 166 & 100,0 \\
\hline \multicolumn{3}{|l|}{ The last school graduated } \\
\hline Lower than university (Elementary-middle, high school and associate's degree) & 19 & 11,4 \\
\hline Undergraduate & 100 & 60,2 \\
\hline Postgraduate (MA-PhD) & 47 & 28,3 \\
\hline Total & 166 & 100,0 \\
\hline \multicolumn{3}{|l|}{ Title } \\
\hline Administrators, ME Specialists and Assistant Specialists & 21 & 12,7 \\
\hline Teachers & 101 & 60,8 \\
\hline General Administrative Services Personnel and Others & 44 & 26,5 \\
\hline Total & 166 & 100,0 \\
\hline
\end{tabular}

Of the total participating 166 personnel from the same general directorate, $55.4 \%$ are females and $44.6 \%$ are males. When the participants were evaluated in terms of their length of service, it was found that $40.4 \%$ of them have been working for 11-20 years; $37.3 \%$ have been working for 21 years or more; $22.3 \%$ have been working for 1-10 years. When the participants were evaluated in terms of the last school graduated, it was found that $60.2 \%$ of them hold a BA degree; $28.3 \%$ hold a postgraduate degree (MA or PhD) and $11.4 \%$ hold a degree lower than an undergraduate degree (elementary-middle-high school- associate's degree). When the data related 
to the titles of the participants were examined, it was found that $60.8 \%$ of them are teachers; $26.5 \%$ are general administrative service personnel and others; $12.7 \%$ of them are specialists and assistant specialists. When the demographic features of the participants are generally evaluated, it is seen that majority of the participants are females, high majority of them have been working for 11-20 years and high majority of them are university graduates and most of them are teachers.

\section{Job satisfaction characteristics of the personnel}

The participating personnel's job satisfaction characteristics were analyzed and the findings are presented in Table 2.

Table 2. Participants' Job Satisfaction Characteristics

\begin{tabular}{lllllllll}
\hline No* & Items & & 3 & & & \\
\hline & & f & $\%$ & f & $\%$ & f & $\%$
\end{tabular}

\section{Structure of the Job}

2 I cannot use my creativity in my job as I wish.

My job offers diversity as it includes different tasks to be completed.

12 I am working in a job suitable for my competences.

17 My job is monotonous.

While doing my job, I can make my own decisions and implement them.

26 The contribution of my job to my personal development is negative.

31 If I had enough money, I would quit this job.

34 My job has a prestigious status in the society.

\section{Physical Working Conditions}

1 Meals offered by my workplace are satisfying.

Security measures taken in my workplace (entrance and exit security, fire, etc.) are adequate.

The wage I receive in my job (including premiums and bonuses) is satisfying.

15 There is disturbing noise in my workplace.

20 In my workplace, the materials I need for my job are immediately provided.

25 A great care is taken for hygiene in my workplace.

$\begin{array}{lccccc}68 & 41,0 & 45 & 27,1 & 53 & 31,9 \\ 135 & 81,3 & 9 & 5,4 & 22 & 13,3 \\ 97 & 58,4 & 42 & 25,3 & 27 & 16,3 \\ 92 & 55,4 & 31 & 18,7 & 43 & 25,9 \\ 45 & 27,1 & 49 & 29,5 & 72 & 43,4 \\ & & & & & \\ 119 & 71,7 & 36 & 21,7 & 11 & 6,6 \\ 59 & 35,5 & 63 & 38,0 & 44 & 26,5 \\ 100 & 60,2 & 54 & 32,5 & 12 & 7,2\end{array}$

12

$6,6 \quad 33$

19,9

109

65,7

33

$19,9 \quad 24$

14,5

6

38,6

22

$13,3 \quad 80$

48,2

117

70,5

88

53,0

45

27,1

33

19,9

11
69,9 
30 Lighting is enough in my workplace.

$\begin{array}{llllll}130 & 78,3 & 25 & 15,1 & 11 & 6,6\end{array}$

\section{Administrative Policies and Applications}

3 In my workplace, promotion system is transparent and just.

$\begin{array}{llllll}34 & 20,5 & 64 & 38,6 & 68 & 41,0 \\ 49 & 29,5 & 66 & 39,8 & 51 & 30,7 \\ 93 & 56,0 & 42 & 25,3 & 31 & 18,7 \\ 63 & 38,0 & 64 & 38,6 & 39 & 23,5 \\ & & & & & \\ 88 & 53,0 & 50 & 30,1 & 28 & 16,9\end{array}$

In my workplace, my supervisors discriminate between workers.

In my workplace, desired and undesired behaviors have been clearly defined.

$\begin{array}{llllll}74 & 44,6 & 61 & 36,7 & 31 & 18,7\end{array}$

18 My workplace encourages the establishment of open, transparent and trust-based relationships.

$\begin{array}{llllll}73 & 44,0 & 67 & 40,4 & 26 & 15,7\end{array}$

21 I would recommend my friends to work in this workplace.

$\begin{array}{llllll}87 & 52,4 & 57 & 34,3 & 22 & 13,3\end{array}$

23 My offers for the improvement of my work are taken into consideration.

$84 \quad 50,6 \quad 63 \quad 38,0 \quad 19 \quad 11,4$

$\begin{array}{llllll}87 & 52,4 & 60 & 36,1 & 19 & 11,4\end{array}$

In my workplace, objectives are clear, precise and well-defined.

$76=05,8=59=35,5=31$

18,7

29 My organization abstains from firing good workers.

76

$45,8 \quad 59 \quad 35,5 \quad 31$

32 In my workplace, working environment is generally enjoyable.

$\begin{array}{llllll}66 & 39,8 & 56 & 33,7 & 44 & 26,5\end{array}$

35 I think workers are valued in my workplace.

$\begin{array}{llllll}79 & 47,6 & 55 & 33,1 & 32 & 19,3\end{array}$

\section{Communication and Relationships}

$4 \quad$ I know what I should do in my job.

$\begin{array}{rrrrrr}129 & 77,7 & 26 & 15,7 & 11 & 6,6 \\ 144 & 86,7 & 19 & 11,4 & 3 & 1,8 \\ 130 & 78,3 & 28 & 16,9 & 8 & 4,8 \\ 129 & 77,7 & 28 & 16,9 & 9 & 5,4\end{array}$

19 I experience difficulty in solving my problems with

My relationships with my supervisors are problematic.

14 I am content with my relationships with my colleagues.

129

$\begin{array}{lllll}77,7 & 28 & 16,9 & 9 & 5,4\end{array}$ 
my colleagues.

24

28$$
\begin{aligned}
& \text { I can easily tell } \\
& \text { my superiors }
\end{aligned}
$$

While doing my job, I have lack of communication with other workers. problems I encounter while working.
I can have help from my colleagues in solving

$$
84,3
$$

73,5

32

19,3

12

112

$67,5 \quad 34 \quad 20,5 \quad 20$

*Item numbers are their numbers in the scale.

The findings related to the job satisfaction characteristics of the personnel working in the general directorate are summarized considering the sub-dimensions of the scale below.

\section{Structure of the Job}

Of the participating personnel, $81.3 \%$ stated that their jobs require them to engage in different duties; $60.2 \%$ of them think that their jobs have a prestigious position in the society. The percentage of those stating that they are working in a job suitable for their competences is 58.4 while the percentage of those finding their job monotonous is 55.4. Nearly two fifths of the participants $(41 \%)$ stated that they can use their creativity in their jobs; $43.4 \%$ stated that they cannot make their own decisions and implement them; $38 \%$ stated that they are undecided whether to quit their job if they had enough money. When a general evaluation is made, it can be said that though majority of the workers think that they can use their creativity in their jobs, their jobs have a prestigious position in the society and they work in a job in harmony with their competences, nearly one third have negative opinions about the position of their jobs in the society and compliance of their jobs with their competences. Moreover, most of the workers cannot make their own decisions and implement them and find their jobs monotonous.

\section{Physical Working Conditions}

Of the participants, $73.5 \%$ find the meals offered in their workplace satisfying, $65.7 \%$ think that the security measures taken in their workplace are adequate; $70.5 \%$ think that the level of the noise in their workplace is disturbing. Moreover, nearly two thirds of the workers (69.9\%) are of the opinion that enough care is taken for hygiene in their workplace, $78.3 \%$ find the lighting conditions adequate. The percentage of those finding their wage satisfying is 48.2 and more than half of them (53\%) think that the materials they need for their jobs are immediately provided. When a general evaluation is made, it can be said that the workers have positive opinions in general about meals, security measures and hygiene and lighting; yet, they have negative opinions about the noise in their workplace. More than half of the workers also seem to be not satisfied with their wages.

\section{Administrative Policies and Applications}

Of the participants, $41 \%$ think that the promotion system in their workplace is transparent and just and $30.7 \%$ of them think that they are not objectively assessed in their workplace. The percentage of those finding their workplace enjoyable is $39.8 \%$. More than half of the workers $(53 \%)$ think that their superiors discriminate between them. And again more than half of the participants $(56 \%)$ stated that they receive constructive feedback related to their jobs. The percentage of those not responding to the item concerning whether they are appreciated orally or in writing in their workplace is $38.6 \%$, while $38 \%$ stated that they are appreciated. The percentage of the participants thinking that desired and undesired behaviors in the workplace are clearly defined is 44.6. The percentage of the participants thinking that the administration needs to encourage the establishment of transparent, open and trust-based relationships is 44 . Of the participants, $47.6 \%$ stated that workers are valued in their workplace. More than half of the workers (52.4\%) stated that they would recommend their workplace to their friends to work. The percentage of the workers stating that their suggestions related to their jobs are taken into consideration is 52.4. When a general evaluation is made, it can be said that there is no transparent and just promotion system in their workplace; the workers are not objectively assessed; superiors discriminate between workers and they do not find their working environments enjoyable. In addition to these, the workers in general 
have positive opinions about receiving constructive feedback, working in this workplace and consideration of their suggestions about their jobs. Yet, the percentages of the participants not responding to many items are high.

\section{Communication and Relationships}

Of the participants, $77.7 \%$ stated that they know what they should do in their jobs and $78.3 \%$ stated that they are content with their relationships with their colleagues. Moreover, $84.3 \%$ of the participants stated that they can receive help from their colleagues for the problems they encounter in their workplace and $73.5 \%$ stated that they can easily tell the problems they experience in their jobs to their superiors. The percentage of the participants stating that their relationships with their superiors are problematic is 86.7 and the percentage of those experiencing difficulties in solving their problems with their colleagues is 77.7. Furthermore, $67.5 \%$ of the participants think that they experience lack of communication with other workers. When a general evaluation is made, it can be said that the workers know what they should do in their jobs, they are content with their relationships with their colleagues, they can receive help from their colleagues to solve their problems and they can easily talk about their problems with their superiors. On the other hand, the workers in general have problematic relationships with their superiors and they experience lack of communication with other workers.

The participants' job satisfaction characteristics were compared according to the gender variable and the results are presented in Table 3.

Table 3. Participants' Job Satisfaction Characteristics according to Gender

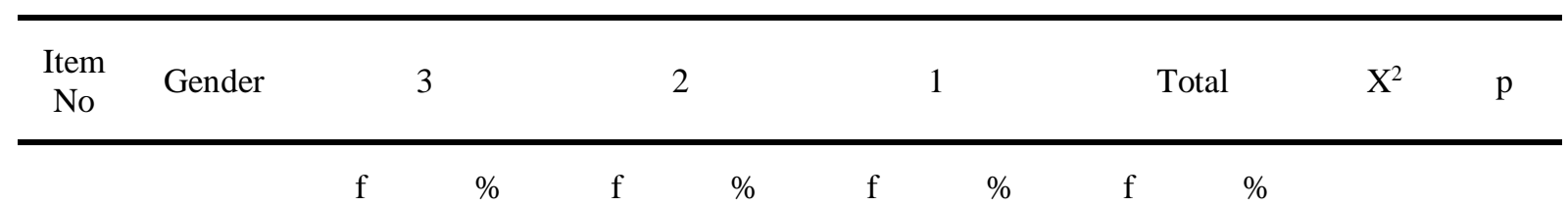

Structure of the job

\begin{tabular}{|c|c|c|c|c|c|c|c|c|c|c|c|}
\hline \multirow{2}{*}{2} & Female & 39 & 42,4 & 21 & 22,8 & 32 & 34,8 & 92 & 100,0 & \multirow{2}{*}{2,026} & \multirow{2}{*}{$\begin{array}{c}0,36 \\
3\end{array}$} \\
\hline & Male & 29 & 39,2 & 24 & 32,4 & 21 & 28,4 & 74 & 100,0 & & \\
\hline \multirow{2}{*}{7} & Female & 74 & 80,4 & 4 & 4,3 & 14 & 15,2 & 92 & 100,0 & \multirow{2}{*}{1,060} & 0,58 \\
\hline & Male & 61 & 82,4 & 5 & 6,8 & 8 & 10,8 & 74 & 100,0 & & 9 \\
\hline \multirow{2}{*}{12} & Female & 55 & 59,8 & 23 & 25,0 & 14 & 15,2 & 92 & 100,0 & \multirow{2}{*}{0,211} & 0,90 \\
\hline & Male & 42 & 56,8 & 19 & 25,7 & 13 & 17,6 & 74 & 100,0 & & 0 \\
\hline \multirow{2}{*}{17} & Female & 49 & 53,3 & 17 & 18,5 & 26 & 28,3 & 92 & 100,0 & \multirow{2}{*}{0,621} & 0,73 \\
\hline & Male & 43 & 58,1 & 14 & 18,9 & 17 & 23,0 & 74 & 100,0 & & 3 \\
\hline \multirow{2}{*}{22} & Female & 20 & 21,7 & 26 & 28,3 & 46 & 50,0 & 92 & 100,0 & \multirow{2}{*}{4,395} & \multirow{2}{*}{$\begin{array}{c}0,11 \\
1\end{array}$} \\
\hline & Male & 25 & 33,8 & 23 & 31,1 & 26 & 35,1 & 74 & 100,0 & & \\
\hline \multirow{2}{*}{26} & Female & 65 & 70,7 & 22 & 23,9 & 5 & 5,4 & 92 & 100,0 & \multirow{2}{*}{0,945} & \multirow{2}{*}{$\begin{array}{c}0,62 \\
4\end{array}$} \\
\hline & Male & 54 & 73,0 & 14 & 18,9 & 6 & 8,1 & 74 & 100,0 & & \\
\hline 31 & Female & 31 & 33,7 & 36 & 39,1 & 25 & 27,2 & 92 & 100,0 & 0,308 & 0,85 \\
\hline
\end{tabular}




\begin{tabular}{|c|c|c|c|c|c|c|c|c|c|c|}
\hline Male & 28 & 37,8 & 27 & 36,5 & 19 & 25,7 & 74 & 100,0 & & 7 \\
\hline Female & 54 & 58,7 & 34 & 37,0 & 4 & 4,3 & 92 & 100,0 & \multirow{2}{*}{3,695} & 0,15 \\
\hline Male & 46 & 62,2 & 20 & 27,0 & 8 & 10,8 & 74 & 100,0 & & \\
\hline
\end{tabular}

\section{Physical Working Conditions}

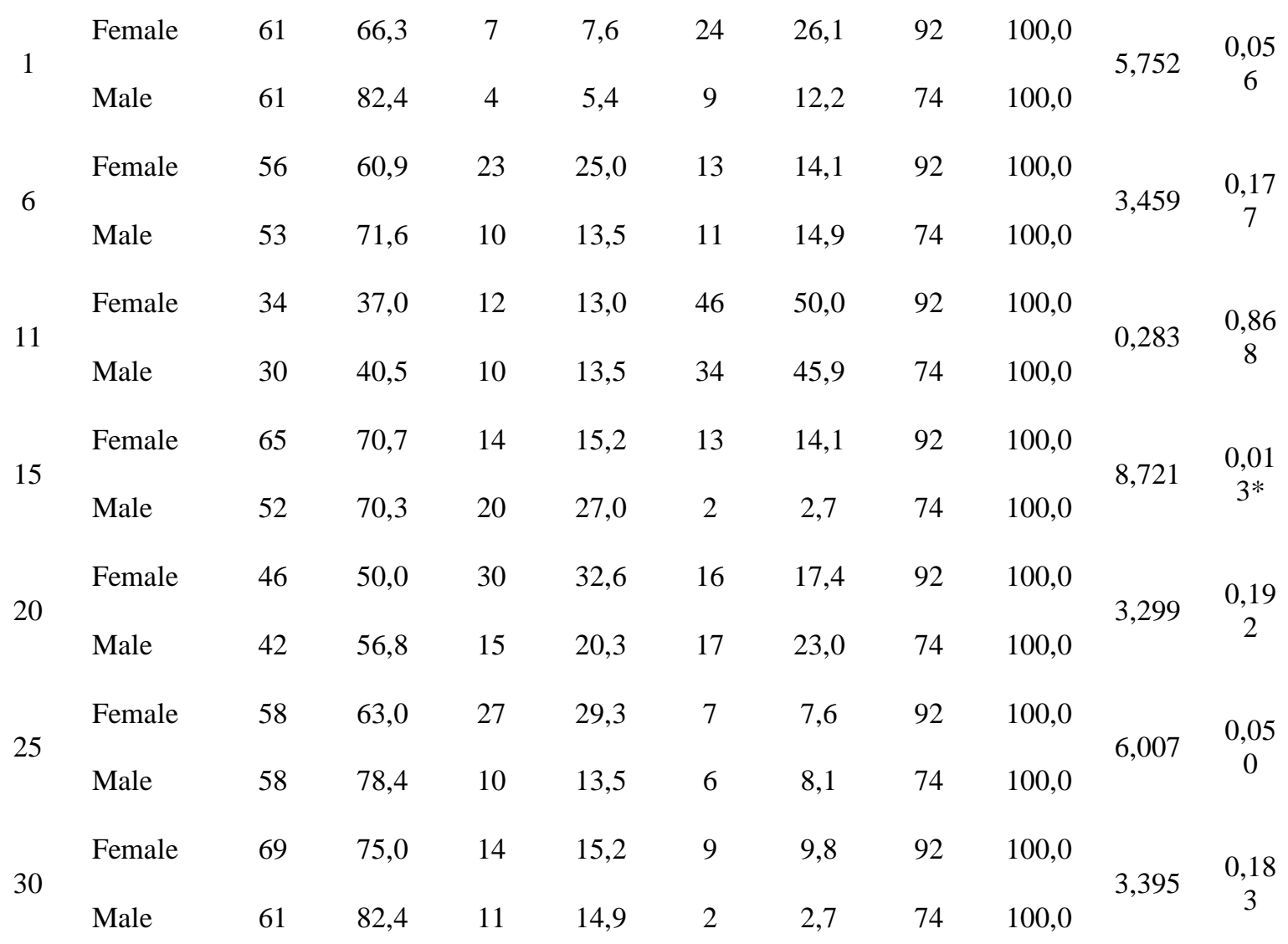

\section{Administrative Policies and Applications}

\begin{tabular}{|c|c|c|c|c|c|c|c|c|c|c|c|}
\hline \multirow{2}{*}{3} & Female & 21 & 22,8 & 33 & 35,9 & 38 & 41,3 & 92 & 100,0 & \multirow{2}{*}{0,945} & \multirow{2}{*}{$\begin{array}{c}0,62 \\
3\end{array}$} \\
\hline & Male & 13 & 17,6 & 31 & 41,9 & 30 & 40,5 & 74 & 100,0 & & \\
\hline \multirow{2}{*}{5} & Female & 27 & 29,3 & 37 & 40,2 & 28 & 30,4 & 92 & 100,0 & \multirow{2}{*}{0,019} & \multirow{2}{*}{$\begin{array}{c}0,99 \\
1\end{array}$} \\
\hline & Male & 22 & 29,7 & 29 & 39,2 & 23 & 31,1 & 74 & 100,0 & & \\
\hline \multirow{2}{*}{8} & Female & 50 & 54,3 & 25 & 27,2 & 17 & 18,5 & 92 & 100,0 & \multirow{2}{*}{0,394} & \multirow{2}{*}{$\begin{array}{c}0,82 \\
1\end{array}$} \\
\hline & Male & 43 & 58,1 & 17 & 23,0 & 14 & 18,9 & 74 & 100,0 & & \\
\hline 10 & Female & 36 & 39,1 & 35 & 38,0 & 21 & 22,8 & 92 & 100,0 & 0,129 & 0,93 \\
\hline
\end{tabular}




\begin{tabular}{|c|c|c|c|c|c|c|c|c|c|c|c|}
\hline & Male & 27 & 36,5 & 29 & 39,2 & 18 & 24,3 & 74 & 100,0 & & 8 \\
\hline \multirow{2}{*}{13} & Female & 47 & 51,1 & 33 & 35,9 & 12 & 13,0 & 92 & 100,0 & \multirow{2}{*}{4,198} & \multirow{2}{*}{$\begin{array}{c}0,12 \\
3\end{array}$} \\
\hline & Male & 41 & 55,4 & 17 & 23,0 & 16 & 21,6 & 74 & 100,0 & & \\
\hline \multirow{2}{*}{16} & Female & 40 & 43,5 & 36 & 39,1 & 16 & 17,4 & 92 & 100,0 & \multirow{2}{*}{0,557} & \multirow{2}{*}{$\begin{array}{c}0,75 \\
7\end{array}$} \\
\hline & Male & 34 & 45,9 & 25 & 33,8 & 15 & 20,3 & 74 & 100,0 & & \\
\hline \multirow{2}{*}{18} & Female & 38 & 41,3 & 37 & 40,2 & 17 & 18,5 & 92 & 100,0 & \multirow{2}{*}{1,381} & \multirow{2}{*}{$\begin{array}{c}0,50 \\
1\end{array}$} \\
\hline & Male & 35 & 47,3 & 30 & 40,5 & 9 & 12,2 & 74 & 100,0 & & \\
\hline \multirow{2}{*}{21} & Female & 47 & 51,1 & 34 & 37,0 & 11 & 12,0 & 92 & 100,0 & \multirow{2}{*}{0,743} & \multirow{2}{*}{$\begin{array}{c}0,69 \\
0\end{array}$} \\
\hline & Male & 40 & 54,1 & 23 & 31,1 & 11 & 14,9 & 74 & 100,0 & & \\
\hline \multirow{2}{*}{23} & Female & 43 & 46,7 & 38 & 41,3 & 11 & 12,0 & 92 & 100,0 & \multirow{2}{*}{1,267} & \multirow{2}{*}{$\begin{array}{c}0,53 \\
1\end{array}$} \\
\hline & Male & 41 & 55,4 & 25 & 33,8 & 8 & 10,8 & 74 & 100,0 & & \\
\hline \multirow{2}{*}{27} & Female & 44 & 47,8 & 36 & 39,1 & 12 & 13,0 & 92 & 100,0 & \multirow{2}{*}{1,797} & \multirow{2}{*}{$\begin{array}{c}0,40 \\
7\end{array}$} \\
\hline & Male & 43 & 58,1 & 24 & 32,4 & 7 & 9,5 & 74 & 100,0 & & \\
\hline \multirow{2}{*}{29} & Female & 41 & 44,6 & 32 & 34,8 & 19 & 20,7 & 92 & 100,0 & \multirow{2}{*}{0,533} & \multirow{2}{*}{$\begin{array}{c}0,76 \\
6\end{array}$} \\
\hline & Male & 35 & 47,3 & 27 & 36,5 & 12 & 16,2 & 74 & 100,0 & & \\
\hline \multirow{2}{*}{32} & Female & 33 & 35,9 & 31 & 33,7 & 28 & 30,4 & 92 & 100,0 & \multirow{2}{*}{1,987} & \multirow{2}{*}{$\begin{array}{c}0,37 \\
0\end{array}$} \\
\hline & Male & 33 & 44,6 & 25 & 33,8 & 16 & 21,6 & 74 & 100,0 & & \\
\hline \multirow{2}{*}{35} & Female & 41 & 44,6 & 36 & 39,1 & 15 & 16,3 & 92 & 100,0 & \multirow{2}{*}{3,584} & \multirow{2}{*}{$\begin{array}{c}0,16 \\
7\end{array}$} \\
\hline & Male & 38 & 51,4 & 19 & 25,7 & 17 & 23,0 & 74 & 100,0 & & \\
\hline
\end{tabular}

\section{Communication and Relationships}

\begin{tabular}{|c|c|c|c|c|c|c|c|c|c|c|c|}
\hline & Female & 68 & 73,9 & 19 & 20,7 & 5 & 5,4 & 92 & 100,0 & \multirow{2}{*}{4,106} & \multirow{2}{*}{$\begin{array}{c}0,12 \\
8\end{array}$} \\
\hline 4 & Male & 61 & 82,4 & 7 & 9,5 & 6 & 8,1 & 74 & 100,0 & & \\
\hline \multirow{2}{*}{9} & Female & 82 & 89,1 & 8 & 8,7 & 2 & 2,2 & 92 & 100,0 & \multirow{2}{*}{$\cdots$} & \multirow{2}{*}{$\cdots$} \\
\hline & Male & 62 & 83,8 & 11 & 14,9 & 1 & 1,4 & 74 & 100,0 & & \\
\hline \multirow{2}{*}{14} & Female & 70 & 76,1 & 17 & 18,5 & 5 & 5,4 & 92 & 100,0 & \multirow{2}{*}{$\ldots$} & \multirow{2}{*}{$\cdots$} \\
\hline & Male & 60 & 81,1 & 11 & 14,9 & 3 & 4,1 & 74 & 100,0 & & \\
\hline 19 & Female & 68 & 73,9 & 19 & 20,7 & 5 & 5,4 & 92 & 100,0 & $\ldots$ & $\ldots$ \\
\hline
\end{tabular}




\begin{tabular}{|c|c|c|c|c|c|c|c|c|c|c|c|}
\hline & Male & 61 & 82,4 & 9 & 12,2 & 4 & 5,4 & 74 & 100,0 & & \\
\hline \multirow{2}{*}{24} & Female & 76 & 82,6 & 11 & 12,0 & 5 & 5,4 & 92 & 100,0 & \multirow{2}{*}{$\cdots}$. & \multirow{2}{*}{$\cdots$} \\
\hline & Male & 64 & 86,5 & 8 & 10,8 & 2 & 2,7 & 74 & 100,0 & & \\
\hline \multirow[t]{2}{*}{28} & Female & 66 & 71,7 & 20 & 21,7 & 6 & 6,5 & 92 & 100,0 & \multirow[t]{2}{*}{0,878} & \multirow{2}{*}{$\begin{array}{c}0,64 \\
5\end{array}$} \\
\hline & Male & 56 & 75,7 & 12 & 16,2 & 6 & 8,1 & 74 & 100,0 & & \\
\hline \multirow{2}{*}{33} & Female & 60 & 65,2 & 23 & 25,0 & 9 & 9,8 & 92 & 100,0 & \multirow{2}{*}{3,091} & \multirow{2}{*}{$\begin{array}{c}0,21 \\
3\end{array}$} \\
\hline & Male & 52 & 70,3 & 11 & 14,9 & 11 & 14,9 & 74 & 100,0 & & \\
\hline
\end{tabular}

${ }^{*} \mathrm{p}<0.05$ significant $\mathrm{N}=166$

Whether there is a significant correlation between the participants' gender and job satisfaction levels was tested through Chi-square analysis. For the items satisfying the requirements of Chi-square, comparisons were made but for the items 9, 14, 19 and 24 that did not satisfy these requirements, frequencies and percentages were calculated. The findings related to the correlations between the dimensions of the job satisfaction scale and the gender variable and their interpretations are presented below.

\section{Structure of the Job}

As a result of the Chi-square test, it was found that the participants' opinions about the items in the structure of the job section do not vary significantly depending on gender; that is, the female and male participants have similar opinions in this regard. The most frequently expressed opinions by both the female and male participants are that their jobs include diversity and their jobs have negative effects on their personal development. While nearly two thirds of the participants (females $=58.7 \%$; males $=62.2 \%$ ) are of the opinion that their jobs have a prestigious position in the society; $36.5 \%$ of the females and $37 \%$ of the males did not respond. Again while nearly two thirds of the participants stated that they are working in a job complying with their competences (females $=59.8 \%$; males $=56.8 \%$ ), nearly one fourth of both female and male participants did not respond. A little more than half of the participants find their job monotonous while nearly one fourth of the participants think that it is not. In addition, most of the participants do not have positive opinions about the issues such as making their own decisions and using their creativity in their workplace and the ratio of those stating that they would quit, if they had enough money is considerably high.

When a general evaluation is made, it can be said that the jobs in the organization can include diversity, the jobs do not have adequate contributions to the personnel's personal development, the jobs have in general prestigious positions in the society and the personnel in general work in jobs complying with their competences yet their working environment is not very suitable for them to make their own decisions and to use their creativity. Other remarkable findings are that the jobs are considered to be monotonous in general and that they could quit, if their financial situations were better.

\section{Physical Working Conditions}

A significant correlation was found between the perception that there is disturbing noise in the workplace and the gender variable $\left(X^{2}=8.721 ; p<0.05\right.$; correlation coefficient $\left.=0.22\right)$. The correlation coefficient indicates that there is a low correlation and that a great majority of both the female and male participants think that there is noise at the disturbing level in their workplace (females $=70.7 \%$; males $=70.3 \%$ ). However, while only $2.7 \%$ of the male participants stated that there is no noise, the percentage of the female participants thinking in this way is 14.1 and nearly one third of the males $(27 \%)$ did not express any opinions about this issue. The participants' opinions for the other items in this dimension were found to be not varying significantly depending on the gender variable; that is, the female and male personnel have similar opinions. Majority of both female and male participants find lighting and meals in their workplace adequate, think that enough care is taken for hygiene and that the security measures taken in the workplace are satisfying. Nearly one fourth of the female participants 
(26.1\%) have negative opinions about meals and almost one third of the female participants (29.3\%) did not explain their opinions about hygiene rules and one fourth of the male participants $(25 \%)$ did not express their opinions about security measures. Nearly half of both the female and male participants (females $=50.0 \%$ and males $=56.8 \%$ ) think positively about the provision of the needed materials in the workplace in a short time; yet, considerable number of participants either did not express their opinions or think negatively on this issue. On the other hand, nearly half of both the female and male participants (females $=50 \%$, males $=45.9 \%$ ) do not find their wages satisfying. When a general evaluation is made, it can be said that the opinions of the participants about the physical working conditions do not vary significantly in general depending on the gender variable. In general, they have positive opinions about meals, security measures, hygiene and lighting and negative opinions about noise in the workplace. Yet, there are a considerable number of workers who did not express their opinions about these issues. The wages are generally found to be not satisfying by both the female and male workers.

\section{Administrative Policies and Applications}

The participants' opinions about all the items in the administrative policies and applications section were found to be not varying significantly depending on the gender variable; the female and male personnel have similar opinions in this regard. According to the analyses conducted considering the most frequently emphasized opinions, $41.3 \%$ of the female participants and $40.5 \%$ of the male participants think that the promotion system is not transparent and just enough. It is remarkable that $41.9 \%$ of the male participants and $35.9 \%$ of the female participants did not express their opinions on this issue. While nearly one third of both the female and male participants have positive opinions about their being objectively assessed, nearly one third responded negatively and the remaining participants did not respond. While $54.3 \%$ of the female participants and $58.1 \%$ of the male participants stated that they receive constructive feedbacks about their performance in their jobs, nearly one fourth of both the female and male participants stated that they are not sure and one fifth stated that they do not receive constructive feedbacks. The percentage of both the female and male workers stating that their successes are appreciated verbally or in writing is a little more than one third (females $=39.1 \%$; males $=36.5 \%$ ), a significant number of workers stated that they are not sure or not appreciated. Nearly half of both the female and male participants stated that their superiors discriminate between them (females $=51.1 \%$; males $=55.4 \%$ ) and nearly half of both the female and male participants (females $=44.6 \%$, males $=51.4 \%$ ) think that the personnel are valued in their workplace. The percentage of those stating that the desired and undesired behaviors are clearly defined in their work place is $43.5 \%$ among the female workers and $45.9 \%$ among the male workers and it is remarkable that a significant part of both the female and male participants did not express their opinions on this issue. Only half of both the female and male participants stated that their suggestions are taken into consideration in their workplace, they would recommend their jobs to others and the objectives in the workplace are clearly and precisely defined while significant proportion of the participants did not express their opinions or had negative opinions on these issues. Nearly $40 \%$ of both the female and male participants stated that their administration encourages them to establish trust-based, transparent and open relationships in the workplace, their working environment is enjoyable and the administration avoids dismissing good workers; yet, a significant promotion of the participants both female and male did not express their opinions about these issues. When a general evaluation is made, positive opinions about the items in the administrative policies and applications section were generally expressed by almost half of the participants, the ratios of those not responding are quite high both among the female and male workers. In this regard, it can be argued that there are some problems related to objective assessment of the workers, provision of constructive feedbacks and appreciation of the workers verbally or in writing; a significant amount of discrimination is made by administrators among workers and not enough importance is given to workers. Moreover, the percentages of those expressing positive and negative opinions about the issues such as the administration's encouraging the establishment of trust-based, transparent and open relationships, working environment's being enjoyable and avoidance of good workers' dismissal are close to each other, which indicates that there is a significant amount of discontent about these issues.

\section{Communication and Relationships}

In the comparisons made for the items satisfying the requirements of Chi-square in the communication and relationships dimension, it was found that gender is not an influential variable; both the female and male personnel have similar opinions. According to the analyses conducted considering the most frequently emphasized opinions, $73.9 \%$ of the female participants and $82.4 \%$ of the male participants know what they should do in their jobs. High majority of both the female and male participants stated that their relationships with 
their superiors are problematic, they experience difficulties in solving their problems with their colleagues; yet, they are content with their relationships with their colleagues and they can receive help from their colleagues while doing their jobs. High majority of both the female and male participants (females $=71.7 \%$; males $=$ $75.7 \%$ ) stated that they can easily tell their job-related problems to their superiors. Majority of the participants (females $=65.2 \%$; males $=70.3 \%$ ) stated that they experience lack of communication with other workers and one fourth of the female participants (25\%) did not express their opinions on this issue. When a general evaluation for this dimension is made, it can be said that both the female and male participants know what they should do, are content with their relationships with their colleagues, can easily tell their job-related problems to their superiors and can receive help from their colleagues while dealing with a problem in their jobs. On the other hand, both the female and male personnel can experience problems with their superiors, experience difficulties in solving their problems with their colleagues and have lack of communication with other workers.

The participants' job satisfaction characteristics were compared according to the length of service independent variable and the results are presented in Table 4.

Table 4. Job Satisfaction Characteristics according to Length of Service

\begin{tabular}{lllllllllll}
\hline $\begin{array}{l}\text { Item } \\
\text { No }\end{array}$ & $\begin{array}{l}\text { Length } \\
\text { of } \\
\text { Service }\end{array}$ & & 3 & & & 2 & & & & \\
\end{tabular}

\section{Structure of the Job}

\begin{tabular}{|c|c|c|c|c|c|c|c|c|c|c|c|}
\hline & $\begin{array}{l}1-10 \\
\text { years }\end{array}$ & 14 & 37,8 & 15 & 40,5 & 8 & 21,6 & 37 & 100,0 & & \\
\hline \multirow[t]{3}{*}{2} & $\begin{array}{l}11-20 \\
\text { years }\end{array}$ & 32 & 47,8 & 12 & 17,9 & 23 & 34,3 & 67 & 100,0 & 7,534 & 0,110 \\
\hline & $\begin{array}{l}21 \text { years } \\
\text { or more }\end{array}$ & 22 & 35,5 & 18 & 29,0 & 22 & 35,5 & 62 & 100,0 & & \\
\hline & $\begin{array}{l}1-10 \\
\text { years }\end{array}$ & 35 & 94,6 & 1 & 2,7 & 1 & 2,7 & 37 & 100,0 & & \\
\hline \multirow[t]{3}{*}{7} & $\begin{array}{l}11-20 \\
\text { years }\end{array}$ & 52 & 77,6 & 4 & 6,0 & 11 & 16,4 & 67 & 100,0 & $\ldots .$. & $\ldots .$. \\
\hline & $\begin{array}{l}21 \text { years } \\
\text { or more }\end{array}$ & 48 & 77,4 & 4 & 6,5 & 10 & 16,1 & 62 & 100,0 & & \\
\hline & $\begin{array}{l}1-10 \\
\text { years }\end{array}$ & 22 & 59,5 & 9 & 24,3 & 6 & 16,2 & 37 & 100,0 & & \\
\hline \multirow[t]{2}{*}{12} & $\begin{array}{l}11-20 \\
\text { years }\end{array}$ & 42 & 62,7 & 16 & 23,9 & 9 & 13,4 & 67 & 100,0 & 1,374 & 0,849 \\
\hline & $\begin{array}{l}21 \text { years } \\
\text { or more }\end{array}$ & 33 & 53,2 & 17 & 27,4 & 12 & 19,4 & 62 & 100,0 & & \\
\hline 17 & $\begin{array}{l}1-10 \\
\text { years }\end{array}$ & 17 & 45,9 & 7 & 18,9 & 13 & 35,1 & 37 & 100,0 & 2,842 & 0,585 \\
\hline
\end{tabular}




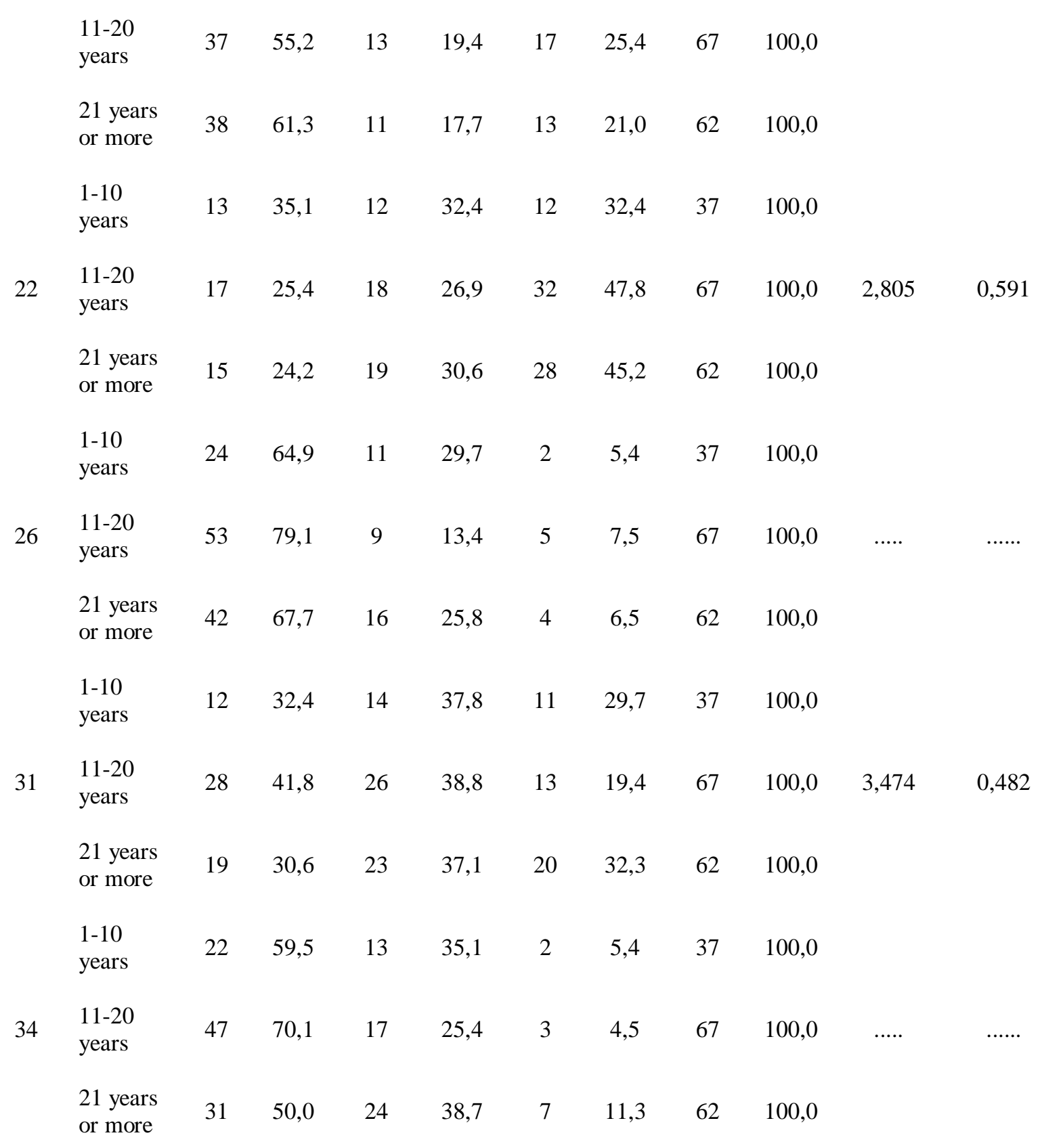

\section{Physical Working Conditions}

\begin{tabular}{|c|c|c|c|c|c|c|c|c|c|}
\hline & $\begin{array}{l}1-10 \\
\text { years }\end{array}$ & 29 & 78,4 & 3 & 8,1 & 5 & 13,5 & 37 & 100,0 \\
\hline 1 & $\begin{array}{l}11-20 \\
\text { years }\end{array}$ & 48 & 71,6 & 3 & 4,5 & 16 & 23,9 & 67 & 100,0 \\
\hline & $\begin{array}{l}21 \text { years } \\
\text { or more }\end{array}$ & 45 & 72,6 & 5 & 8,1 & 12 & 19,4 & 62 & 100,0 \\
\hline
\end{tabular}




\begin{tabular}{|c|c|c|c|c|c|c|c|c|c|c|c|}
\hline & $\begin{array}{l}1-10 \\
\text { years }\end{array}$ & 21 & 56,8 & 9 & 24,3 & 7 & 18,9 & 37 & 100,0 & & \\
\hline \multirow[t]{3}{*}{6} & $\begin{array}{l}11-20 \\
\text { years }\end{array}$ & 44 & 65,7 & 15 & 22,4 & 8 & 11,9 & 67 & 100,0 & 2,993 & 0,559 \\
\hline & $\begin{array}{l}21 \text { years } \\
\text { or more }\end{array}$ & 44 & 71,0 & 9 & 14,5 & 9 & 14,5 & 62 & 100,0 & & \\
\hline & $\begin{array}{l}1-10 \\
\text { years }\end{array}$ & 17 & 45,9 & 8 & 21,6 & 12 & 32,4 & 37 & 100,0 & & \\
\hline \multirow[t]{3}{*}{11} & $\begin{array}{l}11-20 \\
\text { years }\end{array}$ & 29 & 43,3 & 8 & 11,9 & 30 & 44,8 & 67 & 100,0 & 9,288 & 0,054 \\
\hline & $\begin{array}{l}21 \text { years } \\
\text { or more }\end{array}$ & 18 & 29,0 & 6 & 9,7 & 38 & 61,3 & 62 & 100,0 & & \\
\hline & $\begin{array}{l}1-10 \\
\text { years }\end{array}$ & 23 & 62,2 & 13 & 35,1 & 1 & 2,7 & 37 & 100,0 & & \\
\hline \multirow[t]{3}{*}{15} & $\begin{array}{l}11-20 \\
\text { years }\end{array}$ & 51 & 76,1 & 8 & 11,9 & 8 & 11,9 & 67 & 100,0 & 9,245 & 0,055 \\
\hline & $\begin{array}{l}21 \text { years } \\
\text { or more }\end{array}$ & 43 & 69,4 & 13 & 21,0 & 6 & 9,7 & 62 & 100,0 & & \\
\hline & $\begin{array}{l}1-10 \\
\text { years }\end{array}$ & 17 & 45,9 & 9 & 24,3 & 11 & 29,7 & 37 & 100,0 & & \\
\hline \multirow[t]{3}{*}{20} & $\begin{array}{l}11-20 \\
\text { years }\end{array}$ & 42 & 62,7 & 16 & 23,9 & 9 & 13,4 & 67 & 100,0 & 6,200 & 0,185 \\
\hline & $\begin{array}{l}21 \text { years } \\
\text { or more }\end{array}$ & 29 & 46,8 & 20 & 32,3 & 13 & 21,0 & 62 & 100,0 & & \\
\hline & $\begin{array}{l}1-10 \\
\text { years }\end{array}$ & 29 & 78,4 & 5 & 13,5 & 3 & 8,1 & 37 & 100,0 & & \\
\hline \multirow[t]{3}{*}{25} & $\begin{array}{l}11-20 \\
\text { years }\end{array}$ & 49 & 73,1 & 13 & 19,4 & 5 & 7,5 & 67 & 100,0 & $\ldots$. & $\ldots$. \\
\hline & $\begin{array}{l}21 \text { years } \\
\text { or more }\end{array}$ & 38 & 61,3 & 19 & 30,6 & 5 & 8,1 & 62 & 100,0 & & \\
\hline & $\begin{array}{l}1-10 \\
\text { years }\end{array}$ & 29 & 78,4 & 6 & 16,2 & 2 & 5,4 & 37 & 100,0 & & \\
\hline \multirow[t]{2}{*}{30} & $\begin{array}{l}11-20 \\
\text { years }\end{array}$ & 47 & 70,1 & 15 & 22,4 & 5 & 7,5 & 67 & 100,0 & $\ldots .$. & $\ldots$ \\
\hline & $\begin{array}{l}21 \text { years } \\
\text { or more }\end{array}$ & 54 & 87,1 & 4 & 6,5 & 4 & 6,5 & 62 & 100,0 & & \\
\hline
\end{tabular}




\section{Administrative Policies and Administrations}

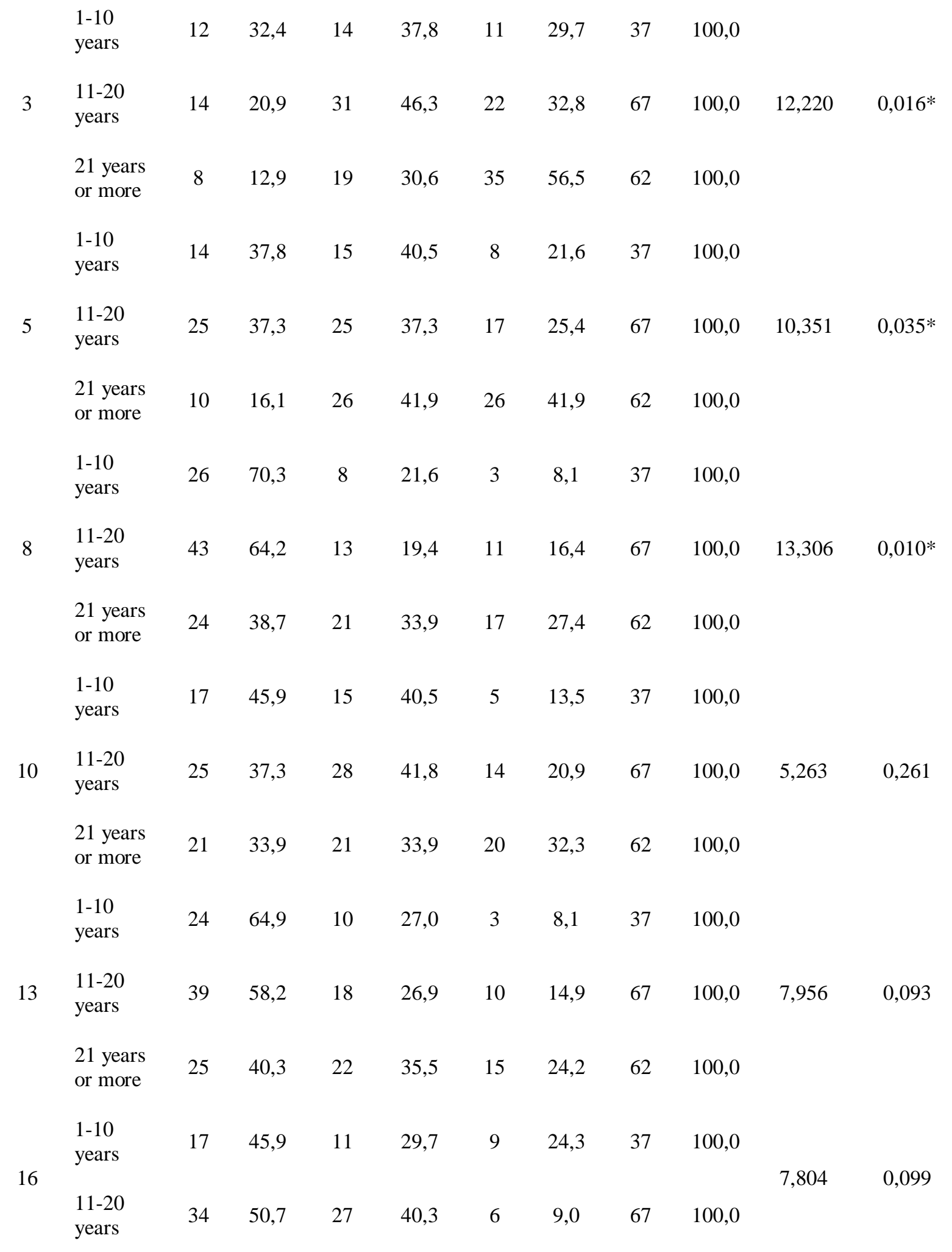




\begin{tabular}{|c|c|c|c|c|c|c|c|c|c|c|c|}
\hline & $\begin{array}{l}21 \text { years } \\
\text { or more }\end{array}$ & 23 & 37,1 & 23 & 37,1 & 16 & 25,8 & 62 & 100,0 & & \\
\hline \multirow{3}{*}{18} & $\begin{array}{l}1-10 \\
\text { years }\end{array}$ & 18 & 48,6 & 16 & 43,2 & 3 & 8,1 & 37 & 100,0 & \multirow{3}{*}{14,578} & \multirow{3}{*}{$0,006^{*}$} \\
\hline & $\begin{array}{l}11-20 \\
\text { years }\end{array}$ & 35 & 52,2 & 27 & 40,3 & 5 & 7,5 & 67 & 100,0 & & \\
\hline & $\begin{array}{l}21 \text { years } \\
\text { or more }\end{array}$ & 20 & 32,3 & 24 & 38,7 & 18 & 29,0 & 62 & 100,0 & & \\
\hline \multirow{3}{*}{21} & $\begin{array}{l}1-10 \\
\text { years }\end{array}$ & 17 & 45,9 & 16 & 43,2 & 4 & 10,8 & 37 & 100,0 & \multirow{3}{*}{5,751} & \multirow{3}{*}{0,219} \\
\hline & $\begin{array}{l}11-20 \\
\text { years }\end{array}$ & 41 & 61,2 & 20 & 29,9 & 6 & 9,0 & 67 & 100,0 & & \\
\hline & $\begin{array}{l}21 \text { years } \\
\text { or more }\end{array}$ & 29 & 46,8 & 21 & 33,9 & 12 & 19,4 & 62 & 100,0 & & \\
\hline \multirow{3}{*}{23} & $\begin{array}{l}1-10 \\
\text { years }\end{array}$ & 26 & 70,3 & 11 & 29,7 & 0 & 0,0 & 37 & 100,0 & \multirow{3}{*}{13,174} & \multirow{3}{*}{$0,010^{*}$} \\
\hline & $\begin{array}{l}11-20 \\
\text { years }\end{array}$ & 34 & 50,7 & 26 & 38,8 & 7 & 10,4 & 67 & 100,0 & & \\
\hline & $\begin{array}{l}21 \text { years } \\
\text { or more }\end{array}$ & 24 & 38,7 & 26 & 41,9 & 12 & 19,4 & 62 & 100,0 & & \\
\hline \multirow{3}{*}{27} & $\begin{array}{l}1-10 \\
\text { years }\end{array}$ & 18 & 48,6 & 15 & 40,5 & 4 & 10,8 & 37 & 100,0 & \multirow{3}{*}{9,039} & \multirow{3}{*}{0,060} \\
\hline & $\begin{array}{l}11-20 \\
\text { years }\end{array}$ & 42 & 62,7 & 22 & 32,8 & 3 & 4,5 & 67 & 100,0 & & \\
\hline & $\begin{array}{l}21 \text { years } \\
\text { or more }\end{array}$ & 27 & 43,5 & 23 & 37,1 & 12 & 19,4 & 62 & 100,0 & & \\
\hline \multirow{3}{*}{29} & $\begin{array}{l}1-10 \\
\text { years }\end{array}$ & 20 & 54,1 & 16 & 43,2 & 1 & 2,7 & 37 & 100,0 & \multirow{3}{*}{16,589} & \multirow{3}{*}{$0,002 *$} \\
\hline & $\begin{array}{l}11-20 \\
\text { years }\end{array}$ & 36 & 53,7 & 21 & 31,3 & 10 & 14,9 & 67 & 100,0 & & \\
\hline & $\begin{array}{l}21 \text { years } \\
\text { or more }\end{array}$ & 20 & 32,3 & 22 & 35,5 & 20 & 32,3 & 62 & 100,0 & & \\
\hline \multirow[b]{2}{*}{32} & $\begin{array}{l}1-10 \\
\text { years }\end{array}$ & 15 & 40,5 & 15 & 40,5 & 7 & 18,9 & 37 & 100,0 & \multirow[b]{2}{*}{6,326} & \multirow[b]{2}{*}{0,176} \\
\hline & $\begin{array}{l}11-20 \\
\text { years }\end{array}$ & 28 & 41,8 & 25 & 37,3 & 14 & 20,9 & 67 & 100,0 & & \\
\hline
\end{tabular}




\begin{tabular}{|c|c|c|c|c|c|c|c|c|c|c|}
\hline $\begin{array}{l}21 \text { years } \\
\text { or more }\end{array}$ & 23 & 37,1 & 16 & 25,8 & 23 & 37,1 & 62 & 100,0 & & \\
\hline $\begin{array}{l}1-10 \\
\text { years }\end{array}$ & 19 & 51,4 & 11 & 29,7 & 7 & 18,9 & 37 & 100,0 & & \\
\hline $\begin{array}{l}11-20 \\
\text { years }\end{array}$ & 37 & 55,2 & 22 & 32,8 & 8 & 11,9 & 67 & 100,0 & 6,605 & 0,158 \\
\hline $\begin{array}{l}21 \text { years } \\
\text { or more }\end{array}$ & 23 & 37,1 & 22 & 35,5 & 17 & 27,4 & 62 & 100,0 & & \\
\hline
\end{tabular}

\section{Communication and Relationships}

\begin{tabular}{|c|c|c|c|c|c|c|c|c|c|}
\hline & $\begin{array}{l}1-10 \\
\text { years }\end{array}$ & 29 & 78,4 & 4 & 10,8 & 4 & 10,8 & 37 & 100,0 \\
\hline \multirow[t]{3}{*}{4} & $\begin{array}{l}11-20 \\
\text { years }\end{array}$ & 51 & 76,1 & 12 & 17,9 & 4 & 6,0 & 67 & 100,0 \\
\hline & $\begin{array}{l}21 \text { years } \\
\text { or more }\end{array}$ & 49 & 79,0 & 10 & 16,1 & 3 & 4,8 & 62 & 100,0 \\
\hline & $\begin{array}{l}1-10 \\
\text { years }\end{array}$ & 30 & 81,1 & 6 & 16,2 & 1 & 2,7 & 37 & 100,0 \\
\hline \multirow[t]{3}{*}{9} & $\begin{array}{l}11-20 \\
\text { years }\end{array}$ & 62 & 92,5 & 4 & 6,0 & 1 & 1,5 & 67 & 100,0 \\
\hline & $\begin{array}{l}21 \text { years } \\
\text { or more }\end{array}$ & 52 & 83,9 & 9 & 14,5 & 1 & 1,6 & 62 & 100,0 \\
\hline & $\begin{array}{l}1-10 \\
\text { years }\end{array}$ & 29 & 78,4 & 6 & 16,2 & 2 & 5,4 & 37 & 100,0 \\
\hline \multirow[t]{3}{*}{14} & $\begin{array}{l}11-20 \\
\text { years }\end{array}$ & 56 & 83,6 & 8 & 11,9 & 3 & 4,5 & 67 & 100,0 \\
\hline & $\begin{array}{l}21 \text { years } \\
\text { or more }\end{array}$ & 45 & 72,6 & 14 & 22,6 & 3 & 4,8 & 62 & 100,0 \\
\hline & $\begin{array}{l}1-10 \\
\text { years }\end{array}$ & 27 & 73,0 & 9 & 24,3 & 1 & 2,7 & 37 & 100,0 \\
\hline \multirow[t]{2}{*}{19} & $\begin{array}{l}11-20 \\
\text { years }\end{array}$ & 51 & 76,1 & 12 & 17,9 & 4 & 6,0 & 67 & 100,0 \\
\hline & $\begin{array}{l}21 \text { years } \\
\text { or more }\end{array}$ & 51 & 82,3 & 7 & 11,3 & 4 & 6,5 & 62 & 100,0 \\
\hline 24 & $\begin{array}{l}1-10 \\
\text { years }\end{array}$ & 30 & 81,1 & 6 & 16,2 & 1 & 2,7 & 37 & 100,0 \\
\hline
\end{tabular}




\begin{tabular}{|c|c|c|c|c|c|c|c|c|c|c|c|}
\hline & $\begin{array}{l}11-20 \\
\text { years }\end{array}$ & 59 & 88,1 & 6 & 9,0 & 2 & 3,0 & 67 & 100,0 & & \\
\hline & $\begin{array}{l}21 \text { years } \\
\text { or more }\end{array}$ & 51 & 82,3 & 7 & 11,3 & 4 & 6,5 & 2 & 100,0 & & \\
\hline \multirow{3}{*}{28} & $\begin{array}{l}1-10 \\
\text { years }\end{array}$ & 30 & 81,1 & 6 & 16,2 & 1 & 2,7 & 37 & 100,0 & \multirow{3}{*}{$\ldots$} & \multirow{3}{*}{$\ldots \ldots$} \\
\hline & $\begin{array}{l}11-20 \\
\text { years }\end{array}$ & 52 & 77,6 & 11 & 16,4 & 4 & 6,0 & 67 & 100,0 & & \\
\hline & $\begin{array}{l}21 \text { years } \\
\text { or more }\end{array}$ & 40 & 64,5 & 15 & 24,2 & 7 & 11,3 & 62 & 100,0 & & \\
\hline \multirow{3}{*}{33} & $\begin{array}{l}1-10 \\
\text { years }\end{array}$ & 22 & 59,5 & 12 & 32,4 & 3 & 8,1 & 37 & 100,0 & \multirow{3}{*}{4,775} & \multirow{3}{*}{0,311} \\
\hline & $\begin{array}{l}11-20 \\
\text { years }\end{array}$ & 48 & 71,6 & 10 & 14,9 & 9 & 13,4 & 67 & 100,0 & & \\
\hline & $\begin{array}{l}21 \text { years } \\
\text { or more }\end{array}$ & 42 & 67,7 & 12 & 19,4 & 8 & 12,9 & 62 & 100,0 & & \\
\hline
\end{tabular}

$* \mathrm{p}<0.05$ significant $\mathrm{N}=166$

Whether there is a significant correlation between the participants' job satisfaction levels and length of service was tested by using Chi-square test. Comparisons were made for the items satisfying the requirements of Chi-square test; yet, for the items $1,4,7,9,14,19,24,25,26,28,30$ and 34 not satisfying these conditions, frequencies and percentages were calculated. The findings related to the correlations between the dimensions of the job satisfaction scale and the length of service variable and their interpretations are presented below.

\section{Structure of the Job}

As the items 7, 26 and 34 did not satisfy the requirements for conducting Chi-square test within the context of this dimension to analyze whether the participants' opinions vary significantly depending on the length of service independent variable, frequencies and percentages were calculated for these items. For the other items, Chi-square test was conducted and the results revealed that the length of service independent variable is not an influential variable; that is, the personnel with differing lengths of service have similar opinions. According to the analyses conducted considering the most frequently expressed opinions, $94.6 \%$ of the participants working for 1-10 years think that they cannot use their creativity in their jobs while $77.6 \%$ of the participants working for 11-20 years and $77.4 \%$ of the participants working for 21 years or more think so. Another item on which the personal with differing lengths of service have similar opinions is making their own decisions. In this connection, nearly half of the participants working for 11 years or more stated that they cannot make their own decisions while one third of the participants working for 1-10 years expressed the same opinion. On the other hand, nearly one third of the participants working for 1-10 years stated that they can make and implement their own decisions while only one fourth of the participants working for 11 years or more stated that they can make and implement their own decisions. While most of the participants have positive opinions about the prestige of their jobs in the society, one third of the participants working for 1-10 years and one fourth of the participants working for 21 years or more are not sure about this. High majority of all the participants from different groups of length of service find their working environments monotonous and nearly one fourth of each group are not sure about this and nearly one fifth of them stated that it is not monotonous. Majority of the participants from the three groups of length of service $(1-10$ years $=59.5 \% ; 11-20$ years $=70.1 \% ; 21$ years or more $)$ think that their jobs have negative contributions to their professional development and remarkable portion of them stated that they are not sure about this. In terms of working in a job complying with their competences, the participants 
working for 21 years or more agree to a greater extent $(61.3 \%)$ and nearly half of the other two groups have similar opinions. On the other hand, nearly one third of the participants working for 1-10 years and nearly one fourth of the members of the other two groups of length of service think that they are working in a job complying with their competences. The ratio of those stating that the job they are doing includes diversity is nearly half of the participants working for 11-20 years or more and is a little more than one third of the other two groups. It is remarkable that nearly one third of the personnel working for 21 years or more and $41.8 \%$ of the personnel working for 11-20 years stated that they would quit their jobs if they had enough money. The ratio of those stating that even if they had enough money, they would not quit their jobs is at least one fourth of the participants. In this connection when a general evaluation is made, it can be said that most of the participants in the three groups of length of service think that they cannot use their creativity in their jobs, they do monotonous jobs and with increasing length of service, the number of those thinking that they are working in a job complying with their competences increases. It can also be argued that those with less experience are more pessimistic about this issue. There seem to be problems in terms of making and implementing their own decisions. With increasing experience, the ratio of those who can implement their own decisions decreases. In general the diversity involved in their jobs is limited. Most of the participants also think that they would quit if they had enough money.

\section{Physical Working Conditions}

As the items 1, 25 and 30 did not satisfy the requirements for conducting Chi-square test within the context of this dimension to analyze whether the participants' opinions about physical working conditions vary significantly depending on the length of service independent variable, frequencies and percentages were calculated for these items. For the other items, Chi-square test was conducted and the results revealed that the length of service independent variable is not an influential variable; that is, the personnel with differing lengths of service have similar opinions. According to the analyses conducted considering the most frequently expressed opinions, the item about which the members of the three groups of length of service have similar opinions to a great extent is the lightning in the workplace $(1-10$ years $=78.4 \% ; 11-20$ years $=70.1 \%$; 21 years or more $=$ $87.1 \%)$. Another item on which the members of the three groups of length of service have similar opinions concerns hygiene rules $(1-10$ years $=78.4 \% ; 11-20$ years $=73.1 \% ; 21$ years or more $=61.3 \%)$. Nearly three fifths of the workers working for 11-20 years, nearly half of the workers working for 1-10 years and nearly half of the workers working for 21 years or more stated that the materials needed in the workplace are immediately provided. Nearly one fourth of the members of the three groups of length of service stated that they are not sure about this issue. The percentages of those stating that there is disturbing noise in their workplace are generally high $(1-10$ years $=62.2 \% ; 11-20$ years $=76.1 \% ; 21$ years or more $=69.4 \%)$ and also the ratio of those stating they are not sure about this is also high. In relation to the wage they receive in their jobs, $61.3 \%$ of the workers working for 21 years or more find it inadequate while nearly half of the other two groups find it satisfying. In terms of finding the security measures taken in the workplace adequate, all the groups of length of service stated that they are adequate to a great extent $(1-10$ years $=56.8 \% ; 11-20$ years $=65.7 \% ; 21$ years or more $=71.0 \%)$. It is remarkable that one fifth of the personnel working for 1-10 years and working for 11-20 years are not sure about it. Most of the members of all the groups of length of service find meals offered in the workplace satisfying $(1-10$ years $=78.4 \% ; 11-20$ years $=71.6 \% ; 21$ years or more $=72.6 \%)$. One fifth of the workers working for 11-20 years do not find meals satisfying.

\section{Administrative Policies and Applications}

Chi-square analyses conducted in relation to the relationship between the dimension of administrative policies and applications and length of service revealed that the participants' opinions about the items $3,5,8,18$, 23 and 29 vary significantly depending on length of service. While nearly more than half of the participants working for 21 years or more stated that the promotion system is not transparent enough while almost half of the participants working for 11-20 years (46.3\%) stated that they are not sure. When the ratios of those stating positive opinions about this issue are examined, it is seen that one third of those working for 1-10 years are of the opinion that the promotion system is transparent and just. In terms of objective assessment in the workplace, the personnel with higher length of service have more negative opinions and the less experienced workers agree more with the idea that feedbacks in the workplace are constructive $(1-10$ years $=70.3 \% ; 11-20$ years $=64.2 \%)$ and nearly half of the less experienced workers agree with the idea that the administration encourages the establishment of trust-based, open and transparent relationships. It is remarkable that nearly $40 \%$ of the members of the three groups of length of service are not sure about this issue. The most positive opinions about the 
consideration of the suggestions related to the job were stated by the participants working for 1-10 years with $70.3 \%$ and nearly half of the participants working for 11-20 years agree with this idea. Most of the participants working for 21 years or more are not sure about this issue. The idea that the dismissal of good workers should be avoided is supported by nearly half of the participants working for 1-20 years. The ratios of the ones in the three groups who are not sure about this issue are remarkable.

As a result of the Chi-square analyses conducted for the other items in this dimension, it was found that length of service is not a variable significantly affecting opinions about these items; that is, the participants from different length of service groups have similar opinions. While nearly half of the workers working for 1-10 years have positive opinions about the appreciation of the successes of workers verbally or in writing, nearly one third of the members of the other groups agree with this statement. It is remarkable that a considerable number of participants stated that they are not sure about this issue. The agreement with the idea that superiors discriminate between workers is the highest among the participants working for 1-10 years $(64.9 \%)$, more than half of the participants working for 11-20 years (58.2) also agree with this statement. With the statement that desired and undesired behaviors in the work place have been clearly defined, 50.7\% of the participants working for 11-20 years agree, while this ratio is $45.9 \%$ for those working for 1-10 years. On the other hand, a significant portion of the three groups stated that they are not sure about this issue. While two thirds of the participants working for 1120 years stated that they would recommend their workplace to others to work and objectives are clear in their workplace, nearly half of the other groups do not have positive opinions about these issues. A significant proportion of the three groups ranging from $30 \%$ to $43 \%$ state that they are not sure about this issue. Two fifths of the participants working for 11-20 years stated that they find their workplace enjoyable and another two fifths of them stated that they are not sure and again two fifths of the participants working for 21 years or more do not find their workplace enjoyable. While a little more than half of the participants working for 1-20 years have positive attitudes about being valued in their workplace, $37.1 \%$ of the participants working for 21 years or more agree with this idea.

The findings of the current study showed that with increasing length of time, the ratio of the participants thinking that the promotion system is just and transparent and the personnel are assessed objectively decreases. The participants with shorter length of service have more positive opinions about receiving constructive feedbacks. Nearly half of the participants working for 1-20 years have more positive attitudes about the establishment of trust-based and transparent relationships. In terms of their suggestions' being taken into consideration, the participants working for 1-10 years have more positive opinions. In terms of the verbal and written appreciation of their achievements, the ratio of the participants having positive opinions is nearly equal to the ratio of the participants who are not sure. The participants with less experience think that administrators discriminate between the workers to a greate extent. Though the ratio of those reporting positive opinions about recommending their jobs to others and clarity of the objectives is a little more than the others, the ratio of those who are not sure about these issues is also considerably high. The ratios of those finding their workplace enjoyable and of those who are not sure are close to each other. Nearly half of the participants working for 1-20 years think that the workers are valued in their workplace. Nearly one third of the participants from the three groups of length of service are not sure about this issue.

\section{Communication and Relationships}

As the items 4, 9, 14, 19, 21 and 28 did not satisfy the requirements for conducting Chi-square test within the context of the dimension of communication and relationships to analyze whether the participants' opinions about communication and relationships vary significantly depending on the length of service independent variable, frequencies and percentages were calculated for these items. Chi-square analysis conducted for item 33 revealed that length of service is not an influential variable on the participants' opinions; thus, all the participants from differing lengths of service have similar opinions in this regard. According to the analyses conducted considering the most frequently expressed opinions by the participants, the item about which the members of the three groups of length of service have similar and positive opinions to a great extent is their knowing what they should do in their jobs $(1-10$ years $=78.4 \% ; 11-20$ years $=76.1 \% ; 21$ years or more $=79.0 \%)$. High majority of the participants from the three groups of length of service stated that they experience problems in their relationships with their superiors $(1-10$ years $=81.1 \% ; 11-20$ years $=92.5 \% ; 21$ years or more $=83.9)$. One of the item about which the participants from all the length of service groups expressed similar and positive opinions to a great extent is their being content with their relationships with their colleagues $(1-10$ years $=78.4 \%$; $11-20$ years $=$ 
$83.6 \% ; 21$ years or more $=72.6 \%$ ). On the other hand, it was also elicited that they experience problems with their colleagues and experience difficulty in solving these problems and $24.3 \%$ of the participants working for 1 10 years think so, which is a remarkable finding. Four fifths of the workers from all the length of service groups stated that they can get help from their friends when they encounter any problem. In relation to the item "I can easily tell my problems related to the job to my superiors", $81.1 \%$ of the personnel working for $1-10$ years, $77.6 \%$ of the personnel working for $11-20$ years and $64.5 \%$ of the personnel working for 21 years or more expressed positive opinions. Nearly one fourth of the workers working for 21 years or more $(24.2 \%)$ stated that they are not sure about this item. The ratio of those stating that they experience lack of communication with other workers while doing their jobs is $59.5 \%$ for the workers working for $1-10$ years, $71.6 \%$ for the workers working for $11-20$ years and $67.7 \%$ for the workers working for 21 years or more. A considerable part of those working for 1-10 years (32.4\%) stated that they are not sure.

Thus, it was concluded that length of service is not an influential variables in the workers' communication and relationships; all the participants regardless of their length of service have similar opinions. When a general evaluation is made in relation to this dimension, it can be said that regardless of their length of service, the workers know what they should do in their jobs and are content with their relationships with their colleagues. However, when they experience a problem with their colleagues, they have difficulty in finding solutions and they also experience problems with their superiors. It was also found that the participants' opinions about the items "I can get help from other workers related to my job", "I can easily tell my problems to my superiors", "I can experience communication problems while doing my job" do not vary significantly depending on their length of service.

\section{Discussion and Results}

As a result of the current study, following interpretations can be made about the personnel working in a general directorate of the Ministry of National Education:

The participants mostly do not have positive opinions about items related to use of creativity, working in jobs complying with their competences and the prestigious position of their jobs in the society within the dimension of structure of the job. One third of the personnel do not have positive opinions about the items related to prestigious position of their jobs and working in jobs complying with their competences. In addition, the workers mostly cannot make and implement their own decisions and find their jobs monotonous. In the study conducted by Karaköse and Kocabaş (2006) to explore job satisfaction in teachers working in private and state schools, it was found that the teachers think that their jobs are not much prestigious, which supports the relevant finding of the current study. Erdoğan (2017) reported that most of the people working in state organizations have low job satisfaction, which concurs with the finding of the current study.

In relation to physical working conditions, while in general the participants have positive opinions about meals, security measures, hygiene, lighting, they have negative opinions about the noise in the workplace. Moreover, the wages are generally found to be inadequate.

In relation to administrative policies and applications, most of the participants think that they receive constructive feedbacks related to their jobs, would recommend their friends to work in their workplace and their job-related suggestions are taken into consideration. But, the ratio of the participations not responding to many items is remarkable. In addition to this, it can be argued that they are generally of the opinion that there is not a transparent and just promotion system, workers are not objectively assessed, superiors discriminate between workers and they do not find their workplace enjoyable. Karaköse and Kocabaş (2006) conducted a study to investigate the job satisfaction of teachers working in private and state schools and revealed that there are some differences between these two types of schools in terms of administrators' taking the personnel's opinions into consideration while making their decisions as the administrators in the state schools do not consider their personnel opinions while making their decisions moreover, the administrators working in the state schools attach less importance to the reinforcement of their personnel's positive behaviors.

Within the context of communication and relationships, it can be said that the participants generally know what they should do in their jobs. Moreover, they are content with their relationships with their colleagues, can ask for help from their colleagues when they have problems and can easily tell their job-related problems to their superiors. However, in general the participants also experience problems in their relationships with their 
superiors. Given that the relationships with superiors are of great importance for the job satisfaction of workers (Özsüer, 2016), it is a fact that the problems experienced with superiors will negatively affect their job satisfaction. It was also found in the current study that the personnel experience problems with their colleagues, they can have difficulties in solving these problems and they can have communication problems with other workers. Similar findings were obtained by Karaköse and Kocabaş (2006) in their study investigating the job satisfaction of teachers working in private and state schools and reporting that both the private and state school teachers have good relationships with their colleagues. This is parallel to the findings of the study by Eryllmaz (1987). Eryılmaz (1987) concluded that organizational communication is of vital importance for the motivation of workers.

The gender-based companions revealed that the participants' opinions about the dimensions of structure of the job, administrative policies and applications and communication and relationships do not vary significantly depending on gender. In Sağır's study (2016) conducted on the personnel working in the Life Long Learning General Directorate of the Ministry of National Education, it was also concluded that the gender variable does not have significant effects on their job satisfaction. In studies by Kılıç (2011), Avşaroğlu and Deniz (2005), Tüzemen (2004), Ayan, Kocacık and Karakuş (2009) and Çekiç (2017), it has been found that job satisfaction does not vary significantly by gender, which supports the finding of the current study. Only significant difference based on gender was found between the opinions of the female and male participants about the disturbing level of noise in the workplace. Though in general both groups complain about the noise in the workplace, one third of the male participants did not state their opinions on this issue, which may indicate that they do not care about or are not aware of the noise.

The comparisons made on the basis of length of service revealed no significant difference in relation to the structure of the job dimension. The general opinion in three of the length of service groups is that the personnel cannot use their creativity, they do monotonous jobs and their jobs do not have much positive contribution to their personal development. In this dimension, the less experienced personnel were found to be more pessimistic. A significant part of the participants from the three length of service groups stated that they would give up their jobs, if they had enough money. In a similar manner, Sağır (2016) found the wage as an important variable affecting job satisfaction. Thus, it can be argued that the personnel are not content with their wages in general.

Within the content of the dimension of physical working conditions, it was found that the length of service variable is not an influential variable; the personnel from different length of service groups have similar opinions. Thus, high majority of the personnel from the three groups of length of service have positive opinions about lighting, hygiene in their workplace. The personnel from different length of service groups generally think that there is a disturbing level of noise in their workplace yet find meals and security measures satisfying. The personnel with longer service tend to find their wages less satisfying.

When the effect of length of service on the dimension of administrative policies and applications are examined, it can be said that with increasing length of service, the number of participants finding the promotion system transparent and just and thinking that the personnel are objectively assessed decreases thus it can be argued that with increasing length of service, job satisfaction decreases. Similarly, Acar (2016) also found that with increasing length of service, job satisfaction decreases. Nearly half of the participants working for 1-20 years have positive opinions about the establishment of trust-based and transparent relationships. The participants working for 1-10 years have relatively more positive opinions about their job-related suggestions' being taken into consideration, yet, a considerable part of them think that there is a discrimination between workers in the workplace. The ratios of the participants finding their workplace enjoyable and of the participants who are not sure about it are close to each other. Nearly half of the participants working for 1-20 years think that they are valued in their workplace. Nearly one third of the three groups of length of service are not sure about this.

Regardless of length of service, they mostly know what they should do in their jobs and are content with their relationships with their colleagues. Yet, when they experience problems with their colleagues, they generally have difficulties in solving them and they can also experience problems with their superiors. Moreover, the participants' opinions about receiving help from their colleagues when they have job-related problems, telling their problems to their superiors and experiencing problems with their superiors while doing their jobs were found to be not varying significantly depending on the length of service variable. 


\section{Suggestions}

In light of the findings of the current study, following suggestions can be made:

1. The personnel find their jobs monotonous. In this regard, it can be suggested that in the performance of routine tasks not requiring specialization, the personnel can be rotated so that they can engage in different tasks and may decrease the sense of monotony.

2. Social activities including all the personnel and even their families can be organized to strengthen the relationships between them (cinema, concert, poem performance etc.) so that the sense of monotony can be decreased.

3. Precautions that aim to reduce physical exhaustion such as ergonomic chairs, desks, mouse pads supporting the wrist, and orthopedic back supports placed in chairs may help increase the workers' job commitment and reduce tiredness-based sense of monotony.

4. Workers can be allowed to spend some time in the library and to visit other organizations in a planned manner.

5. The personnel stated that they cannot make and implement their own decisions in general. If they are allowed to take part in decisions made in their organizations, they feel more valued and committed.

6. In general, the personnel do not have positive opinions about the fit between their jobs and competences and the prestigious position of their jobs in the society. Therefore, if they are allowed to work in units and jobs which they find more suitable for their competences and abilities and if they are given seminars, courses and trainings to develop themselves so that they can acquire new skills and competences and work in jobs they want, then their job satisfaction may increase.

7. The personnel in general stated that there is a disturbing level of noise in their workplace. For those who have to share the same room with others although they are doing different jobs or for those they are obliged to use the same room with others due to shortage of rooms, better working conditions should be created. In this regard, better planning of room allocations can help alleviate the problem.

8. The personnel mostly find their wages inadequate. Thus, if their wages can be increased or special efforts are awarded with premiums, then their job satisfaction can be improved and they can be more willing to accomplish and to increase their performance.

9. The personnel stated that in general their superiors discriminate between them. In this regard, it would be useful to make the promotion system more transparent and objective.

10. Majority of the participants stated that they do not find their working environment enjoyable. Encouraging workers to work in cooperation with specialists and other personnel doing the same or similar jobs in other organizations and activities such as establishing a choir, a theater group of the organization will make the workplace more enjoyable. For enhancing job satisfaction of their personnel, organizations need to focus on elements conducive to motivation such as making the job more interesting, exciting and offering incentives.

11. Some of the participants stated that they experience problems in communicating with their superiors. Organizing training programs for all the administrative staff and other personnel to make them informed about issues such as effective communication, empathy, social values will make positive contributions to job satisfaction.

12. A considerable number of participants stated that they experience lack of communication with their colleagues in their workplace. Job descriptions, authorities and responsibilities should be defined clearly.

13. Nearly one third of the participants did not respond to the questions. This might be not because they do not have any opinions about the issues but rather they refrain from answering. A secure environment should be established for workers to express themselves freely. 
14. During the administration of the scale by the researcher, a general unhappiness, hesitation and weariness were observed in the personnel. In 1880, a women visiting French neurologist Jules Cotard said that she could not feel her brain, nerve cells and stomach and she even said that she was dead. Due to these thoughts, the woman was convinced that she would not need to eat. A similar case was encountered by French naturalist and philosophy writer Charles Bonnet (Ak, 2016). There was a woman who was paralyzed as a result of the strike on the neck and Bonnet understood that when this woman regained her ability to speak, she believed that she had died. In the literature, these cases are called as the Cotard syndrome and the walking dead syndrome, which might be a partial reason why some of the participants did not respond to the questions and why they found their jobs monotonous. 


\section{Millî Eğitim Bakanlı̆̆ı Personelinin İș Doyumu (Bir Genel Müdürlük Örneği)}

\section{Giriş}

Belli bir eğitim ile kazanılan sistemli bilgi ve becerilere dayalı, insanlara yararlı mal üretmek, hizmet vermek ve karşıllğında para kazanmak için yapılan, kuralları belirlenmiş iş şeklinde tanımlanan meslek, insan yaşamında en önemli seçim ve en çok zamanını harcadığı uğraşıdır. Hayatın bu denli büyük bir bölümünü kaplayan uğraşı icra ederken gerekli olan motivasyon ve mutluluk ise tartışılmaz bir gereksinimdir. İş yaşamında bireyi motive eden gereksinimler ne kadar iyi anlaşılabilirse, bu gereksinimlerden faydalanarak her anlamda sağlıklı çalışma koşulları da oluşturulabilir. Sağlıklı çalışma koşulları da hem çalışan hem de kurum için önem arz etmektedir. Personelin moralinin yüksek olması, yöneticilerle uyumlu çalışabilme, iş arkadaşlarıyla uyum, çalışanların beklentilerinin karşılanması, işyerinin fiziksel koşullarının uygunluğu, objektif yönetim anlayışları, başarıların takdiri gibi daha da çoğaltılabilecek pek çok durum iş yerindeki motivasyonu etkilemektedir. Motivasyon, bireylerdeki içsel enerjinin belirli hedeflere yönlendirilmesi için hareketlendirilmesi, aktive edilmesidir (Düren, 2000, s. 4). Akat'a (1984, s.175) göre motivasyon ise; ferdi veya fertleri belirli bir yöne doğru devamlı şekilde harekete geçirmek için gösterilen çabaların toplamıdır.

Bireyin iş yerinde olumlu çalışma koşullarına sahip oluşu, motivasyonu ve bu durumlara olan tepkisi iş doyumu ile ifade edilmektedir. İş doyumu kavramı çalışanların işlerine karşı gösterdikleri içsel bir tepkiyle ilgilidir. İş doyumu çeşitli şekillerde ifade edilmektedir. İş doyumu; "Bir bireyin işini ya da iş ile ilgili yaşantısını, memnuniyet verici veya olumlu bir duygu ile sonuçlanan bir durum olarak takdir etmesidir" (Çetinkanat, 2000). İş doyumu iş durumuna duygusal bir tepkidir. Bu nedenle görülmez, ancak anlaşılır. İş̧ doyumu genellikle çıktıların beklentileri ne kadar karşıladığı veya aştığına göre belirlenir.

İş doyumuna yönelik bir başka tanıma göre iş doyumu bireyin işine ve işyerine dair tutumunu, genel duygu ve düşüncelerini içerir (Miner, 1992, s. 116). İnsanların işlerinden memnuniyetleri doyum memnun olmama durumları ise doyumsuzluk olarak değerlendirilir (Spector, 1997, s. 6). Gerek iş doyumu gerekse mesleki tükenmişlik konuları üzerine işletme, örgüt psikolojisi, yönetim alanlarında yoğun bir şekilde çalışılmaktadır. Stres pekçok sağllk sorununa neden olduğu gibi çalışanlarda iş doyumsuzluğu ve motivasyon eksikliğine de neden olmaktadır. Bireyler stresle başetmeye çalışırken üzüntü, kızgınlık, korku gibi farklı farklı duygularla kimi zamanda baş edememeye yönelik tepkiler verirler (Smith, Jaffe-Gill \& Seggl, 2009).

Literatürde iş doyumuyla ilgili teoriler motivasyon kuramları olarak da anılır. Motivasyonda bireyin belirli yöne doğru yönlenme veya yönlendirilme gücü söz konusudur. Bu güç içsel (bilişsel) veya dışsal (çevresel) olabilir (Bilgin, 2003, s. 248). Motivasyon konusundaki içerik kuramlarından biri Herzberg teorisidir. Bu teoriye göre işyerindeki etkenler doyum ve doyumsuzluğu belirler. Bu etkenler içsel veya dışsal olabilir. İçsel etkenler bireyin karakter özellikleri, işin yapısı, bireyin başarı durumu olarak düşünülebilir (Judge, Parker, Colbert, Heler, ve Ilıes 2001). Dışsal etkenler ise doyumsuzlukla ilgili iş koşullarının kötü olması, hijyenden yoksun çalışma koşulları, ücretlerin düşük olması, güvenlik ihtiyacının karşılanmaması olarak düşünülebilir. Bu söz konusu dişsal etkenler olumlu olursa bu motivasyona etki etmemekte ama tatminsizliği önlemektedir (Northcraft ve Neale, 1990, s. 139). McClelland -psikolojik modernleşme teorisyenlerinden- bireyin, ilişki kurma ihtiyacı (affiliation needs), güç kazanma ihtiyacı (power needs) ve başarma ihtiyacı (achievement needs) olmak üzere üç önemli ihtiyacı olduğunu belirtmektedir. Bu üç ihtiyaçtan başarma ihtiyacı bireyi ve toplumu en çok etkileyendir (Eren, 2008, s. 522).

Bireyin başarma ihtiyacının karşılanmaması doyumsuzluğa doğru br gidiş anlamına gelir. Keser'e göre (2005) iş yaşamındaki doyumsuzluk işe gitmeme, düşük performansla çalışma, hayata dönük genel tatminsizlikle sonuçlanabilir. İşteki doyumsuzluk tükenmişliğe tükenmişlik ise kişisel başarının azalması, duyarsızlaşma ve duygusal tükenme şeklinde bir yol izleyerek istenmeyen sonuçlara doğru yol alır (Maslach ve Jackson, 1981). İş doyumu çalışanların iş yaşamlarına profesyonel olarak devamlarının sağlanmasında önemli bir kavramdır (Pillay, Goddard ve Wilss, 2005). Çalışanların kendi iş performansını yeterli bulmadıklarında öz yeterliliklerinden şüpheye düşecekleri belirtilmiştir (Brouwers, Evers ve Tomic, 2001).

Süreç teorileri adı altında toplanan motivasyon teorileri, kişilerin nasıl motive olduklarıyla ilgilenir. Süreç teorileri Klasik Şartlanma, Beklenti Kuramı ve Eşitlik ve Amaç Teorisidir (Erdem, 1998). Bu süreç kuramlarından Eşitlik ve Amaç Teorisi, General Electric kurumunda yaptığı güdülenme çalışmaları sonrası O. 
Stacy Adams tarafından ortaya konulmuştur. Teoriye göre bireyler genel anlamda denklik, adalet ve eşitlik kavramlarına önem verirler ve bu kavramları içeren muamele görmek isterler. Çalışan sarf ettiklerini girdi bu emek sonucu elde ettiklerini de çıktı olarak nitelendirir ve bir hesap yapar. Çalışan girdinin fazla çıktının az olduğuan kanaat getirirse emeğinin karşılığını alamadığını, çıktı beklentisinden fazla ise hak ettiğinden fazla olduğunu düşünür. Bu durumlarda iş doyumunda düşme yaşanacağı öngörülür. Ayrıca çalışan problemlerin, uyuşmazlıkların adaletli bir şekilde çözüldüğüne kanaat getirmezse işi doyumu ve işine bağlılığı azalır (Perry,1993; Eren, 2008; Keskin, Akgün ve Günsel, 2008; Bilgin, 2003).

Çalışanın işteki davranışını belirleyen işi ile ilgili tutumlarıdır bu tutumlar ise; çalışanların yetkilendirilmesi, hatalara karşı hoşgörü, kararların netliği, çalışanın karar sürecine katılması, olumlu çalışma koşulları gibi ve daha pekçok etkenin tamamı sonucu oluşur (Pascoe, Ali ve Warne, 2002; akt: Ertürk ve Keçelioğlu, 2012). Rekabet ortamı, küreselleşme, teknolojik gelişim hızı kurum ve çalışanlar üzerinde baskı oluşturmaktadır. Bu baskıyı azaltıcı etkenlerden biri iş doyumunu arttırmaktır. İş doyumuna ulaşamayan bireyler kişisel geçmişlerine, karakter özelliklerine, iş yerinin yönetim sistemine göre değişik tepkiler verebilirler bu tepkilerin başlıcaları; işe devamsızlık yapma, iş yerinde kendi özel işlerini halletme, molaları uzatma, kuralları çiğneme, saldırgan tavırlar sergilemektir (Sun, 2002).

Çalışanların iş doyumuna ulaşamaması tükenmişliğe yol açabilir. Maslach ve Jackson (1986) tarafından ortaya konan tükenmişlik, işi insanlarla ilgili olan çalışanlarda daha yoğun gözlemlenmiştir. Tükenmişlik, yoğun stres, işinden soğuma, sürekli umutsuzluk, işinde farklılık yaratamayacağı düşüncesi, doyumsuzluk, yaşam enerjisinin tükenmesi, bırakmışlık ve teslimiyet gibi durumlardan doğar (Barutçu ve Serinkan, 2008; Kaçmaz, 2005). Maslach'a göre tükenmişlik duygusal tükenme (emotional exhaustion), duyarsızlaşma (depersonalization) ve kişisel başarısızlık (personel accomplishment) olmak üzere üç ayrı boyutta ele alınabilir (Ergin, 1992). Duygusal tükenme tükenmişliğin ilk başlangıcı olarak düşünülebilir. Bu aşamada çalışan enerji eksikliği, isteksizlik, yetersizlik hissedecektir. Duyarsızlaşma boyutunda çalışan hizmet verdiği insanları veya çalışma arkadaşlarını bireyden çok nesne gibi algılamakta, negatif, alaycı, katı tutumlar içerisine girebilmektedir. Kişisel başarısızlık boyutunda, üretkenlikte azalma, kendini başarısız bulma, moralsizlik, kişilerle iletişimden kaçınma durumları görülebilir (Maslach ve Jackson, 1981; Kurçer, 2005).

$\mathrm{Bu}$ araştırmalar ışığında, öğretmenlerin, MEB personelinin iş doyumu düzeyleri bir bakıma personelin tükenmişlik, işteki başarılarını ve performanslarını ortaya koymada ciddi bir göstergedir. Günümüze kadar motivasyon, tükenmişlik ve iş doyumu konusunda yurt içinde ve yurt dişında yapılmış olan çeşitli araştırmalar bulunmaktadır (Eryılmaz, 1987; Kinman \& Kinman, 2001; Türe, 1993; Sabanc1, 1994; Çetinkanat, 2000; Kuruoglu, 1995; Sancar, 1996; Rowley, 1996; Özsüer, 2016). Sabancı (1994), tarafindan yapılan araştırmada çift yönlü iletişimin, yönetilen ve yöneticiler açısından önemli olduğu ayrıca çalışanların iş doyumu ve motivasyonunu önemli ölçüde etkilediği sonucuna ulaşılmıştır. Rowley (1996), "Motivation and Academic Staff in Higher Education" isimli çalışması sonucunda motivasyonu en çok etkileyen değişkenlerin ekonomik ödüller, öğrenme kültürü ve yüksek eğitim, personelin tecrübesi ve rollerin farkl1lığı, kişisel özerklik ve örgüt kültürü olduğunu tespit etmiştir. İş doyumu, çalışanların işleriyle ilgili psikolojik sağlıklarına yönelik önemli bir kavramdır. Yapılan bazı çalışmalarda ise cinsiyet bağımsız değişkeninin iş doyumu açısından önemli bir değişken olmadığı, kadın ve erkeklerin benzer iş doyumu özelliklerine sahip olduklarına ilişkin bulgular ortaya çıkmıştır (Sağır, 2016; Kılıç, 2011; Tüzemen, 2004; Çekiç, 2017). Kıdem bağımsız değişkeni açısından yapılan karşılaştırmalarda ise kıdem arttıkça iş doyumunun azaldığına ilişkin sonuçlar ortaya çıkmıştır (Acar, 2016). Demografik değişkenler olan yaş, cinsiyet, medeni durum, kıdem ve eğitim düzeyi gibi demografik değişkenler öğretmenlerin iş tatmini ve motivasyonu ile ilgili olup motivasyon üzerinde önemli rol oynarlar (Bogler, 2002).

İlgili literatür ve yapılan çalışmalar incelendiğinde çeşitli sektörlerde pek çok araştırma yapıldığı ve bunlar içinde eğitim sektöründe öğretmen ve okul yöneticileri odaklı araştırmaların da yer aldığı belirlenmiştir. Ancak MEB Merkez Teşkilatı odaklı yeterince araştırma olmadığı dikkati çekmektedir. Ayrıca iş doyumuna ilişkin incelenen araştırmalar ve sonuçlarından hareket edilecek olursa iş doyumunda cinsiyet ve kıdemin önemli göstergeler olduğu ve MEB personelinin iş doyumunun bu değişkenler açısından incelenmesinin faydalı olacağı düşünülmüştür. Millî Eğitim Bakanlığı (MEB) bakanlıklar içerisinde eğitime yön verme özelliği ile tartışmasız en önemlilerinden biri olarak yer almaktadır. Bu denli önemli bir kurumun çalışanlarına verdiği önem, sağladığı çalışma koşulları, personelin motivasyonu gibi pek çok başlık da beraberinde önem kazanmaktadır. MEB Merkez Teşkilatında personelin iş doyumu düzeyinin bilinmesi gerek mevcut durumun ortaya çıkarılması açısından gerekse taşra teşkilatlarındaki MEB çalışanlarının iş doyumuna dolaylı etkisini ortaya koyması 
açısından oldukça önemli bir boyuttur. $\mathrm{Bu}$ araştırmada MEB personelinin iş doyumuna bakılarak literatüre ve bakanlık yöneticilerine yol gösterecek önemli sonuçlara ulaşılacağı düşünülmektedir.

\section{Araştırmanın Amacı}

Araştırmanın genel amacı MEB personelinin iş doyumunu belirlemektir. $\mathrm{Bu}$ genel amaca dayalı olarak aşağıdaki sorulara cevap aranmıştır.

Araştırmaya katılan personelin;

1. Ölçeğin bütünü dikkate alındığında iş doyum düzeyleri ne durumdadır?

2. Cinsiyetleri ile iş doyum düzeyleri arasında anlamlı bir ilişki var mıdır?

3. Mesleki kıdemleri ile iş doyum düzeyleri arasında anlamlı bir ilişki var mıdır?

\section{Sinırlılıklar}

$\mathrm{Bu}$ araştırma sonuçları ölçeklere katılım sağlayan MEB'in bir genel müdürlüğünde görevli ve araştırmaya katılan personelin görüşleri ile sınırlıdır.

\section{Yöntem}

\section{Araștırma Modeli}

Araştırma tarama modeline dayalı olarak tasarlanmıştır. Bilindiği gibi tarama modeli bir grubun çeşitli özelliklerini belirlemek için gerekli verilerin toplanmasını kapsamaktadır. Başlıca avantajı ise, araştırmaya katılan bireylerin çeşitli özelliklerine ilişkin gerekli bilgilerin elde edilmesine olanak sağlar (Büyüköztürk, Çakmak, Akgün, Karadeniz, ve Demirel, 2010, s. 16-17). Buna göre bu araştırmada MEB personelinin iş doyumu tekil tarama modeline göre, söz konusu personelin cinsiyet, iş yeri unvanı, çalışmakta olduğu genel müdürlük, mesleki kıdem, mezuniyet durumu bağımsız değişkenlere göre görüşleri arasındaki farklılıklar ise ilişkisel tarama modeline göre betimlenmeye çalışılmıştır.

\section{Çalışma Evreni ve Örneklem}

Araştırmanın çalışma evrenini, MEB'na bağlı bir genel müdürlük çalışanları oluşturmaktadır. Söz konusu personelin tamamı çalışmaya katıldığından örneklem seçilmemiş, araştırma çalışma evreni üzerinde yürütülmüştür. Araştırmanın çalışma evrenini 166 katılımcı oluşturmaktadır.

\section{Veri Toplama Aracı}

Araştırmada veri toplama aracı olarak Ünsal ve Özalp Türetgen (2005) tarafindan geliştirilen "Beyaz Yakalı Çalışanlar İçin İş Doyumu Ölçeği” ölçeği kullanılmıştır. Ölçeğin geliştirildiği ilk örneklem grubununun özelliklerini özetlemek gerekirse örneklem grubu farklı sektörlerde ve değişik işletmelerde görev yapan 694 beyaz yakalı çalışan oluşturmaktadır. Hem devlet hem de kamu sektöründen olan katılımcılar, üretim, hizmet, eğitim, finans, sağlık gibi çeşitli alanlarda çalışmaktadırlar. Katılımcıların \%58,1 ‘i kadın, \%41,9’u ise erkektir. Ayrıca örneklem grubunun yaş dağılımları incelendiğinde katılımcıların \%19,2'sinin 25 yaş altında, \%50,5'inin 25-34 yaş arasında, \%21,4'ünün 35-44 yaş arasında, \%8,9'unun ise 45 yaş üzerinde kişilerden oluşmaktadır. Örneklem grubunun \%20,8'i ortaöğretim, \% 60,3'ü yüksek öğretim ve \%18,9'u lisansüstü eğitim mezunudur. Ayrıca katılımcıların \%54,9’u evli, \%41,2’si bekar ve \%3,9’u eşlerinden ayrıdır.

Ölçek 35 maddeden ve 4 boyuttan oluşmaktadır. Bunlar: 1) Yönetim ve politika uygulamaları, 2) İşin yapısı, 3) İletişim ve ilişkiler, 4) Fiziksel çalışma koşulları boyutlarıdır. Ölçekte yer alan maddelerin açımlayıcı faktör analizi (AFA) sonuçlarına göre faktör yükleri 0,37 ile 0,74 arasında değişmektedir. Ölçeğin bütününe ait cronbach alpha güvenirlik katsayısı 0,89 olup, alt boyutların güvenirlik katsayıları ise 1. boyut $=0,88$, 2. boyut $=0,75,3$. boyut $=0,67$, 4. boyut $=0,66$ dır. Ölçek $3=$ Evet, $2=$ Kısmen, $1=$ Hayır biçiminde sinıflamalı ölçek formu biçiminde hazırlanmış olup, katılımcıların söz konusu kategorilerdeki frekans oranlarına göre işdoyum düzeyleri yorumlanabilmektedir.

\section{Verilerin Çözümlenmesi}


Verilerin istatistiksel analizlerinde bilgisayar paket programı (SPSS) kullanılmıştır.

Araştırmaya katılan personelin cinsiyet, iş yeri unvanı, mesleki kıdem, mezuniyet durumu gibi bağımsız değişkenlere ilişkin özellikleri frekans ve yüzde oranları belirlenerek çözümlenmiştir. Bağımsız değişkenlerden cinsiyet ve kıdem değişkenlerinin iş doyumu açısından önemli bir değişken olup olmadığı kay kare analizi ile test edilmiştir. Araştırmada kullanılan iş doyumu ölçeği sınıflama ölçeği biçimine daha uygun özellik gösterdiği için bağımsız değişkenlere göre yapılan karşılaştırmalı analizlerde kay kare kullanım koşullarının sağlandığı hallerde kay kare çözümlemesi yapılmıştır. Ölçeğin her bir maddesine kay kare kullanılmasının nedeni ise iş doyumu açısından ölçekteki her bir maddenin kendi başına ayrı bir anlam bütünlüğü taşıyabileceği ve araştırma bulgularına farklı bir bakış açısı katabileceği yönündeki düşünceden kaynaklanmıştır.

\section{Bulgular}

Araştırma sonucunda elde edilen bulgular araştırmanın alt amaçları bağlamında ele alınarak yorumlanmıştır.

\section{Demografik Özellikler}

Araştırmaya katılanların demografik özellikleri Tablo 1'de görülmektedir.

Tablo 1. Katılımcıların Demografik Özellikleri

\begin{tabular}{|c|c|c|c|}
\hline ÖZELLİKLER & & $\mathbf{f}$ & $\%$ \\
\hline \multicolumn{4}{|l|}{ Cinsiyet } \\
\hline Kadın & & 92 & 55,4 \\
\hline \multirow[t]{2}{*}{ Erkek } & & 74 & 44,6 \\
\hline & Toplam & 166 & 100,0 \\
\hline \multicolumn{4}{|l|}{ Kıdem } \\
\hline $1-10$ yıl & & 37 & 22,3 \\
\hline $11-20 \mathrm{y} 1 \mathrm{l}$ & & 67 & 40,4 \\
\hline \multirow[t]{2}{*}{21 yıl ve üzeri } & & 62 & 37,3 \\
\hline & Toplam & 166 & 100,0 \\
\hline
\end{tabular}

\section{Mezuniyet Durumu}

Lisans öncesi (İlk-orta-lise-önlisans)

Lisans

Lisansüstü (Yük.lisans - doktora)

47

\section{Unvan}


Öğretmenler

Genel İdari Hizmetler Personeli ve Diğerleri

44

26,5

Toplam

166

100,0

Araştırmaya katılan genel müdürlükten 166 personelin \%55,4'ünü kadınlar, \%44,6'sını erkekler oluşturmaktadır. Katılımcılar kıdem yılları açısından incelendiğinde ilk sırayı \%40,4 ile 11-20 yıl kıdemi olanlar, ikinci sırayı \%37,3 ile 21 yıl ve üzeri kıdemi olanlar alıken bunu \%22,3 ile 1-10 yıl arası k1demi olan personeller almaktadır. Mezuniyet durumları açısından incelendiğinde ilk sırada \%60,2 ile Lisans mezunları, ikinci sırada \%28,3 ile Lisansüstü (Yüksek lisans ve doktora) mezunları, üçüncü sırada ise \%11,4 ile Lisans öncesi (Illk-orta-lise-önlisans) mezunları yer almaktadır. Katılımcılara unvanları açısından bakıldığında öğretmenler \%60,8 ile ilk sırada yer alırken, çalışanların yaklaşık dörtte biri $(\% 26,5)$ genel idari hizmetler personeli ve diğerleri grubunda yer almaktadır. Yönetici, milli eğitim uzmanı ve uzman yardımcısı konumunda olanlar ise \%12,7 ile üçüncü sırada yer almaktadır. Araştırmaya katılan personelin demografik özelliklerine genel olarak bakıldığında, personelin çoğunluğunun kadınlardan oluştuğu, kıdem açısından büyük çoğunluğun 11-20 yıl arası kıdeme sahip olduğu ve lisans mezunlarının çoğunlukta olduğu ve unvan açısından büyük çoğunluğun öğretmenlerden oluştuğu görülmektedir.

\section{Personelin iş doyumu nitelikleri}

Araştırmaya katılan genel müdürlük personelinin iş doyumuna ilişkin özellikleri incelenmiş ve veriler Tablo 2'de sunulmuştur.

Tablo 2. Katılımcıların İş Doyumu Özellikleri

\begin{tabular}{llllllllll}
\hline No* $^{*}$ & Maddeler & & 3 & & 2 & & 1 \\
\hline & & f & $\%$ & f & $\%$ & f & $\%$
\end{tabular}

\section{İşin Yapısı}

2 İşimde yaratıcılığımı istediğim kadar kullanamam.

68

41,0

45

$27,1 \quad 53$

31,9

7

İşim birbirinden farklı türde görevler içermesi

bakımından çeşitlidir.

$\begin{array}{cccccc}135 & 81,3 & 9 & 5,4 & 22 & 13,3 \\ 97 & 58,4 & 42 & 25,3 & 27 & 16,3 \\ 92 & 55,4 & 31 & 18,7 & 43 & 25,9 \\ 45 & 27,1 & 49 & 29,5 & 72 & 43,4 \\ 119 & 71,7 & 36 & 21,7 & 11 & 6,6 \\ 59 & 35,5 & 63 & 38,0 & 44 & 26,5 \\ 100 & 60,2 & 54 & 32,5 & 12 & 7,2\end{array}$

34 İşimin toplum içinde saygın bir yeri vardır.

\section{Fiziksel Çalışma Koşulları}

1 İşyerim tarafindan sağlanan yemek olanakları 
tatmin edicidir.

6 İşyerimde alınmış olan güvenlik tedbirleri (giriş çıkış güvenliği, yangın vb.) yeterlidir.

$\begin{array}{llllll}109 & 65,7 & 33 & 19,9 & 24 & 14,5 \\ 64 & 38,6 & 22 & 13,3 & 80 & 48,2 \\ 117 & 70,5 & 34 & 20,5 & 15 & 9,0 \\ 88 & 53,0 & 45 & 27,1 & 33 & 19,9 \\ 116 & 69,9 & 37 & 22,3 & 13 & 7,8 \\ 130 & 78,3 & 25 & 15,1 & 11 & 6,6\end{array}$

\section{Yönetim Politika ve Uygulamaları}

3 İşyerimde terfi sistemi yeterince açık ve adaletli şekilde uygulanır.

İşyerimde çalışanlar objektif biçimde değerlendirilirler.

$\begin{array}{llllll}49 & 29,5 & 66 & 39,8 & 51 & 30,7 \\ 93 & 56,0 & 42 & 25,3 & 31 & 18,7 \\ 63 & 38,0 & 64 & 38,6 & 39 & 23,5 \\ 88 & 53,0 & 50 & 30,1 & 28 & 16,9\end{array}$

İşyerimde işimi yapıp yapmadığım konusunda yapıcı geribildirim verilir.

10 İşyerimde başarılarım yazılı veya sözlü olarak takdir edilir.

$\begin{array}{llllll}34 & 20,5 & 64 & 38,6 & 68 & 41,0\end{array}$

İşyerimde üstüm çalışanlar arasında ayrımcılık yapar. İşyeri içerisinde arzu edilen ve edilmeyen
davranışlar açık olarak belirlenmiştir.

$\begin{array}{llllll}74 & 44,6 & 61 & 36,7 & 31 & 18,7\end{array}$

18 İşyeri yönetimi güvene dayalı, şeffaf ve açık ilişskiler kurulmasını destekler.

$\begin{array}{llllll}73 & 44,0 & 67 & 40,4 & 26 & 15,7\end{array}$

21 Bu işletmede çalışmayı arkadaşlarıma da tavsiye ederim.

İşimle ilgili getirdiğim iyileştirme önerilerim dikkate alınır.

\section{8}

27 İşyerimde amaçlar açık, kesin ve belirgindir.

$\begin{array}{llllll}87 & 52,4 & 60 & 36,1 & 19 & 11,4\end{array}$

29 İşyerim iyi elemanları işten çıkarmaktan kaçınır. $\quad \begin{aligned} & 76 \\ & 26\end{aligned} \quad 45,8 \quad 59 \quad 35,5 \quad 31 \quad 18,7$

32 İşyerindeki çalışma ortamımız genellikle eğlencelidir.

$\begin{array}{llllll}66 & 39,8 & 56 & 33,7 & 44 & 26,5\end{array}$ 
35 İşyerimde çalışanlara değer verildiğini düşünüyorum.

\section{İletişim ve İlişkiler}

4 İşimde neler yapmam gerektiğinden haberdarım.

9 Üstlerimle olan ilişkilerim sorunludur.

14

19

28

Işimle ilgili zorlandığım konuları üstüme rahatlıkla söylerim.

Çalışma arkadaşlarımla olan ilişkilerimden memnunum.

Çalışma arkadaşlarımla olan problemleri çözmekte zorlanırım.

Çalışma arkadaşlarımdan, işimi yaparken zorlandığım konularda yardım alabilirim.

33

İşimi yaparken diğer çalışanlarla iletişim kopukluğu yaşıyorum.

$\begin{array}{llllll}129 & 77,7 & 26 & 15,7 & 11 & 6,6 \\ 144 & 86,7 & 19 & 11,4 & 3 & 1,8 \\ 130 & 78,3 & 28 & 16,9 & 8 & 4,8 \\ 129 & 77,7 & 28 & 16,9 & 9 & 5,4 \\ 140 & 84,3 & 19 & 11,4 & 7 & 4,2 \\ & & & & & \\ 122 & 73,5 & 32 & 19,3 & 12 & 7,2 \\ 112 & 67,5 & 34 & 20,5 & 20 & 12,0\end{array}$

*Madde numaraları ölçekteki sıra numaralarıdır.

Araştırmaya katılan Genel Müdürlük personelinin iş doyumu özelliklerine ilişkin bulguların elde edildiği ölçeğin alt boyutları dikkate alınarak özetlenmiştir. Buna göre bulgular aşağıda sunulmuştur.

\section{İşin Yapısı}

Araştırmaya katılan genel müdürlük personelinin büyük çoğunluğunu oluşturan \%81,3'lük kesim işinin birbirinden farklı türde görevler içerdiğini belirtirken, \%60,2'si işinin toplumda saygın bir yeri olduğunu belirtmektedir. Yeteneklerine uygun bir işte çalıştığını düşünenlerin oranı yarıdan \%58,4 iken, işini monoton bulanların oranı \%55,4'tür. Araştırmaya katılanların beşte ikisi (\%41) işinde yaratıcılığını kullanabildiğini, \%43,4'ü işlerini yaparken kendi başlarına karar alıp uygulayamadıklarını, \%38'i yeterli parası olsa idi işini bırakıp bırakmama konusunda kararsız olduklarını belirtmişlerdir. Genel olarak bir değerlendirme yapmak gerekirse çalışanlar çoğunlukla işlerinde yaratıcılıklarını kullanabilme ve işlerinin toplumdaki yerinin saygınlığı ve yeteneklerine uygun işte çalışma konusunda olumlu düşünmekle beraber, üçte birlik kesimin işlerinin saygınlığı ve yeteneklerine uygun işte çalışma konusunda yeterince olumlu düşünmedikleri dikkate değer bir bulgudur. Ayrıca çalışanlar çoğunlukla kendi başlarına karar alıp uygulayamamakta, işlerini monoton bulmaktadır.

\section{Fiziksel Çalıșma Koşulları}

Araştırmaya katılanların \% 73,5'i sağlanan yemek olanaklarını tatmin edici bulurken, işyerinde alınmış güvenlik önlemlerini yeterli bulanlar \% 65,7, işyerinde rahatsız edici oranda gürültü olduğunu ifade edenlerin oranı ise \%70,5 olarak belirlenmiştir. Ayrıca katılımcıların yaklaşık üçte ikisi $(\% 69,9)$ işyerinde temizlik kurallarına dikkat edildiğini belirtirken, \%78,3’ü işyerinde aydınlanma koşullarını yeterli bulmaktadır. İşyerinde yaptığı iş karşılığı aldığı ücreti tatmin edici bulanların oranı yarıya yakın $(\% 48,2)$ iken yine katılımcıların yaklaşı yarısı $(\% 53)$ işyerinin iş için gerekli malzemeleri en kısa sürede temin ettiğini düşünmektedir. Genel olarak bir değerlendirme yapmak gerekirse işyerinde yemek, güvenlik önlemleri, temizlik, 1şıklandırma vb. durumlar genelde olumlu, gürültü açısından ise olumsuz bir ortam olduğu söylenebilir. Ancak bu görüşlere doğrudan katılmayan üçte birlik bir kesimin olduğu da dikkate alınması gereken bir orandır. Verilen ücretlerde genel olarak yetersiz bulunmaktadır.

Yönetim Politika ve Uygulamaları 
Katılımcıların \%41'i işyerlerinde terfi sisteminin açık ve adaletli uygulanmadığını belirtmiştir. İşyerinde çalışanların objektif değerlendirilip değerlendirilmediği sorusuna katılımcıların \%30,7'si objektif değerlendirme olmadığını belirtmiştir. Çalışma ortamını eğlenceli bulanların oranı \%39,8'dir. Üstlerinin çalışanlar arası ayrımcılık yaptığını belirten katılımcı oranı yarıdan fazladır (\%53). Araştırmaya katılanların yarıdan fazlası (\%56) işlerine dönük yapıcı geribildirim aldıklarını belirtmiştir. İş başarılarının yazılı veya sözlü olarak takdir edilip edilmeme sorusuna çekimser kalarak yanıt vermeyen katılımcı oranı \%38,6 iken \%38'i de takdir edildiklerini belirtmiştir. İşyerinde arzu edilen ve edilmeyen davranışların açık olarak belirlendiğini düşünen katılımcıların oranı \%44,6'dır. Katılımcılar işyerlerinde yönetimin güvene dayalı, şeffaf ve açık ilişkiler kurulmasını destekleme oranlarını \%44 olarak belirtmiştir. Çalışanların \%47,6'sı işyerinde çalışanlara değer verildiğini belirtmiştir. Kurumumda çalışmayı arkadaşlarıma tavsiye ederim diyen katılımcıların oranı yarıdan fazladır $(\% 52,4)$. İş ile ilgili getirdiği önerilerin dikkate alındığını belirten katılımcı oranı \%50,6 iken işyerindeki amaçların açık, kesin ve belirgin olduğunu belirtenler \%52,4'dür. Genel olarak bir değerlendirme yapmak gerekirse işyerinde açık ve adaletli bir terfi sistemi olmadığı, çalışanların değerlendirilmesinde objektif davranılmadığı, üstlerin çalışanlar arası ayrımcılık yaptığı, çalışanların çalışma ortamını eğlenceli bulmadığı söylenebilir. Bunun yanı sıra çalışanlar işlerine dönük yapıcı geribildirim almakta, çalışanlar kurumda çalışmayı arkadaşlarına tavsiye etmekte, çalışanların işle ilgili önerileri dikkate alınmaktadır. Ancak pek çok maddede yanıt vermekten kaçınan katılımcı oranlarının da yüksekliği dikkat çekmektedir.

\section{İletişim ve İlişkiler}

Araştırmaya katılanların \%77,7’si işinde neler yapması gerektiğinden haberdar olduğunu, \%78,3'ü de çalışma arkadaşlarıyla ilişkilerinden memnun olduğunu belirtmiştir. Ayrıca katılımcıların \%84,3’ü işinde zorlandığı konularda iş arkadaşlarından yardım alabildiğini, \%73,5'i de üstlerine işte zorlandığı konuları rahatlıkla söylediğini belirtmiştir. Üstleriyle ilişkilerinin sorunlu olduğunu belirten katılımcı oranı \%86,7 iken, çalışma arkadaşlarıyla problemlerini çözmekte zorlananların oranı \%77,7'dir. Ayrıca katılımcıların \%67,5'i işini yaparken diğer çalışanlarla iletişim kopukluğu yaşadığını belirtmiştir. Genel olarak bir değerlendirme yapmak gerekirse çalışanlar işlerinde ne yapması gerektiğinden haberdar, çalışma arkadaşlarıyla ilişkilerinden memnun, zorlandığı konularda iş arkadaşlarından yardım alabilmekte ve üstlerine işle ilgili zorlandıkları konuları rahatlıkla söyleyebilmektedir. Ancak genel olarak katılımcıların üstleri ile ilişkilerinin sorunlu olduğu, çalışma arkadaşları ile problemlerini çözmekte sorun yaşadıkları, iş yaparken diğer çalışanlarla işletişim kopukluğu yaşadı̆̆ı da söylenebilir.

Araştırmada katılımcıların iş doyumu özellikleri cinsiyet bağımsız değişkeni dikkate alınarak karşılaştırılmıştır. Elde edilen veriler Tablo 3'te görülmektedir.

Tablo 3. Cinsiyete Göre Katılımcıların İş Doyumu Özellikleri

\begin{tabular}{|c|c|c|c|c|c|c|c|c|c|c|}
\hline \multirow[t]{2}{*}{$\begin{array}{c}\text { Madde } \\
\text { No }\end{array}$} & \multirow[t]{2}{*}{ Cinsiyet } & \multicolumn{2}{|c|}{3} & \multicolumn{2}{|c|}{2} & \multicolumn{2}{|c|}{1} & Toplam & $X^{2}$ & $\mathrm{p}$ \\
\hline & & $\mathrm{f}$ & $\%$ & $\mathrm{f}$ & $\%$ & $f$ & $\%$ & $\%$ & & \\
\hline
\end{tabular}

\section{İsin Yapısı}

\begin{tabular}{|c|c|c|c|c|c|c|c|c|c|c|}
\hline Kadın & 39 & 42,4 & 21 & 22,8 & 32 & 34,8 & 92 & 100,0 & \multirow[b]{2}{*}{2,026} & \multirow[b]{2}{*}{0,363} \\
\hline Erkek & 29 & 39,2 & 24 & 32,4 & 21 & 28,4 & 74 & 100,0 & & \\
\hline Kadın & 74 & 80,4 & 4 & 4,3 & 14 & 15,2 & 92 & 100,0 & \multirow{2}{*}{1,060} & \multirow{2}{*}{0,589} \\
\hline Erkek & 61 & 82,4 & 5 & 6,8 & 8 & 10,8 & 74 & 100,0 & & \\
\hline Kadın & 55 & 59,8 & 23 & 25,0 & 14 & 15,2 & 92 & 100,0 & \multirow{2}{*}{0,211} & \multirow{2}{*}{0,900} \\
\hline Erkek & 42 & 56,8 & 19 & 25,7 & 13 & 17,6 & 74 & 100,0 & & \\
\hline
\end{tabular}




\begin{tabular}{|c|c|c|c|c|c|c|c|c|c|c|c|}
\hline \multirow[b]{2}{*}{17} & Kadın & 49 & 53,3 & 17 & 18,5 & 26 & 28,3 & 92 & 100,0 & \multirow[b]{2}{*}{0,621} & \multirow[b]{2}{*}{0,733} \\
\hline & Erkek & 43 & 58,1 & 14 & 18,9 & 17 & 23,0 & 74 & 100,0 & & \\
\hline \multirow{2}{*}{22} & Kadın & 20 & 21,7 & 26 & 28,3 & 46 & 50,0 & 92 & 100,0 & \multirow{2}{*}{4,395} & \multirow{2}{*}{0,111} \\
\hline & Erkek & 25 & 33,8 & 23 & 31,1 & 26 & 35,1 & 74 & 100,0 & & \\
\hline \multirow{2}{*}{26} & Kadın & 65 & 70,7 & 22 & 23,9 & 5 & 5,4 & 92 & 100,0 & \multirow{2}{*}{0,945} & \multirow{2}{*}{0,624} \\
\hline & Erkek & 54 & 73,0 & 14 & 18,9 & 6 & 8,1 & 74 & 100,0 & & \\
\hline \multirow[b]{2}{*}{31} & Kadın & 31 & 33,7 & 36 & 39,1 & 25 & 27,2 & 92 & 100,0 & \multirow[b]{2}{*}{0,308} & \multirow[b]{2}{*}{0,857} \\
\hline & Erkek & 28 & 37,8 & 27 & 36,5 & 19 & 25,7 & 74 & 100,0 & & \\
\hline \multirow{2}{*}{34} & Kadın & 54 & 58,7 & 34 & 37,0 & 4 & 4,3 & 92 & 100,0 & \multirow{2}{*}{3,695} & \multirow{2}{*}{0,158} \\
\hline & Erkek & 46 & 62,2 & 20 & 27,0 & 8 & 10,8 & 74 & 100,0 & & \\
\hline
\end{tabular}

Fiziksel Çalışma Koşulları

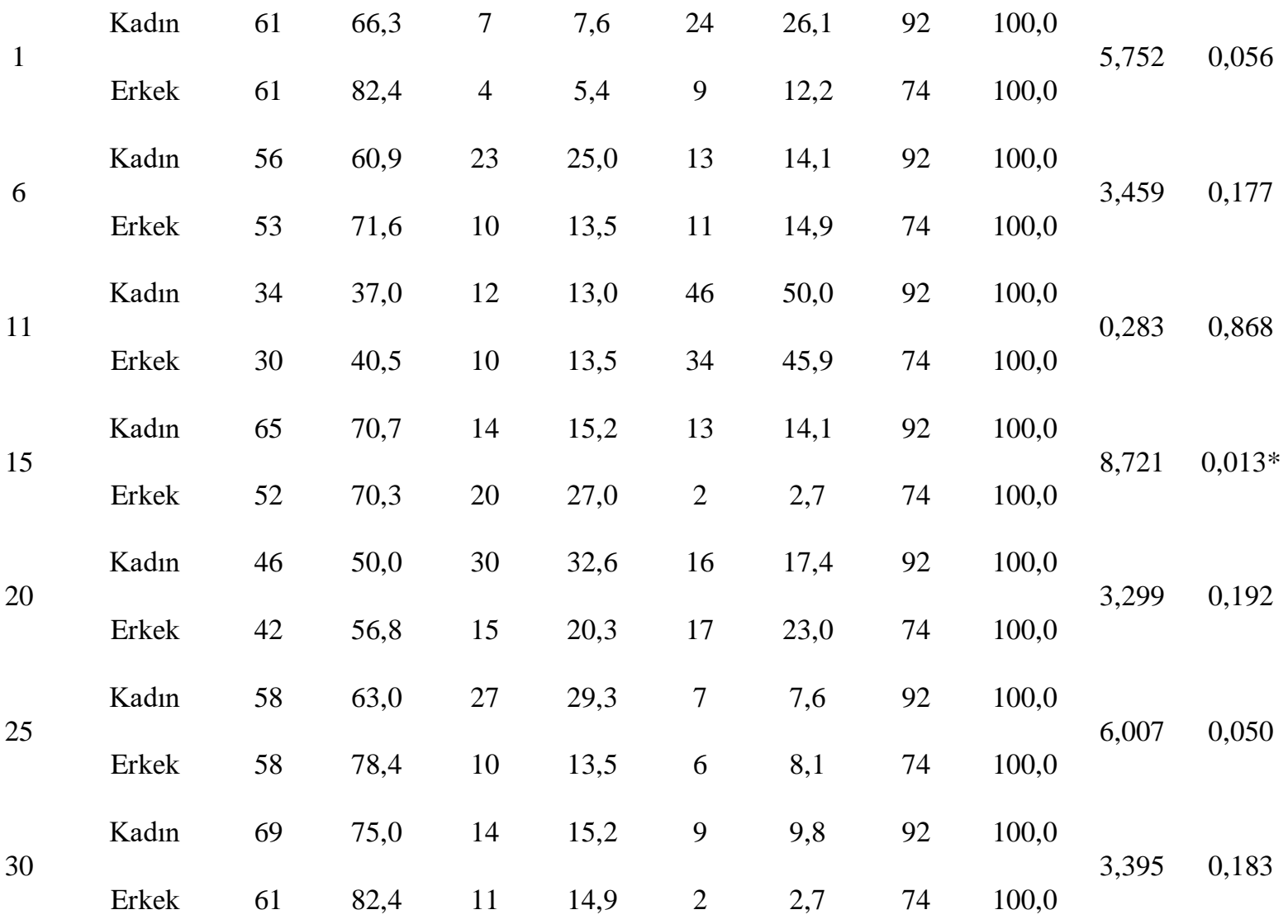

\section{Yönetim Politika ve Uygulamaları}

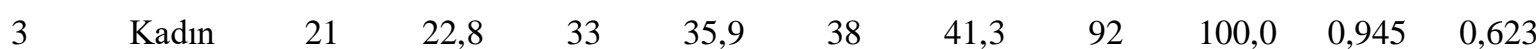




\begin{tabular}{|c|c|c|c|c|c|c|c|c|c|c|c|}
\hline & Erkek & 13 & 17,6 & 31 & 41,9 & 30 & 40,5 & 74 & 100,0 & & \\
\hline \multirow[b]{2}{*}{5} & Kadın & 27 & 29,3 & 37 & 40,2 & 28 & 30,4 & 92 & 100,0 & \multirow[b]{2}{*}{0,019} & \multirow[b]{2}{*}{0,991} \\
\hline & Erkek & 22 & 29,7 & 29 & 39,2 & 23 & 31,1 & 74 & 100,0 & & \\
\hline \multirow{2}{*}{8} & Kadın & 50 & 54,3 & 25 & 27,2 & 17 & 18,5 & 92 & 100,0 & \multirow{2}{*}{0,394} & \multirow{2}{*}{0,821} \\
\hline & Erkek & 43 & 58,1 & 17 & 23,0 & 14 & 18,9 & 74 & 100,0 & & \\
\hline \multirow{2}{*}{10} & Kadın & 36 & 39,1 & 35 & 38,0 & 21 & 22,8 & 92 & 100,0 & \multirow{2}{*}{0,129} & \multirow{2}{*}{0,938} \\
\hline & Erkek & 27 & 36,5 & 29 & 39,2 & 18 & 24,3 & 74 & 100,0 & & \\
\hline \multirow{2}{*}{13} & Kadın & 47 & 51,1 & 33 & 35,9 & 12 & 13,0 & 92 & 100,0 & \multirow{2}{*}{4,198} & \multirow{2}{*}{0,123} \\
\hline & Erkek & 41 & 55,4 & 17 & 23,0 & 16 & 21,6 & 74 & 100,0 & & \\
\hline \multirow[b]{2}{*}{16} & Kadın & 40 & 43,5 & 36 & 39,1 & 16 & 17,4 & 92 & 100,0 & \multirow[b]{2}{*}{0,557} & \multirow[b]{2}{*}{0,757} \\
\hline & Erkek & 34 & 45,9 & 25 & 33,8 & 15 & 20,3 & 74 & 100,0 & & \\
\hline \multirow{2}{*}{18} & Kadın & 38 & 41,3 & 37 & 40,2 & 17 & 18,5 & 92 & 100,0 & \multirow{2}{*}{1,381} & \multirow{2}{*}{0,501} \\
\hline & Erkek & 35 & 47,3 & 30 & 40,5 & 9 & 12,2 & 74 & 100,0 & & \\
\hline \multirow{2}{*}{21} & Kadın & 47 & 51,1 & 34 & 37,0 & 11 & 12,0 & 92 & 100,0 & \multirow{2}{*}{0,743} & \multirow{2}{*}{0,690} \\
\hline & Erkek & 40 & 54,1 & 23 & 31,1 & 11 & 14,9 & 74 & 100,0 & & \\
\hline \multirow{2}{*}{23} & Kadın & 43 & 46,7 & 38 & 41,3 & 11 & 12,0 & 92 & 100,0 & \multirow{2}{*}{1,267} & \multirow{2}{*}{0,531} \\
\hline & Erkek & 41 & 55,4 & 25 & 33,8 & 8 & 10,8 & 74 & 100,0 & & \\
\hline \multirow{2}{*}{27} & Kadın & 44 & 47,8 & 36 & 39,1 & 12 & 13,0 & 92 & 100,0 & \multirow{2}{*}{1,797} & \multirow{2}{*}{0,407} \\
\hline & Erkek & 43 & 58,1 & 24 & 32,4 & 7 & 9,5 & 74 & 100,0 & & \\
\hline \multirow{2}{*}{29} & Kadın & 41 & 44,6 & 32 & 34,8 & 19 & 20,7 & 92 & 100,0 & \multirow{2}{*}{0,533} & \multirow{2}{*}{0,766} \\
\hline & Erkek & 35 & 47,3 & 27 & 36,5 & 12 & 16,2 & 74 & 100,0 & & \\
\hline & Kadın & 33 & 35,9 & 31 & 33,7 & 28 & 30,4 & 92 & 100,0 & & \\
\hline 32 & & & & & & & & & & 1,987 & 0,370 \\
\hline & Erkek & 33 & 44,6 & 25 & 33,8 & 16 & 21,6 & 74 & 100,0 & & \\
\hline & Kadın & 41 & 44,6 & 36 & 39,1 & 15 & 16,3 & 92 & 100,0 & & \\
\hline 35 & Erkek & 38 & 51,4 & 19 & 25,7 & 17 & 23,0 & 74 & 100,0 & & $0,16 /$ \\
\hline
\end{tabular}

\section{İletișim ve İlișkiler}




\begin{tabular}{|c|c|c|c|c|c|c|c|c|c|c|c|}
\hline \multirow{2}{*}{4} & Kadın & 68 & 73,9 & 19 & 20,7 & 5 & 5,4 & 92 & 100,0 & \multirow{2}{*}{4,106} & \multirow{2}{*}{0,128} \\
\hline & Erkek & 61 & 82,4 & 7 & 9,5 & 6 & 8,1 & 74 & 100,0 & & \\
\hline \multirow{2}{*}{9} & Kadın & 82 & 89,1 & 8 & 8,7 & 2 & 2,2 & 92 & 100,0 & \multirow{2}{*}{$\cdots$} & \multirow{2}{*}{$\cdots$} \\
\hline & Erkek & 62 & 83,8 & 11 & 14,9 & 1 & 1,4 & 74 & 100,0 & & \\
\hline \multirow{2}{*}{14} & Kadın & 70 & 76,1 & 17 & 18,5 & 5 & 5,4 & 92 & 100,0 & \multirow{2}{*}{$\ldots$} & \multirow{2}{*}{$\cdots$} \\
\hline & Erkek & 60 & 81,1 & 11 & 14,9 & 3 & 4,1 & 74 & 100,0 & & \\
\hline \multirow{2}{*}{19} & Kadın & 68 & 73,9 & 19 & 20,7 & 5 & 5,4 & 92 & 100,0 & \multirow{2}{*}{$\ldots$} & \multirow{2}{*}{$\ldots$} \\
\hline & Erkek & 61 & 82,4 & 9 & 12,2 & 4 & 5,4 & 74 & 100,0 & & \\
\hline \multirow{2}{*}{24} & Kadın & 76 & 82,6 & 11 & 12,0 & 5 & 5,4 & 92 & 100,0 & \multirow{2}{*}{$\ldots$} & \multirow{2}{*}{$\cdots$} \\
\hline & Erkek & 64 & 86,5 & 8 & 10,8 & 2 & 2,7 & 74 & 100,0 & & \\
\hline \multirow{2}{*}{28} & Kadın & 66 & 71,7 & 20 & 21,7 & 6 & 6,5 & 92 & 100,0 & \multirow{2}{*}{0,878} & \multirow{2}{*}{0,645} \\
\hline & Erkek & 56 & 75,7 & 12 & 16,2 & 6 & 8,1 & 74 & 100,0 & & \\
\hline \multirow{2}{*}{33} & Kadın & 60 & 65,2 & 23 & 25,0 & 9 & 9,8 & 92 & 100,0 & \multirow{2}{*}{3,091} & \multirow{2}{*}{0,213} \\
\hline & Erkek & 52 & 70,3 & 11 & 14,9 & 11 & 14,9 & 74 & 100,0 & & \\
\hline
\end{tabular}

${ }^{*} \mathrm{p}<0,05$ anlamli $\quad \mathrm{N}=166$

Katılımcıların cinsiyetleri ile iş doyum düzeyleri arasında anlamlı bir ilişki olup olmadığı kay kare analizi ile test edilmeye çalışılmıştır. Kay kare işleminin kullanım koşullarının sağlandığı maddelerde karşılaştırma yapılabilmiş, koşulların sağlanamadığı 9, 14, 19, 24. Maddeler ise frekans ve yüzdelere dayalı olarak analiz yapılmıştır. Buna göre iş doyumu ölçeğinin boyutlarına göre cinsiyet değişkenine dayalı olarak elde edilen bulgular ve yorumlar aşağıda ele alınmıştır.

\section{İșin Yapısı}

İşin yapısı kapsamındaki tüm boyutlarda cinsiyete göre yapılan kay kare analizlerine göre cinsiyetin etkili bir değişken olmadığı, kadın ve erkek personelin benzer görüşlere sahip oldukları belirlenmiştir. En çok vurgulanan görüşler dikkate alınarak yapılan analize göre hem kadın hem de erkekler görevlerinin çeşitlilik gösterdiğini, yaptıkları işlerin kişisel gelişimlerine olumsuz etkisi olduğunu belirtmektedirler. Katılımcıların yaklaşı üçte ikisi (kadınlar $=\% 58,7$; erkekler $=\% 62,2$ ) işinin toplum içinde saygın bir yeri olduğunu belirtmekle beraber, azımsanmayacak oranda katılımcı (kadınlar=\%36,5; erkekler=\%37) yanıt vermekten kaçınmıştır. Yine grubun üçte ikisi yeteneklerine uygun bir işte çalıştığını belirtmekle beraber (kadınlar $=\% 59,8$; erkekler $=\% 56,8$ ), her iki grubun yaklaşık dörtte biri ise cevap vermekten kaçınmıştır. Katılımcıların yarıdan biraz fazlası işlerini monoton bulmakta, ancak yaklaşık dörtte biri monoton olmadığını ifade etmektedir. Bunun yanı sıra kendi başına karar alıp uygulayabilme, yaratıcılıklarını kullanabilme konusunda personelin çok da olumlu düşünmediği, maddi olanaklarının iyi olması halinde işi bırakabileceğini söyleyenlerin oranının dikkate değer ölçüde olduğu ortaya çıkmıştır.

Genel bir değerlendirme yapmak gerekirse, kurumda verilen görevler çeşitlilik gösterebilmekte, yapılan görevlerin personelin kişisel gelişimlerine yeterince katkısı olmamakta, yapılan görev genel olarak toplum içinde saygın olmakla beraber, genelde personelin yeteneklerine uygun bir işte çalıştığı ancak kendi başlarına karar verebilme, yaratıcılıklarını kullanabilme açısından çok da uygun ortam olmadığı söylenebilir. Ayrıca dikkate 
değer oranda yapılan işin monotonluğu ve maddi koşullar uygun olması halinde işin bırakılabileceği bulguları da dikkat çekicidir.

\section{Fiziksel Çalışma Koşulları}

İşyerinde rahatsız edici oranda gürültü olması konusu ile cinsiyet arasında anlamlı bir ilişki olduğu belirlenmiştir $\left(X^{2}=8,721 ; p<0,05\right.$; ilişki katsayısı=0,22). İlişki katsayısına göre düşük düzeyde bir ilişkinin olduğu bu konuda hem kadın hem de erkekler çoğunlukla rahatsız edici düzeyde gürültü bulunduğunu belirtmektedir (kadınlar $=\% 70,7$; erkekler $=\% 70,3)$. Ancak erkeklere göre $(\% 2,7)$ gürültünün olmadığını söyleyen kadınlar \%14,1 iken, yaklaşık olarak erkeklerin üçte birinin (\%27) bu konuda fikir beyan etmediği belirlenmiştir. Fiziksel çalışma koşullarının diğer boyutlarında cinsiyetin etkili bir değişken olmadığı, kadın ve erkek personelin benzer görüşlere sahip oldukları belirlenmiştir. Her iki grubun çoğunluğunun vurguladıkları görüşlere göre işyerinin aydınlanma koşulları ve yemek olanakları yeterli bulunmuş, temizlik kurallarına dikkat edildiği belirtilmiş, alınan güvenlik önlemleri uygun bulunmuştur. Kadınların yaklaşık dörtte birinin $(\% 26,1)$ yemekler konusunda olumsuz düşünmesi, yine kadınların yaklaşık üçte birinin temizlik kuralları konusunda $(\% 29,3)$, erkeklerin dörtte birinin de güvenlik önlemleri konusunda görüş belirtmemesi (\%25) dikkat çekicidir. Ancak yapılan iş için gerekli araç-gereçlerin kısa sürede sağlanması konusunda her iki grubun yaklaşı yarısı (kadınlar=\%50,0; erkekler=56,8) olumlu düşünmekle beraber, dikkate değer oranda katılımcının fikir beyan etmediği ya da olumsuz düşündükleri ortaya çıkmıştır. Diğer yandan her iki grubun yaklaşık yarısı (Kadınlar $=\% 50$, erkekler $=\% 45,9$ ) ücretleri tatmin edici bulmamaktadır. Genel olarak bir değerlendirme yapmak gerekirse cinsiyet bağımsız değişkenine göre gruplar benzer görüşleri ortaya koymaktadır. İşyerinde yemek olanakları, güvenlik önlemleri, temizlik, 1şıklandırma vb. durumlar genelde olumlu, gürültü açısından ise olumsuz bir ortam olduğu söylenebilir. Ancak bu görüşlere doğrudan katılmayan dikkate değer bir kesimin olduğu da dikkate alınması gereken bir orandır. Verilen ücretler de her iki grup tarafindan da genel olarak yetersiz bulunmaktadir.

\section{Yönetim Politika ve Uygulamaları}

Yönetim politika ve uygulamaları kapsamındaki tüm boyutlarda cinsiyete göre yapılan kay kare analizlerine göre cinsiyetin etkili bir değişken olmadığı, kadın ve erkek personelin benzer görüşlere sahip oldukları belirlenmiştir. En çok vurgulanan görüşler dikkate alınarak yapılan analize göre her iki grup da görevler işyerinde terfi sisteminin yeterince açık ve adaletli uygulanmadığını belirtirken (kadınlar=\% 41,3 ; erkekler $=\% 40,5$ ). Erkeklerin \%41,9'unun kadınların ise \%35,9'unun görüş bildirmemesi dikkat çekicidir. İşyerlerinde çalışanların objektif değerlendirilme durumlarına her iki grubun yaklaşık üçte biri olumlu cevap verirken, yaklaşık üçte biri de olumsuz cevap vermişler geriye kalanları da cevap vermemişlerdir. Kadınların $\% 54,3$ 'ü, erkeklerin \%58,1'i işiyle ilgili olumlu geri bildirim aldıklarını belirtirken, her iki grubun yaklaşık dörtte biri bu konuda emin olmadıklarını, beşte biri de olumlu geri bildirim almadıklarını belirtmektedir. İşyerindeki başarılarının yazılı veya sözlü olarak takdir edildiğini belirten personel sayısı her iki grupta da üçte birden biraz fazla olup (kadınlar=\%39,1; erkekler=\%36,5), önemli bir kısım bu konuda emin olmadığını ya da takdir edilmediğini vurgulamışlardır. Her iki grubun yaklaşık yarısı işyerinde üstlerin çalışanlar arasında ayrımcılık yaptığını (kadınlar=\%51,1; erkekler=\%55,4) belirtmiş, yine her iki grubun ancak yarıya yakını (Kadınlar $=\% 44,6$, erkekler $=\% 51,4)$ işyerlerinde çalışanlara değer verildiğini düşünmektedirler. İşyerinde arzu edilen ve edilmeyen davranışların açık olarak belirlendiğini belirtenlerin oranı kadınlarda \%43,5, erkeklerde\%45,9 iken, her iki gruptan önemli bir kesimin bu konuda görüş belirtmemesi dikkat çekicidir. Her iki grubun ancak yarısı işyerinde önerilirinin dikkate alındığını, yaptığı işi başkalarına tavsiye edeceğini, amaçların kesin ve belirgin olduğunu belirtirken her iki konuda önemli ölçüde katılımcı ya görüş belirtmemiş ya da olumsuz düşünceye sahiptirler. Katılımcılardan her iki grubun \%40'a yakını ya da biraz fazlası işyeri yönetiminin güvene dayalı, şeffaf ve açık ilişkiler kurulmasını desteklediğini, çalışma ortamlarının eğlenceli olduğunu, işyerinin iyi elemanları işten çıkarmaktan kaçındığını belirtirken, bu görüşler konusunda her iki grubun önemli bir kesimi görüş belirtmemiştir. Genel bir değerlendirme yapmak gerekirse yönetim politika ve uygulamaları kapsamındaki maddelerde olumlu görüşlerin çoğunlukla grubun yaklaşık yarısı tarafindan benimsendiği, yanıt vermeme oranlarının hem kadın hem de erkeklerde oldukça yüksek olduğu dikkat çekmektedir. Buna göre iş yerinde çalışanları objektif değerlendirme, olumlu geri bildirim verme, çalışanların 
yazılı veya sözlü olarak takdir edilmesi konularında yetersizlikler olduğu, personel arasında üstler tarafindan dikkate değer oranda ayrımcılık yapıldığı, çalışanlara yeterince değer verilmediği belirlenmiştir. Ayrıca yönetiminin güvene dayalı, şeffaf ve açık ilişkiler kurulmasını desteklemesi, çalışma ortamlarının eğlenceli olması, iş yerinin iyi elemanları işten çıkarmaktan kaçınması konularında da olumlu ve olumsuz görüşlerin birbirine yakın oranda olması, bu konularda da memnuniyetsizliklerin dikkate değer boyutta olduğunu göstermektedir.

\section{İletişim ve İlişkiler}

İletişim ve ilişkiler kapsamındaki kay kare analizinin gerektirdiği koşulların sağlandığı maddelerde cinsiyete göre yapılan karşılaştırmalarda cinsiyetin etkili bir değişken olmadığı, kadın ve erkek personelin benzer görüşlere sahip oldukları belirlenmiştir. En çok vurgulanan görüşler dikkate alınarak yapılan analize göre her iki grupta da büyük çoğunluk (kadınlar=\%73,9; erkekler=\%82,4) işinde neler yapması gerektiğinden haberdar olduğunu belirtmiştir. Her iki cinsiyette de büyük çoğunluk üstleriyle ilişkilerinin sorunlu olduğunu, çalışma arkadaşlarıyla olan problemleri çözmekte zorlandığını ancak çalışma arkadaşları ile olan ilişkilerinden memnun olduğunu, işini yaparken zorlandığı konularda iş arkadaşlarından yardım alabildiğini belirtmiştir. Katılımcılardan hem kadın hem de erkeklerin büyük çoğunluğu (kadınlar $=\% 71,7$; erkeler=\%75,7) işiyle ilgili zorlandığı konuları üstüne rahatlıkla söylediğini belirtmiştir. Her iki cinsiyetten de katılımcılar kadınlar $=\% 65,2$; erkekler $=\% 70,3$ ) işini yaparken diğer çalışanlarla iletişim kopukluğu yaşadığını belirtmiş ayrıca kadınların dörtte biri (\%25) fikir beyan etmekten kaçınmıştır. Genel bir değerlendirme yapmak gerekirse kadın ve erkek personel işinde neler yapması gerektiğinden haberdar, çalışma arkadaşları ile olan ilişkilerinden memnun, işleriyle ilgili zorlandığı konuları üstüne rahatlıkla söyleyebilmekte ve işini yaparken zorlandığı konularda iş arkadaşlarından yardım alabilmektedir. Buna karşın hem kadın hem de erkek personel çoğunlukla üstleriyle ilişkilerde sorun yaşayabilmekte, çalışma arkadaşlarıyla olan problemleri çözmekte zorlanabilmekte, işini yaparken diğer çalışanlarla iletişim kopukluğu yaşayabilmektedirler.

Araştırmada katılımcıların iş doyumu özellikleri kıdem bağımsız değişkeni dikkate alınarak karşılaştırılmıştır. Elde edilen veriler Tablo 4'te görülmektedir.

Tablo 4. Kıdeme Göre Katılımcıların İş Doyumu Özellikleri

\begin{tabular}{|c|c|c|c|c|c|c|c|}
\hline $\begin{array}{c}\text { Ma } \\
\text { d. } \\
\text { No }\end{array}$ & Kidem & 3 & 2 & 1 & Toplam & $X^{2}$ & $\mathrm{p}$ \\
\hline
\end{tabular}

\section{İşin Yapısı}

\begin{tabular}{|c|c|c|c|c|c|c|c|c|c|c|c|}
\hline \multirow{3}{*}{2} & $1-10$ yll & 14 & 37,8 & 15 & 40,5 & 8 & 21,6 & 37 & 100,0 & \multirow{3}{*}{7,534} & \multirow{3}{*}{0,110} \\
\hline & $11-20$ yil & 32 & 47,8 & 12 & 17,9 & 23 & 34,3 & 67 & 100,0 & & \\
\hline & $21 \mathrm{yll}$ üst & 22 & 35,5 & 18 & 29,0 & 22 & 35,5 & 62 & 100,0 & & \\
\hline \multirow{3}{*}{7} & $1-10$ yıl & 35 & 94,6 & 1 & 2,7 & 1 & 2,7 & 37 & 100,0 & \multirow{3}{*}{$\ldots}$. & \multirow{3}{*}{$\ldots .}$. \\
\hline & $11-20$ yil & 52 & 77,6 & 4 & 6,0 & 11 & 16,4 & 67 & 100,0 & & \\
\hline & 21 yll üst & 48 & 77,4 & 4 & 6,5 & 10 & 16,1 & 62 & 100,0 & & \\
\hline \multirow{2}{*}{12} & $1-10$ y1l & 22 & 59,5 & 9 & 24,3 & 6 & 16,2 & 37 & 100,0 & \multirow{2}{*}{1,374} & \multirow{2}{*}{0,849} \\
\hline & $11-20$ yll & 42 & 62,7 & 16 & 23,9 & 9 & 13,4 & 67 & 100,0 & & \\
\hline
\end{tabular}




\begin{tabular}{|c|c|c|c|c|c|c|c|c|c|c|c|}
\hline & 21 yll üst & 33 & 53,2 & 17 & 27,4 & 12 & 19,4 & 62 & 100,0 & & \multirow{4}{*}{0,585} \\
\hline \multirow{3}{*}{17} & $1-10 \mathrm{y} 1 \mathrm{l}$ & 17 & 45,9 & 7 & 18,9 & 13 & 35,1 & 37 & 100,0 & \multirow{3}{*}{2,842} & \\
\hline & $11-20$ y1l & 37 & 55,2 & 13 & 19,4 & 17 & 25,4 & 67 & 100,0 & & \\
\hline & 21 yll üst & 38 & 61,3 & 11 & 17,7 & 13 & 21,0 & 62 & 100,0 & & \\
\hline \multirow{3}{*}{22} & $1-10 \mathrm{y} 1 \mathrm{l}$ & 13 & 35,1 & 12 & 32,4 & 12 & 32,4 & 37 & 100,0 & \multirow{4}{*}{2,805} & \multirow{4}{*}{0,591} \\
\hline & $11-20$ yll & 17 & 25,4 & 18 & 26,9 & 32 & 47,8 & 67 & 100,0 & & \\
\hline & 21 yll üst & 15 & 24,2 & 19 & 30,6 & 28 & 45,2 & 62 & 100,0 & & \\
\hline \multirow{3}{*}{26} & $1-10$ y1l & 24 & 64,9 & 11 & 29,7 & 2 & 5,4 & 37 & 100,0 & & \\
\hline & $11-20$ y1l & 53 & 79,1 & 9 & 13,4 & 5 & 7,5 & 67 & 100,0 & \multirow[t]{2}{*}{$\ldots .}$. & \multirow[t]{2}{*}{$\ldots \ldots$} \\
\hline & 21 y1l üst & 42 & 67,7 & 16 & 25,8 & 4 & 6,5 & 62 & 100,0 & & \\
\hline \multirow{3}{*}{31} & $1-10$ yıl & 12 & 32,4 & 14 & 37,8 & 11 & 29,7 & 37 & 100,0 & \multirow{3}{*}{3,474} & \multirow{3}{*}{0,482} \\
\hline & $11-20 \mathrm{yll}$ & 28 & 41,8 & 26 & 38,8 & 13 & 19,4 & 67 & 100,0 & & \\
\hline & 21 y1l üst & 19 & 30,6 & 23 & 37,1 & 20 & 32,3 & 62 & 100,0 & & \\
\hline \multirow{3}{*}{34} & $1-10$ yıl & 22 & 59,5 & 13 & 35,1 & 2 & 5,4 & 37 & 100,0 & \multirow{3}{*}{$\ldots .}$. & \multirow{3}{*}{....... } \\
\hline & $11-20$ yil & 47 & 70,1 & 17 & 25,4 & 3 & 4,5 & 67 & 100,0 & & \\
\hline & 21 y1l üst & 31 & 50,0 & 24 & 38,7 & 7 & 11,3 & 62 & 100,0 & & \\
\hline
\end{tabular}

Fiziksel Çalışma Koşulları

\begin{tabular}{|c|c|c|c|c|c|c|c|c|c|c|c|}
\hline & $1-10$ y1l & 29 & 78,4 & 3 & 8,1 & 5 & 13,5 & 37 & 100,0 & & \\
\hline \multirow[t]{3}{*}{1} & $11-20$ yll & 48 & 71,6 & 3 & 4,5 & 16 & 23,9 & 67 & 100,0 & $\ldots$ & $\ldots .$. \\
\hline & 21 y1l üst & 45 & 72,6 & 5 & 8,1 & 12 & 19,4 & 62 & 100,0 & & \\
\hline & $1-10 \mathrm{y} 1 \mathrm{l}$ & 21 & 56,8 & 9 & 24,3 & 7 & 18,9 & 37 & 100,0 & & \\
\hline \multirow[t]{3}{*}{6} & $11-20$ y1l & 44 & 65,7 & 15 & 22,4 & 8 & 11,9 & 67 & 100,0 & 2,993 & 0,559 \\
\hline & 21 yıl üst & 44 & 71,0 & 9 & 14,5 & 9 & 14,5 & 62 & 100,0 & & \\
\hline & $1-10$ yıl & 17 & 45,9 & 8 & 21,6 & 12 & 32,4 & 37 & 100,0 & & \\
\hline \multirow[t]{2}{*}{11} & $11-20$ y1l & 29 & 43,3 & 8 & 11,9 & 30 & 44,8 & 67 & 100,0 & 9,288 & 0,054 \\
\hline & 21 y1l üst & 18 & 29,0 & 6 & 9,7 & 38 & 61,3 & 62 & 100,0 & & \\
\hline
\end{tabular}




\begin{tabular}{|c|c|c|c|c|c|c|c|c|c|c|c|}
\hline \multirow{3}{*}{15} & $1-10 \mathrm{y} 1 \mathrm{l}$ & 23 & 62,2 & 13 & 35,1 & 1 & 2,7 & 37 & 100,0 & \multirow{3}{*}{9,245} & \multirow{3}{*}{0,055} \\
\hline & $11-20 \mathrm{y} 1 \mathrm{l}$ & 51 & 76,1 & 8 & 11,9 & 8 & 11,9 & 67 & 100,0 & & \\
\hline & 21 y1l üst & 43 & 69,4 & 13 & 21,0 & 6 & 9,7 & 62 & 100,0 & & \\
\hline \multirow{3}{*}{20} & $1-10$ y1l & 17 & 45,9 & 9 & 24,3 & 11 & 29,7 & 37 & 100,0 & \multirow{4}{*}{6,200} & \multirow{4}{*}{0,185} \\
\hline & $11-20 \mathrm{y} 1 \mathrm{l}$ & 42 & 62,7 & 16 & 23,9 & 9 & 13,4 & 67 & 100,0 & & \\
\hline & $21 \mathrm{y} 1 \mathrm{lüst}$ & 29 & 46,8 & 20 & 32,3 & 13 & 21,0 & 62 & 100,0 & & \\
\hline \multirow{3}{*}{25} & $1-10$ y1l & 29 & 78,4 & 5 & 13,5 & 3 & 8,1 & 37 & 100,0 & & \\
\hline & $11-20 \mathrm{y} 1 \mathrm{l}$ & 49 & 73,1 & 13 & 19,4 & 5 & 7,5 & 67 & 100,0 & \multirow[t]{2}{*}{$\cdots}$. & \multirow[t]{2}{*}{$\cdots \cdots$} \\
\hline & 21 y1l üst & 38 & 61,3 & 19 & 30,6 & 5 & 8,1 & 62 & 100,0 & & \\
\hline \multirow{3}{*}{30} & $1-10$ yıl & 29 & 78,4 & 6 & 16,2 & 2 & 5,4 & 37 & 100,0 & \multirow{3}{*}{$\ldots}$. & \multirow{3}{*}{$\ldots$} \\
\hline & $11-20 \mathrm{y} 1 \mathrm{l}$ & 47 & 70,1 & 15 & 22,4 & 5 & 7,5 & 67 & 100,0 & & \\
\hline & $21 \mathrm{y} 1 \mathrm{l}$ üst & 54 & 87,1 & 4 & 6,5 & 4 & 6,5 & 62 & 100,0 & & \\
\hline \multicolumn{11}{|c|}{ Yönetim Politika ve Uygulamaları } & \\
\hline \multirow{3}{*}{3} & $1-10$ y1l & 12 & 32,4 & 14 & 37,8 & 11 & 29,7 & 37 & 100,0 & \multirow{3}{*}{12,220} & \multirow{3}{*}{$0,016^{*}$} \\
\hline & $11-20$ yıl & 14 & 20,9 & 31 & 46,3 & 22 & 32,8 & 67 & 100,0 & & \\
\hline & 21 y1l üst & 8 & 12,9 & 19 & 30,6 & 35 & 56,5 & 62 & 100,0 & & \\
\hline \multirow{3}{*}{5} & $1-10$ y1l & 14 & 37,8 & 15 & 40,5 & 8 & 21,6 & 37 & 100,0 & \multirow{3}{*}{10,351} & \multirow{3}{*}{$0,035^{*}$} \\
\hline & $11-20$ yil & 25 & 37,3 & 25 & 37,3 & 17 & 25,4 & 67 & 100,0 & & \\
\hline & $21 \mathrm{y} 1 \mathrm{l}$ üst & 10 & 16,1 & 26 & 41,9 & 26 & 41,9 & 62 & 100,0 & & \\
\hline \multirow{3}{*}{8} & $1-10$ y1l & 26 & 70,3 & 8 & 21,6 & 3 & 8,1 & 37 & 100,0 & \multirow{3}{*}{13,306} & \multirow{3}{*}{$0,010^{*}$} \\
\hline & $11-20$ yil & 43 & 64,2 & 13 & 19,4 & 11 & 16,4 & 67 & 100,0 & & \\
\hline & $21 \mathrm{y} 1 \mathrm{lüst}$ & 24 & 38,7 & 21 & 33,9 & 17 & 27,4 & 62 & 100,0 & & \\
\hline \multirow{3}{*}{10} & $1-10$ y1l & 17 & 45,9 & 15 & 40,5 & 5 & 13,5 & 37 & 100,0 & \multirow{3}{*}{5,263} & \multirow{3}{*}{0,261} \\
\hline & $11-20$ yıl & 25 & 37,3 & 28 & 41,8 & 14 & 20,9 & 67 & 100,0 & & \\
\hline & $21 \mathrm{y} 1 \mathrm{lüst}$ & 21 & 33,9 & 21 & 33,9 & 20 & 32,3 & 62 & 100,0 & & \\
\hline \multirow{2}{*}{13} & $1-10$ y1l & 24 & 64,9 & 10 & 27,0 & 3 & 8,1 & 37 & 100,0 & \multirow{2}{*}{7,956} & \multirow{2}{*}{0,093} \\
\hline & $11-20 \mathrm{y} 1 \mathrm{l}$ & 39 & 58,2 & 18 & 26,9 & 10 & 14,9 & 67 & 100,0 & & \\
\hline
\end{tabular}




\begin{tabular}{|c|c|c|c|c|c|c|c|c|c|c|c|}
\hline & 21 yil üst & 25 & 40,3 & 22 & 35,5 & 15 & 24,2 & 62 & 100,0 & & \\
\hline & $1-10 \mathrm{y} 11$ & 17 & 45,9 & 11 & 29,7 & 9 & 24,3 & 37 & 100,0 & & \\
\hline \multirow[t]{3}{*}{16} & $11-20$ y1l & 34 & 50,7 & 27 & 40,3 & 6 & 9,0 & 67 & 100,0 & 7,804 & 0,099 \\
\hline & 21 yıl üst & 23 & 37,1 & 23 & 37,1 & 16 & 25,8 & 62 & 100,0 & & \\
\hline & $1-10 \mathrm{y} 11$ & 18 & 48,6 & 16 & 43,2 & 3 & 8,1 & 37 & 100,0 & & \\
\hline \multirow[t]{3}{*}{18} & $11-20$ yil & 35 & 52,2 & 27 & 40,3 & 5 & 7,5 & 67 & 100,0 & 14,578 & $0,006^{*}$ \\
\hline & 21 y1l üst & 20 & 32,3 & 24 & 38,7 & 18 & 29,0 & 62 & 100,0 & & \\
\hline & $1-10$ y1l & 17 & 45,9 & 16 & 43,2 & 4 & 10,8 & 37 & 100,0 & & \\
\hline \multirow[t]{3}{*}{21} & $11-20$ yil & 41 & 61,2 & 20 & 29,9 & 6 & 9,0 & 67 & 100,0 & 5,751 & 0,219 \\
\hline & 21 yıl üst & 29 & 46,8 & 21 & 33,9 & 12 & 19,4 & 62 & 100,0 & & \\
\hline & $1-10$ yıl & 26 & 70,3 & 11 & 29,7 & 0 & 0,0 & 37 & 100,0 & & \\
\hline \multirow[t]{3}{*}{23} & $11-20$ yıl & 34 & 50,7 & 26 & 38,8 & 7 & 10,4 & 67 & 100,0 & 13,174 & $0,010^{*}$ \\
\hline & 21 yll üst & 24 & 38,7 & 26 & 41,9 & 12 & 19,4 & 62 & 100,0 & & \\
\hline & $1-10 \mathrm{y} 1 \mathrm{l}$ & 18 & 48,6 & 15 & 40,5 & 4 & 10,8 & 37 & 100,0 & & \\
\hline \multirow[t]{3}{*}{27} & $11-20$ y1l & 42 & 62,7 & 22 & 32,8 & 3 & 4,5 & 67 & 100,0 & 9,039 & 0,060 \\
\hline & 21 yıl üst & 27 & 43,5 & 23 & 37,1 & 12 & 19,4 & 62 & 100,0 & & \\
\hline & $1-10 \mathrm{y} 1 \mathrm{l}$ & 20 & 54,1 & 16 & 43,2 & 1 & 2,7 & 37 & 100,0 & & \\
\hline \multirow[t]{3}{*}{29} & $11-20$ y1l & 36 & 53,7 & 21 & 31,3 & 10 & 14,9 & 67 & 100,0 & 16,589 & $0,002 *$ \\
\hline & 21 yıl üst & 20 & 32,3 & 22 & 35,5 & 20 & 32,3 & 62 & 100,0 & & \\
\hline & $1-10 \mathrm{y} 11$ & 15 & 40,5 & 15 & 40,5 & 7 & 18,9 & 37 & 100,0 & & \\
\hline \multirow[t]{3}{*}{32} & $11-20$ y1l & 28 & 41,8 & 25 & 37,3 & 14 & 20,9 & 67 & 100,0 & 6,326 & 0,176 \\
\hline & 21 y1l üst & 23 & 37,1 & 16 & 25,8 & 23 & 37,1 & 62 & 100,0 & & \\
\hline & $1-10 \mathrm{y} 11$ & 19 & 51,4 & 11 & 29,7 & 7 & 18,9 & 37 & 100,0 & & \\
\hline \multirow[t]{2}{*}{35} & $11-20$ y1l & 37 & 55,2 & 22 & 32,8 & 8 & 11,9 & 67 & 100,0 & 6,605 & 0,158 \\
\hline & 21 y1l üst & 23 & 37,1 & 22 & 35,5 & 17 & 27,4 & 62 & 100,0 & & \\
\hline
\end{tabular}

\section{İletișim ve İlișkiler}




\begin{tabular}{|c|c|c|c|c|c|c|c|c|c|c|c|}
\hline & $1-10 \mathrm{y} 1 \mathrm{l}$ & 29 & 78,4 & 4 & 10,8 & 4 & 10,8 & 37 & 100,0 & & \\
\hline \multirow[t]{3}{*}{4} & $11-20 \mathrm{yll}$ & 51 & 76,1 & 12 & 17,9 & 4 & 6,0 & 67 & 100,0 & $\ldots$ & ..... \\
\hline & 21 y1l üst & 49 & 79,0 & 10 & 16,1 & 3 & 4,8 & 62 & 100,0 & & \\
\hline & $1-10$ y1l & 30 & 81,1 & 6 & 16,2 & 1 & 2,7 & 37 & 100,0 & & \\
\hline \multirow[t]{3}{*}{9} & $11-20 \mathrm{y} 1 \mathrm{l}$ & 62 & 92,5 & 4 & 6,0 & 1 & 1,5 & 67 & 100,0 & $\ldots .$. & $\ldots \ldots$ \\
\hline & 21 yil üst & 52 & 83,9 & 9 & 14,5 & 1 & 1,6 & 62 & 100,0 & & \\
\hline & $1-10 \mathrm{y} 1 \mathrm{l}$ & 29 & 78,4 & 6 & 16,2 & 2 & 5,4 & 37 & 100,0 & & \\
\hline \multirow[t]{3}{*}{14} & $11-20$ y1l & 56 & 83,6 & 8 & 11,9 & 3 & 4,5 & 67 & 100,0 & $\ldots .$. & $\ldots \ldots$ \\
\hline & 21 yıl üst & 45 & 72,6 & 14 & 22,6 & 3 & 4,8 & 62 & 100,0 & & \\
\hline & $1-10$ yil & 27 & 73,0 & 9 & 24,3 & 1 & 2,7 & 37 & 100,0 & & \\
\hline \multirow[t]{3}{*}{19} & $11-20$ yıl & 51 & 76,1 & 12 & 17,9 & 4 & 6,0 & 67 & 100,0 & $\ldots$. & $\ldots \ldots$ \\
\hline & 21 y1l üst & 51 & 82,3 & 7 & 11,3 & 4 & 6,5 & 62 & 100,0 & & \\
\hline & $1-10$ y1l & 30 & 81,1 & 6 & 16,2 & 1 & 2,7 & 37 & 100,0 & & \\
\hline \multirow[t]{3}{*}{24} & $11-20$ y1l & 59 & 88,1 & 6 & 9,0 & 2 & 3,0 & 67 & 100,0 & $\ldots .$. & $\ldots \ldots$ \\
\hline & 21 y1l üst & 51 & 82,3 & 7 & 11,3 & 4 & 6,5 & 2 & 100,0 & & \\
\hline & $1-10$ yil & 30 & 81,1 & 6 & 16,2 & 1 & 2,7 & 37 & 100,0 & & \\
\hline \multirow[t]{3}{*}{28} & $11-20 \mathrm{y} 1 \mathrm{l}$ & 52 & 77,6 & 11 & 16,4 & 4 & 6,0 & 67 & 100,0 & $\ldots .$. & ....... \\
\hline & 21 yil üst & 40 & 64,5 & 15 & 24,2 & 7 & 11,3 & 62 & 100,0 & & \\
\hline & $1-10$ yil & 22 & 59,5 & 12 & 32,4 & 3 & 8,1 & 37 & 100,0 & & \\
\hline \multirow[t]{2}{*}{33} & $11-20$ y1l & 48 & 71,6 & 10 & 14,9 & 9 & 13,4 & 67 & 100,0 & 4,775 & 0,311 \\
\hline & 21 yil üst & 42 & 67,7 & 12 & 19,4 & 8 & 12,9 & 62 & 100,0 & & \\
\hline
\end{tabular}

${ }^{*} \mathrm{p}<0,05$ anlaml $\quad \mathrm{N}=166$

Katılımcıların kıdemleri ile iş doyum düzeyleri arasında anlamlı bir ilişki olup olmadığı kay kare analizi ile test edilmeye çalışılmıştır. Kay kare işleminin kullanım koşullarının sağlandığı maddelerde karşılaştırma yapılabilmiş, koşulların sağlanamadığı 1, 4, 7, 9, 14, 19, 24, 25, 26, 28, 30, 34 Maddeler ise frekans ve yüzdelere dayalı olarak analiz yapılmıştır. Buna göre iş doyumu ölçeğinin boyutlarına göre kıdem değişkenine dayalı olarak elde edilen bulgular ve yorumlar aşağıda ele alınmıştır.

\section{İşin Yapısı}

İşin yapısı kapsamındaki kıdem bağımsız değişkeni açısından 7, 26 ve 34. maddelerde kay kare uygulama koşulları sağlanamadığı için frekans ve yüzdelere göre bulgular ele alınmış, diğer maddelerde yapılan kay kare çözümlemelerinde de kıdemin etkili bir değişken olmadığı, tüm kıdem boyutlarında personelin benzer görüşlere 
sahip oldukları belirlenmiştir. Katılımcıların en yüksek oranda vurgulanan görüşler dikkate alınarak yapılan analize göre kıdem gruplarının büyük ölçüde benzer görüşler sergilediği dikkati çeken bir boyut işlerinde yaratıcıklarını kullanamadıkları boyutu olmuştur (1-10 yıl =\%94,6; 11-20 yıl =\%77,6; 21 yıl ve üstü =\%77,4). $\mathrm{Bu}$ bulguyu bir ölçüde doğrulayıcı bulgulardan biri kıdem gruplarının birbirine yakın görüşlerle vurguladıkları kendi kararlarını alma konusundaki düşünceleridir. Buna göre 11 yıl ve üzerindeki personelin yaklaşık yarısı kendi kararlarını uygulayamadıklarını belirtirken, 1-10 yıl kıdemi olanların ise üçte biri bu görüşü benimsemiştir. $\mathrm{Bu}$ konuda olumlu görüş bildirenler ise 1-10 yıl kıdem grubunda yaklaşı üçte bir iken 11 yıl ve üzerinde kıdemi olanların yaklaşık dörtte biri kendi kararlarını uygulayabildiklerini uygulayabildiğini belirtmektedir. İşlerinin toplum içindeki saygınlığı konusunda da kıdem grupları çoğunlukla olumlu düşünmekle beraber, 1-10 yıl kıdemi olanların üçte birinin, 20 yıl ve üstü kıdemi olanların dörtte birinin bu konuda emin olmadığını belirtmesi dikkat çeken bir bulgudur. Her üç kıdem grubunda da iş ortamı öncelikle monoton olarak değerlendirilmiş, her kıdem grubunun yaklaşık dörtte biri ise bu konuda emin olmadığını, yaklaşık beşte biri ise monoton olmadığını belirtmiştir. Tüm kıdem gruplarındakiler yaptıkları işin öncelikle kişisel gelişimlerine olumsuz etkisi olduğunu $(1-10$ yıl $=\% 59,5 ; 11-20$ yıl $=\% 70,1 ; 21$ yıl ve üstü $=\% 50,0)$ belirtirken bu konuda emin olmadığını belirtenlerin oranları da dikkate değer boyuttadır. Yeteneklerine uygun bir işte çalışma konusunda 21 yıl ve üzeri kıdeme sahip olanlar biraz daha yüksek oranda olmakla beraber $(\% 61,3)$ diğer iki grubunda yarıya yakını da benzer görüş ortaya koymaktadır. Buna karşın 1-10 yıl kıdeme sahip olanların yaklaşık üçte biri, diğer iki kıdem grubunun yaklaşık dörtte biri ise yeteneklerine uygun bir işte çalışmadıklarını düşünmektedirler. Yaptıkları işin çeşitlilik gösterdiğini belirtme oranı ise 11 ve üzeri yıl kıdemi olanların yaklaşık yarısı iken, diğer iki grupta üçte birden biraz fazladır. Personelin 20 yıla kadar kıdemi olanların yaklaşık üçte birinin, 11-20 yıl grubundakilerin ise \%41,8'inin yeterli paraları olsa bu işi bırakabileceklerin ifade etmeleri dikkat çekicidir. Paraları olsa da bırakmayacağını söyleyenlerin oranı da grupların en az dörtte biri düzeyindedir. Genel bir değerlendirme yapmak gerekirse kıdem gruplarının hemen hepsinde personelin yaratıcılığını kullanamadığı, genelde monoton işler yaptıkları, yaptıkları işin kişisel gelişimlerine çok da olumlu bir etkisi olmadığı, genellikle kıdem yükseldikçe yeteneklerine uygun bir işte çalıştıklarını düşünenlerin oranı artığı belirlenmiştir. Bu konuda daha az deneyimi olanların daha kötümser oldukları söylenebilir. Kendi kararlarını uygulayabilme boyutunda sorunlar vardır. Deneyim arttıkça kendi kararlarını uygulama oranının düştüğü gözlenmektedir. Personelin yaptığı işlerde çeşitliliğin genelde sınırlı olduğu söylenebilir. Kıdemlerine göre personelin ciddi bir kesimi ekonomik imkânları iyi olsa bu işi bırakabilme düşüncesindedirler.

\section{Fiziksel Çalışma Koşulları}

Fiziksel çalışma koşulları kapsamındaki kıdem bağımsız değişkeni açısından 1, 25 ve 30. maddelerde kay kare uygulama koşulları sağlanamadığı için frekans ve yüzdelere göre bulgular ele alınmış, diğer maddelerde yapılan kay kare çözümlemelerinde de kıdemin etkili bir değişken olmadığı, tüm kıdem boyutlarında personelin benzer görüşlere sahip oldukları belirlenmiştir. Katılımcıların en yüksek oranda vurgulanan görüşler dikkate alınarak yapılan analize göre kıdem gruplarının büyük ölçüde benzer görüşler sergilediği dikkati çeken bir boyut işyerindeki aydınlanma koşulları boyutu olmuştur $(1-10$ yıl $=\% 78,4 ; 11-20$ yıl $=\% 70,1 ; 21$ yıl ve üstü $=\% 87,1)$. Kıdem gruplarının birbirine yakın görüşlerle vurguladıkları maddelerden biri de işyerinde temizlik kurallarına dikkat edilmesidir (1-10 yıl $=\% 78,4 ; 11-20$ yıl $=\% 73,1 ; 21$ yıl ve üstü $=\% 61,3)$. İşyerinin, iş için ihtiyaç olan malzemeleri en kısa sürece temin edip etmemesi konusunda kıdem gruplarından 11-20 yıl kıdemi olanların beşte üçü, 1-10 yıl kıdemi olanların yarıya yakını ve 21 yıl ve üzeri kıdemi olanların da yarıya yakını malzemelerin en kısa sürede temin edildiği yönünde görüş bildirmiştir. Her üç kıdem grubundan da yaklaşık dörtte birlik bir grubun emin olmadığını belirtmesi dikkate çeken bir bulgudur. Tüm kıdem gruplarındakiler işyerlerinde rahatsız edici düzeyde gürültü olduğunu (1-10 yıl =\%62,2; 11-20 yıl =\%76,1;21 yıl ve üstü =\%69,4) belirtirken bu konuda emin olmadığını belirtenlerin oranları da dikkate değer boyuttadır. İşyerinde yaptı̆̆ iş karşılı̆̆ ücreti tatmin edici bulma ile ilgili 21 yıl ve üzeri kıdeme sahip olanlar ücretin tatmin edici olmadığını $(\% 61,3)$ belirtirken diğer iki grubunda yarıya yakını tatmin edici bulmaktadır. İşyerinde alınmış güvenlik tedbirlerini yeterli bulma konusunda tüm kıdem grupları yeterli olduğu yönünde görüş belirtmiştir $(1-10$ yıl = \%56,8; 11-20 yıl $=\% 65,7 ; 21$ yıl ve üstü $=\% 71,0)$. 1-10 yıl ve 11-20 yıl kıdeme sahip olan çalışanların beşte birinin emin olmadığını belirtmesi ise dikkate değer bir bulgudur. Tüm kıdem grubundaki çalışanların çoğunluğu işyeri tarafından sağlanan yemek olanaklarını tatmin edici bulmaktadır $(1-10$ yıl $=\%$ 78,4; 11-20 yıl = \% 71,6; 21 yıl ve üstü =\%72,6). 11-20 yıl kıdeme sahip çalışanların beşte biri ise yemek olanaklarını tatmin edici bulmamaktadır.

\section{Yönetim Politika ve Uygulamaları}


Yönetim politika ve uygulamaları kapsamındaki kıdeme göre yapılan kay kare analizlerine göre 3-5-8-18-2329. maddelere ilişkin görüşlerde kıdemin önemli bir değişken olduğu, farklı kıdem dönemlerine göre personelin görüşlerinin değiştiği belirlenmiştir. Buna göre 21 yıl ve üzeri kıdeme sahip olanların yarıdan fazlası terfi sisteminin yeterince açık olmadığını belirtirken, 11-20 yıl kıdemi olanların çoğunluğu $(\% 46,3)$ emin olmadıklarını belirtmektedirler. Bu konuda olumlu görüş belirtenler incelendiğinde 1-10 yıl kıdemi olanların üçte birinin terfi sisteminin açık ve adaletli olduğu düşüncesinde olduğu belirlenmiştir. İşyerinde çalışanların objektif değerlendirilmesi konusunda kıdemi yüksek olan personelin daha olumsuz düşündügü̆, işyerindeki geribildirimlerin yapıcı olduğu görüşüne daha az kıdemi olanların daha yüksek oranda katıldıkları (1-10 $\mathrm{y} 1 \mathrm{l}=\% 70,3 ; 11-20 \mathrm{yll}=\% 64,2)$, yönetimin işyerinde güvene dayalı açık ve şeffaf ilişkiler kurulmasını desteklediği yönündeki görüşe de yine kıdemi az olanların yaklaşık yarısının daha olumlu görüş bildirdikleri gözlenmiştir. $\mathrm{Bu}$ konuda her üç kıdem grubunun \%40 dolayında bir kesiminin emin olmadığını belirtmesi dikkat çekicidir. İşle ilgili önerilerin dikkate alınması konusunda ise en olumlu görüşü 0-10 yıl kıdem grubu \%70,3 ile ilk sırada benimserken, 11-20 yıl kıdem grubunun yarısı da bu görüşe katılmaktadır. Buna karşın 21 yıl ve üzeri kıdem grubu bu konuda öncelikle emin olmadıklarını belirtmişlerdir. İyi elemanların işten çıkarılmasında kaçınıldığı görüşü ise 1-20 arası kıdem grubundakilerin yaklaşık yarısı tarafindan benimsenmiştir. Her üç kıdem grubunun bu konuda emin olmayanların oranı dikkate değer orandadır.

Yukarıda belirtilen maddeler dışında diğer maddelerde yapılan kay kare çözümlemelerinde de kıdemin etkili bir değişken olmadığı, tüm kıdem boyutlarında personelin benzer görüşlere sahip oldukları belirlenmiştir. Buna göre işyerinde başarıların yazılı ve sözlü olarak değerlendirilme konusunda 0-10 yıl kıdeme sahip olanların yarıya yakını olumlu düşünürken, diğer kıdem gruplarının yaklaşık üçte biri bu görüşe katılmaktadır. Katılımcıların önemli bir kısmının bu konuda emin olmadıkların belirtmeleri ise dikkate değerdir. Üstlerin çalışanlar arasında ayırım yapıldığı görüşünü en çok 1-10 yıl kıdeme sahip olanlar benimsemişler $(\% 64,9), 11-20$ yıl kıdeme sahip olanların da yarıdan fazlası da $(\% 58,2)$ benzer görüşe sahiptir. İşyerinde arzu edilen ve edilmeyen davranışların açıça belirlenmesi konusunda ise olumlu görüşlerin ilk başında \%50,7 ile 11-20 yıl kıdem grubu gelirken, bunu yakın bir oranla $(\% 45,9)$ 1-10 yıl kıdeme sahip grup yer almaktadır. Bu açıdan her üç kıdem grubunun önemli bir kesimi emin olmadıklarını belirtmektedirler. Kurumda çalışmayı başkalarına tavsiye etme ve işyerindeki amaçların yeterince açık olması konusunda 11-20 yıl kıdemi olanların üçte ikisi olumlu görüş belirtmiş diğer kıdem grupların yarıya yakını bu düşünceleri benimsemişlerdir. Her üç kıdem grubunun yaklaşık \%30 ila \%43'lük kesimi ise bu konuda emin olmadıklarını belirtmişlerdir. İşyerini eğlenceli bir ortam olarak değerlendirenlerle bu konuda emin olmayanların 1-20 yıl kıdem gruplarında beşte iki oranı ile dengeli dağıldıkları belirlenirken, 21 yıl ve üzeri kıdeme sahip olanların buna yakın bir oranda eğlenceli bulmadıkları gözlenmiştir. İşyerinde çalışanlara değer verilmesi konusunda ise 1-20 yıl kıdem grubundakilerin yarıdan biraz fazlası olumlu düşünürken, 21 yıl ve üzerindekiler \%37,1 oranında bu görüşe katılmışlardır.

Elde edilen bulgulara göre kıdem arttıkça terfi sistemini adaletli ve açık bulma oranı ve personelin objektif değerlendirildiği oranı da düşmektedir. Geri bildirimin yapıcı olması daha az kıdeme sahip personel tarafindan daha fazla olumlu bulunmuştur. İlişkilerin güvene dayalı açık şeffaf olması 1-20 yıl kıdemlilerin yarısı tarafindan olumlu bulunmuş, iş ile ilgili önerilerin dikkate alınması konusunda 1-10 yıl kıdeme sahip olanlar daha olumlu, başarının yazılı ve sözlü değerlendirilmesi konusunda kıdem durumuna göre olumlu görüşler ve bu konuda emin olmama görüşleri dengeli dağılmaktadır. Daha az kıdeme sahip olanların çalışanlar arasında ayırım yapıldığını düşündükleri görülmüştür. Yaptıkları işi başkalarına tavsiye etme ve amaçların açıklığı konusunda kıdem gruplarına göre olumlu görüş bildirenlerin oranı biraz daha fazla olmakla birlikte emin olmayanların da azımsanmayacak oranda olduğu ortaya çıkmıştır. İşyerini eğlenceli bulanlarla bu konuda emin olmadıklarını belirtenler birbirine yakın oranlardadır. Çalışanların 1-20 yıl kıdem düzeyine sahip olanların yaklaşık yarısı çalışanlara değer verildiğini düşünmektedirler. Her üç kesimin ortalama üçte birinin bu konuda emin olmadıkları da belirlenmiştir.

\section{İletişim ve İlişkiler}

İletişim ve ilişkiler kapsamındaki kıdem bağımsız değişkeni açısından 4, 9, 14, 19, 21 ve 28. maddelerde kay kare uygulama koşulları sağlanamadığı için frekans ve yüzdelere göre bulgular ele alınmış, 33. madde de yapılan kay kare çözümlemelerinde de kıdemin etkili bir değişken olmadığı, tüm kıdem boyutlarında personelin benzer görüşlere sahip oldukları belirlenmiştir. Katılımcıların en yüksek oranda vurguladıkları görüşler dikkate alınarak yapılan analize göre kıdem gruplarının büyük ölçüde benzer ve olumlu görüşler sergilediği boyutlardan biri işlerinde neler yapmaları gerektiğinden haberdar oldukları yönündedir $(1-10$ yıl $=\% 78,4 ; 11-20$ yıl $=\% 76,1 ; 21$ yıl ve üstü $=\% 79,0)$. Tüm küm kıdem grupları üstleri ile olan ilişkilerinde sorunlar yaşadıklarını $(1-10$ yıl $=$ 
$\% 81,1 ; 11-20$ yıl $=\% 92,5 ; 21$ yıl ve üstü =\%83,9) belirtmişlerdir. Tüm kıdem gruplarının benzer ve büyük çoğunlukla olumlu görüş bildirdikleri boyutlardan biri de çalışma arkadaşları ile ilişkilerinden memnuniyet durumları olmuştur (1-10 yıl $=\% 78,4 ; 11-20$ yıl $=\% 83,6 ; 21$ yıl ve üstü $=\% 72,6)$. Buna karşın çalışma arkadaşları ile sorun yaşadıklarında ise çoğunlukla sorunu çözmekte zorlandıkları da ortaya çıkmıştır 1-10 yıl kıdeme sahip personelin \%24,3'ünün fikir beyan etmemesi ise dikkate değerdir. Çalışanların tüm kıdemlerde 5 de 4'ü iş arkadaşlarından işle ilgili zorlandığı konularda yardım alabileceğini belirtmiştir İşi ile ilgili zorlandığı konuları üstüne rahatlıkla söyleme konusunda 1-10 yıl kıdeme sahip olanların 5'te 4'ü (\%81,1), 11-20 yıl kıdeme sahip olanların \%77,6'sı ve 21 yıl ve üzeri kıdeme sahip olanların \%64,5'i olumlu görüşe sahiptirler. 21 yıl ve üzeri kıdeme sahip çalışanların yaklaşık 4'te 1'i $(\% 24,2)$ emin olmadıklarını belirtmiştir. İşlerini yaparken diğer çalışanlarla iletişim kopukluğu yaşadıklarını belirtenlerin oranları ise 1-10 yıl kıdeme sahip çalışanların \% $\% 59,5$ 'i, 11-20 yıl kıdeme sahip çalışanların \%71,6'sı ve 21 yıl ve üstü kıdeme sahip olanların \%67,7'sidir. 1-10 yıl kıdeme sahip çalışanların azımsanmayacak oranda bir bölümü $(\% 32,4)$ emin değilim diyerek fikir beyan etmemiştir.

Buna göre çalışanların kıdemlerinin iletişim ve ilişkiler konusunda etkili bir değişken olmadığı belirlenmiş, tüm kıdem grupları benzer görüşler ortaya koymuşlardır. Genel bir değerlendirme yapmak gerekirse çalışanlar kıdemlerine bağlı olmaksızın çoğunlukla işlerinde neler yapmaları gerektiğini bilmekte, çalışma arkadaşları ile ilişkilerinden memnundurlar. Ancak arkadaşları ile bir sorun yaşarlarsa çoğunlukla çözüm boyutunda sorunlar yaşamakta, aynı zamanda üstleri ile de sorunlar yaşayabilmektedirler. Yine kıdem değişkeninin önemli bir değişken olmadığı diğer bulgularda da çalışanların çoğunlukla işleri ile ilgili yardım alabilecekleri, zorlandıkları konuları üstlerine söyleyebilecekleri, işlerini yaparken iletişim sorunları da yaşabildikleri ortaya çıkmıştır.

\section{Tartışma ve Sonuç}

Araştırma sonucunda elde edilecek bulgulara göre MEB’e bağlı bir genel müdürlükte görevli personel hakkında şunlar söylenebilir:

İşin Yapısı boyutunda çoğunlukla işlerinde yaratıcılıklarını kullanabilme ve yeteneklerine uygun işte çalışma ve işlerinin toplumdaki yerinin saygınlığı konusunda olumlu düşünmektedirler. Araştırmaya katılan MEB personelinin üçte birlik kesimin işlerinin saygınlığı ve yeteneklerine uygun işte çalışma konusunda yeterince olumlu düşünmedikleri ortaya çıkmıştır. Bunun yanısıra çalışanlar çoğunlukla kendi başlarına karar alıp uygulayamamakta, işlerini monoton bulmaktadır. Karaköse ve Kocabaş’ın (2006) özel ve devlet okullarında görev yapan öğretmenlerin iş doyumu ile igili yaptıkları araştırmada devlet okulunda görev yapan öğretmenler bulundukları kurumda görev yapmanın kendilerine önemli bir itibar kazandırmadığını belirtmiş olmalarının benzer bir sonuç olduğu söylenebilir. Sonuç olarak kamu kurumlarında görev yapanlardan azımsanmayacak oranda iş doyumu düşük personel olduğu sonucu Erdoğan (2017) tarafindan yapılan araştırma bulgularıyla da örtüşmektedir.

Fiziksel çalışma koşulları açısından çalışanlar işyerinde yemek, güvenlik önlemleri, temizlik, 1şıklandırma vb. durumlar genelde olumlu düşünürken, gürültü açısından ise olumsuz bir ortam olduğu düşünmektedirler. Ayrıca verilen ücretlerde genel olarak yetersiz bulunmaktadır.

Yönetim politika ve uygulamaları açısından çalışanlar çoğunlukla işlerine dönük yapıcı geribildirim almakta, kurumda çalışmayı arkadaşlarına tavsiye etmekte, çalışanların işle ilgili önerileri dikkate alınmaktadır. Ancak pek çok maddede yanıt vermekten kaçınan katılımcı oranlarının da dikkat çekmektedir. Bunun yanısıra çoğunlukla açık ve adaletli bir terfi sistemi olmadığı, çalışanların değerlendirilmesinde objektif davranılmadığı, üstlerin çalışanlar arası ayrımcılık yaptığı, çalışanların çalışma ortamını eğlenceli bulmadığı söylenebilir. Araştırma bulgularının aksini gösteren başka bir araştırma ise şöyledir: Karaköse ve Kocabaş'ın (2006) özel ve devlet okullarında görev yapan öğretmenlerin iş doyumu ile igili yaptıkları araştırmada yöneticilerin karar verirken çalışanların görüşlerinden yararlanması konusunda özel ve devlet okullarında farklılık olduğunu ortaya koymuşlar ve devlet okullarında yöneticilerin isle ilgili kararları verirken çalışanların görüşlerine yer vermediğini belirtilmişler ayrıca devlet okullarında çalısan ögretmenler yöneticilerinin olumlu davranısların pekistirilmesine daha az önem verdiklerini belirtmislerdir.

İletişim ve ilişkiler bağlamında ise çalışanlar çoğunlukla işlerinde ne yapmaları gerektiğinden haberdardırlar. Ayrıca çalışma arkadaşlarıyla ilişkilerinden memnun, zorlandığı konularda iş arkadaşlarından 
yardım isteyebilmekte ve üstlerine işle ilgili zorlandıkları konuları rahatlıkla söyleyebilmektedir. Ancak genel olarak katılımcıların üstleri ile ilişkilerinde sorunlar yaşayabildikleri ortaya çıkmıştır. Çalışanların iş doyumlarında üstleri ile olan ilişkilerin önemli bir değişken olduğu (Özsüer, 2016) dikkate alınırsa yaşanan sorunların çalışanların iş doyumunu olumsuz etkileyebileceği bir gerçektir. Araştırmada personelin çalışma arkadaşları ile sorun yaşadıklarında bunları çözmekte sorun yaşayabildikleri ve iş yaparken diğer çalışanlarla iletişim kopukluğu yaşayabildikleri de ortaya çıkmıştır. Karaköse ve Kocabaş'ın (2006) özel ve devlet okullarında görev yapan öğretmenlerin iş doyumu ile igili yaptıkları araştırmada da benzer sonuçlar elde edilmiş ve hem özel hem de devlet okulunda çalışanlar iş arkadaşları ile ilişkilerinin iyi olduğunu belirtmiştir. Bu sonuç Eryılmaz (1987), tarafından yapılan araştırmanın sonuçlarıyla benzerlik göstermektedir. Eryılmaz (1987), yaptığı araştırmada örgütsel iletişimin çalışanların motivasyonu açısından son derece önemli olduğu sonucuna ulaşmıştır.

Cinsiyet açısından yapılan karşılaştırmalarda işin yapısı, yönetim politika uygulamaları, iletişim ve ilişkiler boyutlarında anlamlı bir farklılık belirlenmemiştir. Sağır'ın (2016) MEB Hayat Boyu Öğrenme Genel Müdürlüğü çalışanlarının katılımı ile yaptığı araştırmada da çalışanların cinsiyetlerinin iş doyumu açısından önemli bir değişken olmadığı sonucuna ulaşılmıştır. Kılıç (2011), Avşaroğlu ve Deniz (2005), Tüzemen (2004), Ayan, Kocacık ve Karakuş (2009) ve Çekiç (2017) tarafindan yapılan araştırmalarda da cinsiyete göre iş doyumu açısından anlamlı farklılık belirlenmemiş olması da araştırma bulgusu ile benzerlik göstermektedir. Ancak fiziksel çalışma koşullarından sadece işyerinde rahatsız edici oranda gürültü olması konusu ile cinsiyet arasında anlamlı bir ilişki olduğu belirlenmiştir Genel olarak her iki grup ta işyerindeki gürültüden şikâyetçi olmakla beraber, erkeklerin üçte birinin görüş bildirmemiş olması gürültüyü önemsememe ya da farkında olmama olarak da açıklanabilir.

Kıdem değişkenine göre yapılan karşılaştırmalarda işin yapısı açısından anlamlı bir ilişki belirlenmemiştir. Kıdem gruplarının hemen hepsinde personelin yaratıcılığını kullanamadığı, genelde monoton işler yaptıkları, yaptıkları işin kişisel gelişimlerine çok da olumlu bir etkisi olmadığı belirlenmiştir. Bu konuda daha az deneyimi olanların daha kötümser oldukları ortaya çıkmıştır. Kıdemlerine göre personelin ciddi bir kesimi ekonomik imkânları iyi olsa bu işi bırakabilme düşüncesindedirler. Nitekim Sağır'ın yaptığı araştırmada da (2016) iş doyumunda ücret önemli bir değişkendir. Buna göre personelin aldığı ücretten yeterince memnun olmadığı söylenebilir.

Fiziksel çalışma koşulları kapsamındaki kıdem bağımsız değişkeni açısından kıdemin etkili bir değişken olmadığı, tüm kıdem boyutlarında personelin benzer görüşlere sahip oldukları belirlenmiştir. Buna göre kıdem gruplarının büyük çoğunluğu iş yerinin aydınlanma, temizlik koşullarını olumlu değerlendirmektedir. Kıdem grupları çoğunlukla işyerlerinde rahatsız edici düzeyde gürültü olduğunu, güvenlik önlemlerini ve yemek olanaklarını yeterli görmektedirler. Ücret konusunda ise kıdemi daha fazla olanlar ücreti daha yetersiz bulma eğilimindedirler.

Yönetim ve politika uygulamaları açısından kıdeme göre bulgular incelendiğinde kıdem arttıkça terfi sistemini adaletli ve açık bulma oranı ve personelin objektif değerlendirildiği oranı da azalmakta olduğu dikkate alınırsa, bu açılardan kıdem arttıkça iş doyumunun azaldığı söylenebilir Nitekim Acar'ın öğretmenler üzerinde yaptığı araştırmada da (2016) kıdem arttıkça iş doyumu düşebilmektedir. İşyerindeki ilişkilerin güvene dayalı açık şeffaf olması 1-20 yıl kıdemlilerin yarısı tarafından olumlu bulunmuştur. İş ile ilgili önerilerin dikkate alınması konusunda 1-10 yıl kıdeme sahip olanlar daha olumlu görüşleri varken, çalışanlar arasında ayırım yapıldığını düşünmeleri de dikkate değer bir bulgudur. İşyerini eğlenceli bulanlarla bu konuda emin olmadıklarını belirtenler birbirine yakın oranlardadır. Çalışanların 1-20 yıl kıdem düzeyine sahip olanların yaklaşık yarısı çalışanlara değer verildiğini düşünmektedirler. Her üç kesimin ortalama üçte birinin bu konuda emin olmadıkları da belirlenmiştir.

Çalışanlar kıdemlerine bağlı olmaksızın çoğunlukla işlerinde neler yapmaları gerektiğini bilmekte, çalışma arkadaşları ile ilişkilerinden memnundurlar. Ancak arkadaşları ile bir sorun yaşadıklarında çoğunlukla çözme konusunda sorun yaşanmakta, aynı zamanda üstleri ile de sorunlar yaşayabilmektedirler. Yine kıdem değişkeninin önemli bir değişken olmadığı diğer bulgularda da çalışanların çoğunlukla işleri ile ilgili yardım alabilecekleri, zorlandıkları konuları üstlerine söyleyebildikleri belirlenmiştir ve işlerini yaparken iletişim sorunları yaşayabilmektedirler.

\section{Öneriler}


Araştırma bulgularına dayalı olarak aşağıdaki öneriler dile getirilebilir:

1. Çalışanlar işlerini monoton bulmaktadır. Bu monotonluğun önlenmesi için alanda profesyonelleşme gerektirmeyen rutin işlerin yapımında, çalışanların işler arası bir rotasyon düzeninde çalışmaları bu monotonluğu azaltmaya yardımcı olabilir.

2. Çalışanlar arası iş arkadaşlığını güçlendirme amaçlı düzenlenecek, tüm çalışanların hatta belki ailelerinin de katılacakları sosyal aktivitelerin (sinema, konser, şiir dinletisi v.b.) düzenlenmesi işin motonluğunu azaltmaya yardımcı olabilir.

3. Ergonomik oturma koltukları, bilgisayar masaları, el bileğini destekleyici mouse pad'ler, koltuklara ortopedik sırt destekleri gibi fiziki yorgunluğu azaltıcı önlemler almak da çalışanların işlerine bağlılığını, yorgunluktan kaynaklı işini monoton bulmayı engelleyebilir.

4. Çalışanlara belirli saatlerde kütüphane zamanı tanınabilir ve planlı bir şekilde başka kurum ziyaretleri gerçekleştirmeleri sağlanabilir.

5. Çalışanlar kendi başlarına karar alıp uygulama konusunda rahatsızlıklarını dile getirmişlerdir. Çalışanların kararlarda söz sahibi olması ve bu kararların özellikle işyeri ve işleyiş ile ilgili kendilerini de etkileyen kararlar olması çalışanların kendini daha değerli ve işyerine ait hissetmesine yardımcı olacaktır.

6. Çalışanlar, yaptıkları işin yeteneklerine uygunluğu ve toplumdaki saygınlığı konusunda genelde olumlu düşüncelere sahip değildir. Bu olumsuzluğu gidermek adına, çalışanların mevcut beceri, yetenek ve bilgilerine uygun birimlerde değerlendirilmesi, gerekli özelliklere sahip olmayanların veya kendini geliştirmek isteyenlerin seminer, kurs ve eğitim yoluyla yetersizlikleri aşmalarının ve kendilerini geliştirmelerinin sağlanması da iş doyumuna ve işyerindeki kaliteye olumlu katkı sağlayacaktır.

7. Çalışanlar işyerlerinde rahatsız edici düzeyde gürültü olduğunu belirtmişlerdir. Farklı işler yapıp aynı odayı paylaşmak durumunda kalan veya oda yetersizliği nedeniyle ortak oda kullanmak durumunda kalan çalışanlar için uygun çalışma koşullarının sağlanması gerekmektedir. Kurum olarak değerlendirilecek binalarda yerleşme öncesi planlama yapılmalı, birimler, iş yükleri, kişi sayısı gibi durumlar değerlendirilerek ona göre yerleşim planları yapılmalıdır.

8. Çalışanlar ücretlerini yetersiz bulmaktadır. Tüm çalışanların ücretlerinde iyileştirme yapılması veya belirli bir başarı veya gayret üzerinde çalışanlara ek ücret prim gibi teşvik edici katkıların sağlanması hem işi monotonluktan çıkaracak hem çalışanları başarılı olma ve yüksek performansla çalışmaya teşvik edecektir.

9. Çalışanlar genellikle üstlerinin çalışanlar arası ayrımcılık yaptığını ifade etmişlerdir. Çalışanların değerlendirilmesi, terfi gibi durumlarda objektif ve herkes tarafından görülebilir değerlendirmelerin yapılması yararlı olacaktır.

10. Çalışanlar çoğunlukla iş ortamlarını eğlenceli bulmadıklarını vurgulamışlardır. Çalışanların yaptıkları işle ilgili benzer kurumlardan uzmanlarla görüşme veya birlikte çalışmalarına önayak olunması, onurlandırılması, çalışma saati dışında kurum korosu, tiyatro grubu kurulması gibi düzenlemeler işin ve iş ortamının eğlenceli bulunmasına yardımcı olacaktır. İşte doyumu sağlayabilmek için kurumların; işi daha ilginç, ilgi çekici, kişisel ödüllendirmelerin olduğu motivasyonu destekleyen etkenlere odaklanmaları gerekmektedir.

11. Çalışanlardan bir bölümü üstleri ile iletişimde problem yaşadıklarını belirtmişlerdir. Yönetimde yer alanların ve tüm çalışanların, etkili iletişim, empati, toplumsal değerler, drama gibi konularda eğitimlerden almaları iş doyumuna olumlu yansıyacaktır.

12. Çalışanların dikkate değer bir bölümü iş arkadaşları ile çalışma ortamlarında iletişim kopukluğu yaşadıklarını belirtmiştir. Çalışanların iş yerlerindeki iş tanımları, yetkileri ve sorumluluklar çok net bir biçimde belirlenmelidir.

13. Araştırma sorularının çoğunda neredeyse üçde birlik bir kesim çalışan sorulara yanıt vermekten kaçınmıştır. $\mathrm{Bu}$ durum bir fikri olmamaktan çok yanıt vermekten çekinmek olarak da yorumlanabilir. Çalışanların kendilerini ifade etme konusunda güven duyabilecekleri bir ortamın sağlanması gereklidir.

14. Araştırmacı tarafindan ölçeklerin uygulanması sırasında çalışanlar üzerinde genel bir mutsuzluk, çekinme, bıkkınlık gözlenmiştir. 1880 yılında Fransız nörolog Jules Cotard'a başvuran 43 yaşındaki bir kadın, 
beynini, sinir hücrelerini, midesini hissetmediğini hatta kendisinin de ölü olduğunu söylemiştir. Bu düşünceleri nedeniyle yemek yemeye ihtiyacı olmadığı kanısında olan kadın açlıktan ölmüştür. Benzer vaka ile 1788 yılında Fransız doğabilimci ve felsefe yazarı Charles Bonnet karşılaşmıştır (Ak, 2016). Boynuna aldığı darbe sonucu bir tarafi felç olan bir kadından haberdar olan Bonnet, konuşma yeteneğini sonradan tekrar kazandığında kadının öldüğüne inandığını anlamıştır. Literatüre Cotard sendromu ya da yürüyen ceset sendromu olarak geçen bu durum çalışanların bir kısmının araştırma sorularına yanıt vermekten, fikir beyan etmekten kaçınmasına, işindeki monotonluk, bıkkınlığına dolaylı yoldan bir açıklama olarak da görülebilir. 


\section{References}

Acar, F. M. (2016). Okul öncesi öğretmenlerinin tükenmişlik ve iş doyumu düzeylerinin bazı değişkenler açısından incelenmesi [Examination of burnout and job satisfaction levels of pre-school teachers in terms of some variables]. Çağ Üniversitesi, Sosyal Bilimler Enstitüsü: Mersin: Yayınlanmamış Yüksek Lisans Tezi.

Ak, Ö. (2016). Cotard Sendromu- Var mıyım? Yok muyum?[Cotard Syndrome-Do i exist or not?]. Tübitak Bilim ve Teknik Dergisi, Aralık 2016, Sayı, 589.

Akat, İ. (1984). İşletme Yönetimi [Business Administration]. İzmir: Üçel Yayıncılık.

Ayan, S., Kocacık, F., Karakuş, H. (2009). Lise öğretmenlerinin iş doyumu düzeyi ile bunu etkileyen bireysel ve kurumsal etkenler: Sivas merkez ilçe örneği [The level of job satisfaction of high school teachers and the individual and institutional factors affecting it: Sivas central district sample]. Anadolu Psikiyatri Dergisi, 10, $18-25$.

Avşaroğlu, S., Deniz, M.E. (2005). Teknik öğretmenlerde yaşam doyumu iş doyumu ve mesleki tükenmişlik düzeylerinin incelenmesi [Examining life satisfaction job and professional burnout levels in technical teachers]. Selçuk Üniversitesi Sosyal Bilimler Enstitüsü Dergisi, Sayı:14.

Barutçu, E. ve Serinkan, C. (2008). Günümüzün Önemli Sorunlarından Biri Olarak Tükenmişlik Sendromu ve Denizli'de Yapılan Bir Araştırma [Burnout Syndrome as One of the Important Questions of Today and a Research in Denizli]. Ege Akademik Bakış Dergisi, 8(2), 541-561.

Bilgin, N. (2003). Sosyal Psikoloji Sözlügü: Kavramlar, Yaklaşımlar [The Dictionary of Social Psychology: Concepts, Approaches], 1.Baskı, İstanbul: Bağlam Yayınları.

Bogler, R. (2002). Two profiles of school teachers: a discriminant analysis of job satisfaction. Teaching and Teacher Education, 18(6), 665-673.

Brouwers, A., Will, J. G., Evers, W. J. G. \& Tomic, W. (2001). Self-efficacy in eliciting social support and burnout among secondary-school teachers. Journal of Applied Social Psychology, 31(7), 1474-1491.

Büyüköztürk, Ş., Çakmak, E. K., Akgün, Ö, E., Karadeniz, Ş. ve. Demirel, F. (2014). Bilimsel Araştırma Yöntemleri [Scientific Research Methods]. 17. Baskı. Ankara: Pegem A Akademi Yayınc1lı.

Çekiç, O. (2017). Okul yöneticilerinin duygusal emek ve iş doyumu arasındaki ilişkiye dair bir inceleme [A review of the relationship between school managers' emotional labor and job satisfaction]. Çanakkale Onsekiz Mart Üniversitesi, Eğitim Bilimleri Enstitüsü: Yayınlanmamış Yüksek Lisans tezi.

Çetinkanat, C. (2000). Örgütlerde Güdülenme ve Işsdoyumu [Motivation and Job Satisfaction in Organizations]. Ankara: Anı Yayıncılık.

Düren, A. Z. (2000). 2000’li Yıllarda Yönetim [Management over 2000 years]. İstanbul: Alfa Basım Yayım Dagitim.

Employee Job Satisfaction And Engagement Revitalizing a Changing Workforce, Retrieved 25.11.2017, from https://www.shrm.org/hr-today/trends-and-forecasting/research-and-surveys/Documents/2016-Employee-Job Satisfaction-and-Engagement-Report.pdf

Erdem, A. R. (1998). Süreç Kuramlarının Eğitim Yönetimine Katkıları. Pamukkale Üniversitesi Eğitim Bilimleri Dergisi, 4(4), 51-57.

Erdoğan, H. (2017). Ortaokul yöneticilerinin öğretim liderliği ile ögretmenlerin iş doyumu arasındaki ilişkinin incelenmesi [Examining the relationship between the teaching leadership of secondary school administrators and job satisfaction of teachers]. İstanbul Sabahattin Zaim Üniversitesi Sosyal Bilimler Enstitüsü. İstanbul: Yayınlanmamış Yüksek Lisans Tezi.

Eren, E. (2008). Örgütsel Davranış ve Yönetim Psikolojisi [Organizational Behavior and Management Psychology], 11. Bask1, İstanbul: Beta Yayınları. 
Ergin, C. (1992). Doktor ve Hemşirelerde Tükenmişlik ve Maslach Tükenmişlik Ölçeğinin Uyarlanması [Adaptation of Burnout and Maslach Burnout Scale in Doctors and Nurses]. 143-154, içinde: Bayraktar, R. ve Dă̆, İ., VII. Ulusal Psikoloji Kongresi Bilimsel Çalışmaları, Türk Psikologlar Derneği Yayını, Ankara.

Ertürk, E., Keçecioğlu, T. (2012). Çalışanların iş doyumları ile mesleki tükenmişlik düzeyleri arasındaki ilişkiler: öğretmenler üzerine örnek bir uygulama [Relations between job satisfaction and vocational burnout levels of employees: a sample application on teachers]. Ege Akademik Bakış Dergisi, 12(1), 41-54.

Eryılmaz, M. K. (1987). Iletişim Kanalları ve Motivasyon [Communication Channels and Motivation]. Yayınlanmamış yüksek lisans tezi, Ege Üniversitesi Sosyal Bilimler Enstitüsü, İzmir: Türkiye.

Judge, T. A. , Parker, S., Colbert, A. E. , Heler, D. ve Ilıes R. (2001). Job Satisfaction: A Cross-Cultural Review, 25-52, içinde: Enderson, N., Ones, D. Sinangil, H.K. ve Viswesvaran C., Handbook of Industrial, Work and Organizational Psychology: Organizational Psychology, V:2, Sage Publications Inc. California.

Kaçmaz, N. (2005). Tükenmişlik (Burnout) Sendromu [Burnout Syndrome]. İstanbul Tıp Fakültesi Dergisi, 68(1), 29-32.

Karaköse, T. ve Kocabaş, İ. (2006). Özel ve devlet okullarında öğretmenlerin beklentilerinin iş doyumu ve motivasyon üzerine etkileri [The effects of teachers' expectation on job satisfaction and motivation in private and public schools]. Ë̆itimde Kuram ve Uygulama, 2(1), 3-14.

Keser, A. (2005). İş doyumu ve yaşam doyumu ilişkisi: otomotiv sektöründe bir uygulama [Job satisfaction and life satisfaction relationship: an application in the automotive sector]. Çalışma ve Toplum, 4, 77-96.

Keskin, H., Akgün, A.E. ve Günsel, A. (2008). Örgütsel Adaletsizlik Kavramı, Boyutlarl ve Yönetimi [The Concept of Organizational Injustice, Dimensions and Management]. Özdevecioğlu, M ve Karadal, H., (eds.), Örgütsel Davranışta Seçme Konular: Organizasyonların Karanlık Yönleri ve Verimlilik Azaltıcı Davranışlar, 1. Bask1, Ankara, İlke Yayınevi.

Kılıç, Ö. S. (2011). İlköğretim okullarında görev yapan okul müdürü ve öğretmenlerin iş doyumu (Tokat ili örneği)[ The job satisfaction of school principals and teachers working in primary schools (Tokat province)]. Selçuk Üniversitesi, Eğitim Bilimleri Enstitüsü. Konya: Yayınlanmamış Yüksek Lisans Tezi.

Kinman, G.and Kinman, R. (2001). The role of motivation to learn in management education. The Journal of Workplace Learning, 13(4), 132-144.

Kurçer, M.A. (2005). Harran Üniversitesi Tıp Fakültesi Hekimlerinin İş Doyumu ve Tükenmişlik Düzeyleri [Job Satisfaction and Burnout Levels of Harran University Medical Faculty Physicians]. Harran Üniversitesi Tip Fakültesi Dergisi, 2(3),10-15.

Kuruoglu, M. (1995). Motivasyonunu Nümerik Analizi [Numerical Analysis of Motivation]. Yayınlanmamış yüksek lisans tezi, İstanbul Teknik Üniversitesi Fen Bilimleri Enstitüsü, İstanbul: Türkiye.

Maslach, C. \& Jackson, S. E. (1981). The measurement of experienced burnout. Journal of Occupational Behavior, 2, 99-113.

Maslach, C. and Jackson, S. E. (1986). Maslach Burnout Inventory Manual, 2nd Edition, Palo Alto, Consulting Psychologist Press.

Miner. J.B. (1992). Industrial/Organizational Psychology, New York, McGraw Hill.

Northcraft, G.B. ve Neale, M. A. (1990). Organizational Behavior: A Management Challenge, The Dryden Press, USA, Rinehart and Winston Inc.

Öğretmenlerinin Tükenmişlik Düzeylerinin Incelenmesi [Investigation of Burnout Levels of Teachers]. Retrieved 27.11.2017, from https://www.researchgate.net/publication/311849820_Ogretmenlerinin_Tukenmislik_ Duzeylerinin_Incelenmesi

Özsüer, S. (2016). Occupational motivation and job satisfaction of Turkish secondary school teachers of English and other subjects. Yeditepe University Educational Sciences Institute. İstanbul: Unprinted Master Thesis. 
Pascoe, C., Ali, I.M., \& Warne, L. (2002). Retrieved_18.12.2017, from http://proceedings.informingscience.org/152002Proceedings/papers/Pasco231YetAn.pdf

Perry, L.(1993). Effects of Inequity on Job Satisfaction and Self Evaluation in National Sample of AfricanAmerican Workers. Journal of Social Psychology, 133(4), 565-573.

Pillay, H., Goddard, R. \& Wilss, L. (2005). Well-being, burnout and competence: Implications for teachers. Australian Journal of Teacher Education, 30(2), 22-33.

Rowley, J. (1996). Motivation and academic staff in higher education. Quality Assurance in Education, 4(3), 1116.

Sabanc1, A. (1994). Ĕ̈itim Yönetiminde Çift Yönlü Illetişim Yönetilenleri Motivasyon ve İşdoyumu Bakımından Nasll Etkilemektedir? [How Does Two-Way Communication in Educational Administration Affect Managed Motivations and Job Satisfaction?] Yayınlanmamış doktora tezi, İnönü Üniversitesi Sosyal Bilimler Enstitüsü, Malatya: Türkiye.

Sağır, M. (2016). Yaşlanan iş gücünde iş doyumu: Millî Ĕ̆itim Bakanlı̆̆ örneği [Job satisfaction in aging work force: Ministry of National Education sample]. Çankaya Üniversitesi, Sosyal Bilimler Enstitüsü: Ankara: Yayınlanmamış Yüksek Lisans Tezi.

Sancar, İ. (1996). İşletmelerde Motivasyon ve İş Doyumu İlişkisi [Motivation and Job Satisfaction in Business]. Yayınlanmamış yüksek lisans tezi, Marmara Üniversitesi Sosyal Bilimler Enstitüsü, İstanbul: Türkiye.

Smith, M., Jaffe-Gill, E. \& Seggl, J. (2009). Retrieved 21.10.2017, from http://helpguideorg/mental/stress_signs.htm

Spector, P.E.(1997). Job Satisfaction: Application, Assessment, Cause and Consequences, USA, SAGE Publications.

Sun, H. Ö. (2002). İş Doyumu Üzerine Bir Araştırma [A Research on Job Satisfaction]. Uzmanlık Yeterlilik Tezi, Türkiye Cumhuriyeti Merkez Bankası Banknot Matbaası Genel Müdürlügü.

Telef, B., B. (2011). Öğretmenlerin öz-yeterlilikleri, iş doyumları, yaşam doyumları ve tükenmişliklerinin incelenmesi [Examination of teachers' self-sufficiency, job satisfaction, life satisfaction and burnout]. Elementary Education Online Dergisi, 10(1),91-108.

Türe, R. (1993). Yöneticilik ve Motivasyon [Management and Motivation]. İstanbul Üniversitesi Sosyal Bilimler Enstitüsü, İstanbul: Yayınlanmamış Yüksek Lisans Tezi.

Tüzemen, G. E. (2004). The overall op Satisfaction and the curriculum satisfaction of teachers at the second cycle of public elementary schools. Middle East Technical University Social Sciences Institute. Ankara: Unprinted Master Thesis.

Ünsal P., Türetgen İ. (2005). Bir İş Doyumu Ölçeği Geliştirme Çalışması [A Job Satisfaction Scale Development Study]. Yönetim, 16(51), 43-55. 